\title{
EXPRESSÃO DIFERENCIAL DE QUITINASES E CATALASES EM RAÍZES DE FEIJOEIRO COLONIZADAS POR Glomus clarum, NA PRESENÇA DE ÁCIDO SALICÍLICO OU FORMONONETINA
}

\section{Robinson Moresca de Andrade Biólogo}

Orientador: Prof. Dr. MARCIO R. LAMBAIS

Dissertação apresentada à Escola Superior de Agricultura "Luiz de Queiroz", Universidade de São Paulo, para obtenção do título de Mestre em Agronomia, Área de Concentração: Microbiologia Agrícola.

P IR A C I C A B A

Estado de São Paulo - Brasil

Dezembro - 2000 
Dados Internacionais de Catalogação na Publicação (CIP) DIVISĀO DE BIBLIOTECA E DOCUMENTAÇÃO - Campus "Luiz de Queiroz"/USP

Andrade, Robinson Moresca de

Expressão diferencial de quitinases e catalases em raízes de feijoeiro colonizadas por Glormus clarum, na presença de ácido salicilico ou formononetina / Robinson Moresca de Andrade. - - Piracicaba, 2000.

89 p. : il.

Dissertação (mestrado) - - Escola Superior de Agricultura Luiz de Queiroz, 2000. Bibliografia.

1. Ácido salicílico 2. Catalase 3. Feijão 4. Formononetina 5. Fungo micorrizico 6. Quitinase 7. Raiz 8. Simbiose I. Titulo

CDD 635.652

"Permitida a copia total ou parcial deste documento, desde que citada a fonte - 0 autor? 


\section{"A DEFESA DA NATUREZA COMEÇA PELA TERRA SEM TERRA NÃO HÁ PLANTA/SEM TERRA NÃO SE PLANTA PLANTE A REFORMA AGRÁRIA"}

Chico Mendes

Àqueles que acreditam em dias melhores, e a todos meus familiares, Dedico 


\section{ERRATA}

Na página $I I, 1^{\circ}$. parágrafo, onde se lê: "Alterações na expressão de outras proteínas...", leia-se: "Alterações na expressão de outras proteínas relacionadas ao sistema de defesa vegetal também têm sido observadas em micorrizas arbusculares. As atividades de catalases, por exemplo, podem ser induzidas em raizes colonizadas por fungos micorrízicos arbusculares. Compostos fenólicos podem ter efeito indutor ou inibidor do desenvolvimento de micorrizas arbusculares. $O$ ácido salicílico induz respostas de defesa em plantas e pode inibir o desenvolvimento de simbioses, enquanto que a formononetina pode favorecer seu desenvolvimento."

Na página II, $2^{\circ}$. parágrafo, onde se lê: "Neste trabalho foi avaliado o efeito do..." leia-se: "Neste trabalho foi avaliado o efeito do ácido salicílico (AS) e da formononetina (FOR) na colonização intrarradicular e nas atividades de quitinases e catalases em raízes de feijoeiro (Phaseolus vulgaris L. var. Carioca 80-SH) inoculadas com Glomus clarum, em çondições de baixo (20 mg P kg-1) ou alto nível de $\mathbf{P}$ (150 $\mathrm{mg} \mathrm{P} \mathrm{kg}^{-1}$ ). O AS foi aplicado no substrato a cada dois dias (3,62 $\mu \mathrm{mol}$ por vaso), e a FOR nas sementes, utilizando-se $7 \mathrm{~mL}$ de emulsão comercial (Mycoform, $120 \mathrm{mg}$ de formononetina $\mathrm{mL}^{-1}$ ) para 200 sementes. As plantas foram colhidas 4, 6 e 8 semanas após o plantio (SAP)."

Na página III, $1^{\circ}$. parágrafo, onde se lê: "Nesse experimento pode-se observar que a...", leia-se: "Pode-se observar que a alta concentração de $\mathbf{P}$ no substrato de cultivo inibiu a colonização micorrízica. As atividades de quitinases foram induzidas e as de catalases suprimidas em condições de alta disponibilidade de $\mathbf{P}$ no substrato de cultivo, na ausência de AS ou FOR, tanto em raízes não-micorrizadas quanto micorrizadas.

Na página III, $2^{\circ}$. parágrafo, onde se lê: "Os resultados obtidos, demonstraram que...", leiase: "A inoculação com o fungo micorrízico arbuscular resultou em indução das atividades de quitinases e catalases, principalmente no início do desenvolvimento da simbiose, sugerindo que quitinases e catalases podem estar envolvidas no controle da colonização intrarradicular.

Na página III, $3^{\circ}$. parágrafo, onde se lê: "Os resultados obtidos demonstram que...", leia-se: "Os resultados obtidos demonstram que, na concentração utilizada, o AS não interferiu na produção de biomassa vegetal e não afetou significativamente a colonização micorrizica. As atividades de quitinases, no geral, não foram afetadas pela aplicação de AS, exceto 8 $\mathrm{SAP}$, quando, na presença de AS e condições de alto $\mathrm{P}$, as atividades de quitinases foram induzidas. No início do desenvolvimento da micorriza (4 SAP), as atividades de catalases foram 2 vezes maiores do que em raízes não-micorrizadas, na ausência de AS, tanto em condições de baixo quanto alto $\mathbf{P}$. Os resultados obtidos neste experimento não corroboram resultados obtidos em experimentos anteriores, onde o $\mathrm{AS}$, normalmente, inibe as atividades de catalases, pelo menos in vitro."

Na página III, $4^{\circ}$. parágrafo, onde se lê: "A FOR não interferiu na produção...", leia-se: " A FOR não interferiu na produção de biomassa vegetal, mas induziu a colonização intrarradicular em condições de alta disponibilidade de $\mathrm{P}$. De maneira geral, a FOR não 
interferiu nas atividades de quitinases. No entanto, em raízes não-micorrizadas, na presença de FOR, as atividades de catalases foram induzidas até 200 vezes em condições de alto $P$, comparado com baixo $\mathrm{P}, 8 \mathrm{SAP}$. Em raízes micorrizadas, em condições de baixo $\mathrm{P}$, as atividades de catalases foram aproximadamente 66 vezes maiores do que em raízes nãomicorrizadas, 4 SAP. Esses dados sugerem que o efeito positivo da FOR sobre a colonização intrarradicular é maior em condições limitantes para o desenvolvimento da simbiose, e que a indução de catalases em raízes micorrizadas pode ser importante para $o$ controle do crescimento fúngico."

$\mathrm{Na}$ página IV, $1^{\circ}$. parágrafo, onde se lê: "It has been proposed that the differential expression...", leia-se: " It has been proposed that the differential expression of chitinases in roots has an important role in controlling intrarradical fungal growth in arbuscular mycorrhizae. Suppression of chitinase expression at the early stages of intrarradical colonization has been observed in several arbuscular mycorrhizae. Usually, suppression of chitinase expression is attenuated under unfavorable conditions to the development of the symbiosis, such as high phosphate concentrations, and the localized induction of specific chitinase isoforms in cells containing arbuscules can be observed. Differential expression of other defense related proteins, including catalase, has also been observed in arbuscular mycorrhizae at different phosphate conditions. It has been shown that catalase activities are induced in roots colonized by arbuscular mycorrhizal fungi and may be modulated by phosphate. Expression of defense related genes and intrarradical fungal growth may also be modulated by phenolic compounds, such as salicylic acid and formononetin. Salicylic acid induces defense responses in plants and may inhibit arbuscular mycorrhizae development, whereas formononetin may stimulate it.

Na página IV, $2^{\circ}$. parágrafo, onde se lê: "In this work the effects of salicylic acid...", leia-se: "In this work the effects of salicylic acid (SA) and formononetin (FOR) on the intrarradical fungal growth, chitinase and catalase activities activities in bean (Phaseolus vulgaris $\mathrm{L}$. var. Carioca 80-SH) roots inoculated with Glomus clarum, under low P (20 mg P kg ${ }^{-1}$ substrate) or high $P$ conditions (150 mg P kg-1 substrate) were evaluated. AS was applied every other day as an aqueous solution $(3,62 \mu \mathrm{mol}$ per $3 \mathrm{~kg}$ - pot) to the substrate. FOR was applied as an emulsion $\left(7 \mathrm{~mL}\right.$ of Mycoform, a commercial emulsion of formononetin $120 \mathrm{mg} \mathrm{mL}^{-1}$, per 200 seeds) onto the seeds. Plants were harvested 4, 6 and 8 weeks after planting (WAP)."

Na página $V, 1^{\circ}$. parágrafo, onde se lê: "From that experiment, it could be observed...", leiase: "High $\mathbf{P}$ concentration inhibited intrarradical fungal growth and altered chitinase and catalase expression in roots. In mycorrhizal as well as non-mycorrhizal roots, in the absence of SA or FOR, chitinase activities were induced at high $P$ conditions, compared to low $\mathrm{P}$ conditions, whereas catalase activities were suppressed."

Na página $V, 2^{\circ}$. parágrafo, onde se lê: "The results showed that the arbuscular...", leia-se: " Chitinase and catalase activities were also induced in mycorrhizal roots, compared to nonmycorrhizal controls, mostly at the early stages of symbioses development, suggesting that these proteins may be involved controlling intrarradical fungal growth." 
$\mathrm{Na}$ página $\mathrm{V}, 3^{\circ}$. parágrafo, onde se lê: "In the concentration used in this experiment...", leia-se: "At the concentration used in this experiment, SA had no effect on plant biomass production or intrarradical fungal growth. Chitinase activities, in general, were not affected by SA applications. However, at 8 WAP in the presence of SA and high P conditions, chitinase activities were induced. At the earliest time point (4 WAP), catalase activities were 2-fold higher in mycorrhizal than in non-mycomhizal roots grown in the absence of $\mathrm{SA}$, at low or high $\mathbf{P}$ conditions. Our results did not corroborate previous observations on the inhibitory effect of SA on catalase activities in vitro."

$\mathrm{Na}$ página $\mathrm{V}, 4^{\circ}$. parágrafo, onde se lê: "FOR also didn't interfere the shoot...", leia-se "FOR had no effect on plant biomass production and induced intrarradical fungal growth at high $\mathbf{P}$ conditions. In general, FOR had no effect on chitinase activities. However, in nonmycorrhizal roots in the presence of FOR, catalase activities were induced up to 200-fold at high $\mathbf{P}$ conditions, compared to low $\mathbf{P}$ conditions, at 8 WAP. In mycorrhizal roots at low $\mathrm{P}$ conditions, catalase activities were approximately 66-fold higher than in non-mycorrhizal controls, at 4 WAP. These data suggest that the stimulatory effect of FOR on the intrarradical fungal growth is higher at high $\mathrm{P}$ conditions and that catalase may play an important role in controlling mycorrhizae development."

Na página $V, 5^{\circ}$. parágrafo, onde se lê: "Differential expression of at least $6 \ldots$., leia-se: "Using SDS-PAGE, differential expression of at least 6 proteins was observed in the different treatments, suggesting that they may be involved in the regulation of the symbioses."

Na página $34,1^{\circ}$. parágrafo, onde se lê: "Porém, a produção de MSSR foi 1,7 vezes maior no tratamento inoculado..." leia-se: "Já, em condições de alto $\mathbf{P}$ e na presença de FOR, a produção de MSSR das plantas inoculadas com $G$. clarum foi 1,7 vezes maior do que das plantas não-inoculadas."

$\mathrm{Na}$ página $34,1^{\circ}$. parágrafo, onde se lê: "Na presença de FOR, os tratamentos inoculados...", leia-se: "Na presença de FOR e em condições de baixo $P$, os tratamentos inoculados com G. clarum apresentaram produção da MSSR 45\% maior do que os tratamentos não-inoculados. Porém, em condições de alto $P$, não houve efeito da micorrização sobre essa variável."

$\mathrm{Na}$ página $60,2^{\circ}$. parágrafo, onde se lê: "Em raízes não-micorrizadas e tratadas com FOR, as atividades...", leia-se: "Em raízes não-micorrizadas e tratadas com FOR, em condições de alto P, as atividades de catalases, 6 e 8 SAP, foram induzidas 5,8 e 200 vezes, respectivamente, comparado com condições de baixo $P$. Em raizes inoculadas com $G$. clarum, em condições de alto P, $6 \mathrm{SAP}$, as atividades de catalases foram 7,4 vezes maiores do que em condições de baixo P. Já, $8 \mathrm{SAP}$ e condições de alto $\mathrm{P}$, as atividades de catalases foram 43,7 vezes maiores do que em condições de baixo $P$." 
$\mathrm{Na}$ página $60,3^{\circ}$. parágrafo, onde se lê: "Entre os tratamento não-micorrizados e micorrizados...", leia-se: "Nos tratamento micorrizados, $4 \mathrm{SAP}$, as atividades de catalases foram 66,4 e 8,7 vezes maiores em condições de baixo e alto $P$, respectivamente, do que nos tratamentos não-micorrizados, na presença de FOR. Com 6 e 8 SAP, em condições de baixo $P$, as atividades de catalases foram suprimidas 1,4 vezes e induzidas 2,7 vezes em raízes micorrizadas, comparado com raízes não-micorrizadas, respectivamente. Já, em condições de alta disponibilidade de P, 6 e 8 SAP, houve uma supressão de 1,1 e 1,6 vezes, respectivamente."

Na página $60,4^{\circ}$. parágrafo, onde se lê: "Nos tratamentos micorrizados em condições de alto $\mathbf{P}$, as atividades de catalases...", leia-se: "Nos tratamentos micorrizados em condições de alto $P$, as atividades de catalases foram induzidas 1,1 vezes com 4 SAP, 1,9 vezes com 6 SAP e 121,9 vezes com 8 SAP, na presença de FOR."

Na página $66,3^{\circ}$. parágrafo, onde se lê "Tabela $2 "$ ", leia-se "Tabela $1 "$.

$\mathrm{Na}$ página 89, a Tabela "Caracterização isoenzimática de catalases em géis de poliacrilamida com aplicação de FOR", no tratamento Gc FOR AP, 6 SAP, onde se lê "4284531" leia-se "7284531".

Na seção REFERÊNCIAS BIBLIOGRÁFICAS, adicionar:

SCANDAlios, J.G. Oxygen stress and superoxide dismutases. Plant Physiology, v.101, n. 1, p. 7-12, 1993. 


\section{AGRADECIMENTOS}

Ao Prof. Marcio Rodrigues Lambais pela orientação, determinação, apoio e amizade.

Aos Profs. Murilo Mello e Sérgio F. Pascholati pelo apoio no início do curso.

À Coordenação do Curso de Pós-Graduação em Microbiologia Agrícola, ao Prof. Luiz Gonzaga do Prado Filho, coordenador na época de meu ingresso, e ao Prof. Flávio César A. Tavares, atual coordenador, pela amizade.

À CAPES, pelo auxílio financeiro.

Ao Prof. José Osvaldo Siqueira pelo fornecimento do composto "Formononetina".

Ao Serviço Social da ESALQ - USP pela moradia na Vila Estudantil.

Aos técnicos de laboratório Denise L.C. Mescolotti e Luis Fernando Baldesin.

Aos amigos Luiz Humberto Gomes, Keila M. R. Duarte e Salete A. Gaziola pela ajuda nos momentos difíceis e pela amizade conquistada.

A todos os alunos do laboratório de Microbiologia do Solo: Adriana, Ângela, Beatriz, Daniele, Denise, Elizabeth, Heron, Iara, Janaina, Jaqueline, Juliano, Júlio, Leandra, Maria Izabel, Marcelo, Renata, Sérgio, Simão, Taís e Winston.

Aos moradores da Casa 2 da Vila Estudantil (Aderbal, Antonio, Evandro, Jailson, João, Sebastião).

Em especial à Célia Regina e Marco A. Nogueira pelo apoio, correção gramatical e contribuição na discussão do texto.

Com carinho à Rosângela A. da Silva, por estar ao meu lado. 


\section{SUMÁRIO}

LISTA DE ABREVIATURAS I

RESUMO II

SUMMARY IV

1 INTRODUÇÃO 1

2 REVISÃO DE LITERATURA

2.1 Micorrizas arbusculares 3

2.2 Fósforo 4

2.3 O sistema de defesa vegetal e o controle do desenvolvimento de MAs

2.4 Compostos fenólicos e o desenvolvimento de MAs 8

3 METODOLOGIA 10

3.1 Instalação dos experimentos 10

3.2 Análises laboratoriais $\quad 12$

3.2.1 Matéria seca da parte aérea e sistema radicular $\quad 12$

3.2.2 Colonização micorrízica 12

3.2.3 Extração de proteinas 12

3.2.4 Atividades de quitinases $\quad 13$

3.2.5 Caracterização isoenzimática de quitinases em géis de poliacrilamida $\quad 14$

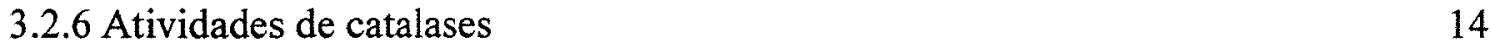

3.2.7 Caracterização isoenzimática de catalases em géis de poliacrilamida 15

3.2.8 Caracterização do perfil protéico em géis de poliacrilamida 15

3.3 Análise estatística 16

4 RESULTADOS E DISCUSSÃO

4.1 Crescimento vegetal na presença de ácido salicílico 17 
4.1.1 Parte aérea

4.1.2 Sistema radicular $\quad 24$

4.2 Crescimento vegetal na presença de formononetina 30

$\begin{array}{ll}\text { 4.2.1 Parte aérea } & 30\end{array}$

4.2.2 Sistema radicular $\quad 34$

4.3 Colonização intrarradicular 36

4.3.1 Efeito do ácido salicílico na colonização intrarradicular 36

4.3.2 Efeito da formononetina na colonização intrarradicular 37

4.4 Atividades e padrão isoenzimático de quitinases $\quad 40$

4.4.1 Efeito do ácido salicílico nas atividades de quitinases $\quad 40$

4.4.2 Efeito do ácido salicílico no padrão isoenzimático de quitinases

4.4.3 Efeito da formononetina nas atividades de quitinases $\quad 48$

4.4.4 Efeito da formononetina no padrão isoenzimático de quitinases 48

4.5 Atividades e padrão isoenzimático de catalases 54

4.5.1 Efeito do ácido salicílico nas atividades de catalases 54

4.5.2 Efeito do ácido salicílico no padrão isoenzimático de catalases 55

4.5.3 Efeito da formononetina nas atividades de catalases 59

4.5.4 Efeito da formononetina no padrão isoenzimático de catalases $\quad 60$

4.5.5 Efeito do ácido salicílico no perfil de proteínas totais 63

4.5.6 Efeito da formononetina no perfil de proteínas totais 66

5 CONCLUSÕES

REFERÊNCIAS BIBLIOGRÁFICAS

$\begin{array}{ll}\text { APENDICE } 1 & 82\end{array}$

APÊNDICE 2 


\section{LISTA DE ABREVIATURAS}

FMAs: fungos micorrízicos arbusculares

MAs: micorrizas arbusculares

AS: ácido salicílico

FOR: formononetina

P: fósforo

CAT: catalase

Ni: não-inoculado

Gc: Glomus clarum

MSPA: matéria seca da parte aérea

MSSR: matéria seca do sistema radicular

AP: alta concentração de $\mathrm{P}$

BP: baixa concentração de $\mathrm{P}$

SAP: semanas após o plantio

ABS: albumina de soro bovino

EAOs: espécies ativas de oxigênio

RSA: resistência sistêmica adquirida

MMA: massa molecular aparente

$\mathrm{AR}$ : abundância relativa 


\title{
EXPRESSÃO DIFERENCIAL DE QUITINASES E CATALASES EM RAÍZES DE FEIJOEIRO COLONIZADAS POR GIomus clarum, NA PRESENÇA DE ÁCIDO SALICÍLICO OU FORMONONETINA
}

\author{
Autor: Robinson Moresca de Andrade \\ Orientador: Prof. Dr. Marcio Rodrigues Lambais
}

\section{RESUMO}

Tem sido proposto que a expressão diferencial de isoformas de quitinases tem papel importante no controle da colonização fúngica intrarradicular em micorrizas arbusculares. Supressão da expressão de quitinases em condições favoráveis à colonização intrarradicular foi observado em várias micorrizas arbusculares. Normalmente, em condições desfavoráveis (por exemplo alto nível de fosfato) essa supressão é atenuada, e a indução localizada de isoformas específicas em células contendo arbúsculos pode ser observada. Alterações na expressão de outras proteínas relacionadas ao sistema de defesa vegetal também tem sido observada em micorrizas arbusculares. As atividades de catalases, por exemplo, podem ser induzidas em raízes colonizadas por fungos micorrízicos arbusculares. Compostos fenólicos podem ter efeito indutor ou inibidor do desenvolvimento de micorrizas arbusculares. $\mathrm{O}$ ácido salicílico induz respostas de defesa em plantas e pode inibir o desenvolvimento de micorrizas arbusculares. A formononetina é um flavonóide que pode favorecer o desenvolvimento de micorrizas arbusculares.

Neste trabalho foi avaliado o efeito do ácido salićlico e da formononetina na colonização intrarradicular e nas atividades de quitinases e catalases em raizes de feijoeiro (Phaseolus vulgaris L. var. Carioca $80-\mathrm{SH}$ ) inoculadas com Glomus clarum, em condições de baixo (20 $\mathrm{mg} \mathrm{P} \mathrm{kg}^{-1}$ ) ou alto nível de P (150 mg P kg${ }^{1}$ ). O AS foi aplicado no substrato a cada dois dias (3,62 $\mu \mathrm{mol}$ por vaso), e a FOR nas sementes, utilizando-se $7 \mathrm{~mL}$ de emulsão comercial (Mycoform, $120 \mathrm{mg}$ de 
formononetina $\mathrm{mL}^{-1}$ ) para 200 sementes. As plantas foram colhidas 4, 6 e 8 semanas após o plantio.

Nesse experimento pode-se observar que a colonização micorrizica foi inibida em condições de alta concentração de $\mathrm{P}$ no substrato, e no geral, as atividades de catalases e quitinases foram induzidas em condições de alta concentração de fósforo no substrato de cultivo, e em raízes colonizadas por G. clarum.

Os resultados obtidos, demonstraram que o fungo micorrízico arbuscular induziu a produção de matéria vegetal, as atividades de quitinases e catalases. Os dados sugerem que quitinases e catalases podem estar envolvidas no controle da colonização intrarradicular.

Os resultados obtidos demonstram que, na concentração utilizada, o ácido salicílico não interferiu na produção da matéria seca da parte aérea e do sistema radicular, não inibiu a colonização micorrízica em concentrações de baixo fósforo, e induziu as atividades de catalases.

A FOR não interferiu na produção de MSPA e MSSR, e induziu a colonização intrarradicular em condições de alta disponibilidade de P. De maneira geral, a FOR induziu as atividades de catalases, principalmente em condições de alto $P$.

Expressão diferencial de pelo menos 6 proteínas foi observada nos diferentes tratamentos, sugerindo que elas podem ter papel relevante no controle do desenvolvimento de micorrizas arbusculares. 


\title{
DIFFERENCIAL EXPRESSION OF QUITINASES AND CATALASES IN BEANS ROOTS COLONIZED BY Glomus clarum, IN PRESENCE OF SALICYLIC ACID OR FORMONONETIN
}

\author{
Author: Robinson Moresca of Andrade \\ Adviser: Prof. Dr. Marcio Rodrigues Lambais
}

\section{SUMMARY}

It has been proposed that the differential expression of chitinases isoforms has important role in the control of the intraradical colonization in fungal arbuscular mycorrhizal symbiosis. Suppression of the chitinases expression in favorable conditions to the intraradical colonization was observed in several arbuscular mycorrhiza. Usually, under unfavorable conditions (such as high level of phosphate) the suppression is attenuated, and the localized induction of specific isoforms in cells containing arbuscules can be observed. Alterations in the expression of another proteins related to the plant defense system have also been observed in arbuscular mycorrhiza. Catalases activities, for example, can be induced in roosts colonized by arbuscular mycorrhiza fungi. Phenolic compounds can have inductor or inhibitor effect on the development of arbuscular mycorrhiza. Salicylic acid induces defense reactions in plants and it can inhibit the development of arbuscular mycorrhiza. The formononetin is a isoflavonoid that can stimulate the arbuscular mycorrhiza development.

In this work the salicylic acid and formononetin effects on the intraradical colonization and on the chitinases activities and catalases in bean roosts (Phaseolus vulgaris L. var. Carioca 80-SH) inoculated with Glomus clarum, in low $\mathrm{P}$ conditions (20 mg P kg$\left.{ }^{-1}\right)$ or high P level $\left(150 \mathrm{mg} \mathrm{P} \mathrm{kg}^{-1}\right)$ were evaluated. The AS was applied every day in the substratum $(3,62 \mu \mathrm{mol}$ for vase), while FOR was applied in the seeds, by using $7 \mathrm{~mL}$ of commercial emulsion (Mycoform, $120 \mathrm{mg}$ of formononetin $\mathrm{mL}^{-}$ ${ }^{1}$ ) for 200 seeds. Plants were harvested 4, 6 and 8 weeks after sowing. 
From that experiment, it could be observed that the mycorrhizal colonization was inhibited in high P concentration in the substratum, and in the general, catalases activities and chitinases were induced in conditions of high $\mathrm{P}$ concentration in the cultivation substratum, and in roosts colonized by G. clarum as well.

The results showed that the arbuscular mycorrhizal fungi induced the production of vegetable matter, the chitinase activities and catalases. The data also suggest that chitinases and catalases can be involved in the control of the intraradical colonization.

In the concentration used in this experiment, the salicylic acid didn't interfere on the shoot and root dry weight, and didn't inhibit the mycorrhiza colonization in low $\mathrm{P}$ concentration, and it induced the catalases activities.

FOR also didn't interfere the shoot and root dry weight, but it induced the intraradical colonization under high $\mathrm{P}$ conditions. In a general way, FOR induced catalases activities, mainly under high $\mathrm{P}$ conditions.

Differential expression of at least 6 proteins were observed in the different treatments, suggesting that they can have important role in the development control of the arbuscular mycorrhiza. 


\section{INTRODUÇÃO}

As micorrizas são as simbioses entre plantas e microrganismos mais antigas que se conhece. Ocorrências fósseis e dados de sequências de DNA dos fungos micorrízicos sugerem que as micorrizas tiveram sua origem entre 350 e 460 milhões de anos atrás, quando as plantas começaram a colonizar os ambientes terrestres (Remy et al., 1994).

O termo "micorriza" foi utilizado pela primeira vez por Frank (1885), para descrever a simbiose entre fungos e raízes de plantas. As micorrizas podem ser classificadas, conforme suas características morfológicas, em 3 grupos: ectomicorrizas, endomicorrizas e ectendomicorrizas. Do ponto de vista agronômico, as endomicorrizas arbusculares, são as mais importantes, pois ocorrem na maioria das plantas cultivadas. Essas micorrizas são formadas por fungos da ordem Glomales (Zigomicetos), os quais são simbiontes obrigatórios. No tecido radicular esses fungos crescem tanto inter quanto intracelularmente, formando estruturas intracelulares típicas chamadas arbúsculos.

Os esporos de fungos micorrízicos arbusculares (FMAs) possuem diâmetro variando de aproximadamente $20 \mathrm{a} 600 \mu \mathrm{m}$, altas concentrações de lipídeos e vários núcleos. Tem sido relatado que Gigaspora margarita possui cerca de 20000 núcleos, enquanto espécies do gênero Glomus possuem entre 5000 a 9000 núcleos (Burgraaf \& Beringer, 1989; Vieira \& Glenn, 1990).

$\mathrm{O}$ desenvolvimento das micorrizas arbusculares (MAs) exige condições ambientais favoráveis, como $\mathrm{pH}$, temperatura e baixa disponibilidade de 
fósforo (P). Metais como $\mathrm{Al}, \mathrm{Zn}, \mathrm{Mn}$ e Cd podem ser tóxicos, inibindo a germinação dos esporos e/ou o desenvolvimento intrarradicular (Lambais \& Cardoso, 1989; Nogueira, 1996).

Os mecanismos que regulam o desenvolvimento da simbiose não são conhecidos. Com base na expressão diferencial de quitinases, $\beta-1,3$-glucanases, proteínas ricas em hidroxiprolina e enzimas envolvidas na síntese de fitoalexinas isoflavonóides, acredita-se que proteínas de defesa vegetal estejam envolvidas nesse processo (Lambais \& Mehdy, 1998). É possível, também, que a regulação diferencial de genes de defesa em MAs envolva a geração e degradação de radicais livres de oxigênio em células contendo arbúsculos e/ou em suas proximidades.

Certos compostos fenólicos, como o ácido salicílico (AS), podem induzir respostas de defesa e inibir o desenvolvimento de MAs (Costa et al., 2000). Por outro lado, outros compostos fenólicos, como a formononetina, podem favorecer o desenvolvimento de MAs, principalmente em condições desfavoráveis, como por exemplo em condições de alto P (Silva Júnior \& Siqueira, 1998). Os mecanismos de desenvolvimento da simbiose pelos quais os compostos fenólicos regulam o desenvolvimento de MAs é desconhecido. Hipoteticamente, compostos fenólicos poderiam alterar o estado redox das células vegetais e a expressão de genes de defesa envolvidos no controle do desenvolvimento de MAs.

O objetivo desse trabalho foi avaliar as atividades de quitinases (enzimas indicadoras de alterações da expressão de genes de defesa vegetal) e catalases (enzimas indicadoras de alterações da expressão de genes envolvidos na degradação de espécies ativas de oxigênio) durante o desenvolvimento de MAs, em raízes de feijoeiro colonizadas por Glomus clarum e raízes não-colonizadas, em condições de baixa disponibilidade de $\mathrm{P}$ (20 mg $\mathrm{P} \mathrm{kg}^{-1}$ de substrato) ou alta disponibilidade de $\mathrm{P}$ (150 $\mathrm{mg} \mathrm{P} \mathrm{kg}^{-1}$ de substrato), na presença de um composto fenólico indutor de respostas de defesa, o ácido salicílico, e de um estimulador de MAs, a formononetina. 


\section{REVISÃO DE LITERATURA}

\subsection{Micorrizas arbusculares}

As MAs são associações mutualísticas entre raízes de plantas vasculares e fungos específicos (Glomales, Zygomicetos). A natureza mutualística dessa simbiose baseia-se no fato de que a planta fornece substrato energético ao fungo (carboidratos), que por sua vez absorve nutrientes da solução do solo, principalmente o $\mathrm{P}$, e os transfere para a planta. As MAs recebem este nome por apresentarem uma característica estrutural típica chamada arbúsculo.

Os FMAs surgiram há aproximadamente 350-460 milhões de anos, com base em evidências fósseis e sequências do DNA-ribossômico 18S (Simon et al., 1993; Remy et al.,1994). Podem ser classificados em 6 gêneros: Glomus, Sclerocystis, Gigaspora, Scutellospora, Acaulospora e Entrophospora (Subba, 1995; INVAM, 2000). Aproximadamente 160 espécies já foram descritas (INVAM, 2000).

Os FMAs podem colonizar os espaços entre as células do tecido cortical das raizes e o interior de algumas dessas células, onde as hifas podem se diferenciar em arbúsculos. Normalmente, os vasos condutores e as regiões meristemáticas não são colonizadas (Ingold \& Hudson, 1993). Além do micélio intrarradicular, as MAs apresentam também micélio extrarradicular, o qual é responsável pela absorção de nutrientes da solução do solo e sua translocação para a planta (Ingold \& Hudson, 1993).

O metabolismo dos FMAs é dependente de C-orgânico proveniente da fotossíntese. De $4 \%$ a $20 \%$ do carbono fixado pela fotossíntese é transferido para 
o micélio fúngico e usado para produção de estruturas vegetativas, reprodutivas e absorção de nutrientes (Smith \& Read, 1997).

A colonização micorrízica e a eficiência simbiótica são altamente reguladas pela concentração de $\mathrm{P}$ na planta. Altos níveis de $\mathrm{P}$ inibem o desenvolvimento dos FMAs nas raízes (Koide \& Li, 1990). Os mecanismos moleculares dessa regulação não são conhecidos. Em altos níveis de $\mathrm{P}$ as atividades de quitinases são mais elevadas do que em baixos níveis de $\mathrm{P}$, e a supressão de quitinases, normalmente observada durante os estágios iniciais do desenvolvimento de MAs, é atenuada (Spanu et al., 1989; Lambais \& Mehdy, 1993), sugerindo que o $P$ pode estar envolvido no controle da expressão de genes de defesa importantes para o controle do desenvolvimento das MAs.

\subsection{Fósforo}

$\mathrm{O} \mathrm{P}$ é um dos mais importantes e limitantes macronutrientes vegetais, representando aproximadamente $0,2 \%$ da matéria seca das plantas. É essencial para a síntese de ácidos nucléicos, fosfolipídeos e ATP. Está envolvido também na regulação das várias vias metabólicas (Schachtman et al., 1998).

Nas situações em que a concentração e mobilidade do $P$ no solo são baixas, a sua absorção é favorecida nas plantas associadas aos FMAs. Por sua vez, a disponibilidade do $\mathrm{P}$ exerce importante papel no controle da intensidade de colonização e do efeito da simbiose sobre a planta. Geralmente, baixas concentrações de $\mathrm{P}$ são favoráveis ao desenvolvimento das MAs. Condições ótimas variam de $10 \mathrm{a}$ $100 \mathrm{mg} \mathrm{kg}^{-1}$ de $\mathrm{P}$ disponível no solo, caracterizando um balanço delicado entre a disponibilidade de $\mathrm{P}$, o desenvolvimento do fungo nas raízes e a resposta da planta à simbiose. Dependendo da concentração de $\mathrm{P}$ na planta, a simbiose pode ter natureza mutualística, neutralística ou parasítica (Siqueira \& Colozzi-Filho, 1986; Koide \& Li, 1990). 
Tem sido sugerido que o aumento do $\mathrm{P}$ na planta resulta em diminuição da permeabilidade da membrana plasmática e consequente diminuição da exsudação de compostos necessários para a formação das MAs (Ratnayake et al. 1978). Já em baixas concentrações de $P$, ocorreria alta exsudação de aminoácidos e açúcares, estimulando o crescimento dos fungos micorrízicos e a colonização intrarradicular. Alternativamente, altos níveis de $\mathrm{P}$ poderia induzir o acúmulo de sacarose nas raízes e inibir o desenvolvimento dos FMAs (Siqueira, 1983).

Lambais \& Medhy (1993) demonstraram que, em condições de alto $P$, a supressão de mRNA codoficando quitinases em raízes de feijoeiro inoculadas com $G$. clarum é atenuada e que isoformas específicas de quitinases e $\beta-1,3$ glucanases apresentam indução localizada em células contendo arbúsculos e suas proximidades.

Altos níveis de $\mathrm{P}$ poderiam, também, inibir a síntese de fatores responsáveis pela indução da formação de apressórios funcionais (Lambais, 1996). Normalmente, o número de apressórios é reduzido em condições de altas disponibilidades de $\mathrm{P}$ e um grande número de dilatações nas hifas são observados (Lambais, 1996). Assim, a deficiência no reconhecimento entre os simbiontes poderia explicar os baixos níveis de colonização intrarradicular nessas condições.

\subsection{O sistema de defesa vegetal e o controle do desenvolvimento de MAs}

O processo de infeç̧ão de um fungo patogênico tem início com a adesão dos esporos à superfície da planta hospedeira, seguida da diferenciação do tubo germinativo em apressório, ocasionando a penetração. No entanto, o processo de sinalização bioquímica pode ter início antes mesmo de um contato físico entre o fungo e a planta hospedeira (Leite et al., 1997). Em interações incompatíveis, o reconhecimento de sinais moleculares pela planta leva à rápida indução de genes de defesa vegetal (Pascholati \& Leite, 1995). 
Os vegetais podem apresentar dois tipos de mecanismos de defesa: pré-formado (estruturas presentes nas plantas) e pós-formado (produzidos ou ativados em resposta ao processo de infecção) (Pascholati \& Leite, 1995). Os genes envolvidos no sistema de defesa vegetal são, normalmente, induzidos por sinais moleculares, tais como: espécies ativas de oxigênio (EAOs), etileno, ácido salicílico, entre outros (Agrios, 1997).

As EAOs produzidas durante o metabolismo celular em plantas sob condições de estresse, são altamente tóxicas, podendo reagir com ácidos graxos insaturados das membranas celulares e alterar sua funcionalidade, afetar a atividade respiratória em mitocôndrias, diminuir a pigmentação e a capacidade de fixação de carbono em cloroplastos. Em interações planta-patógenos, as EAOs podem se acumular em resposta à infecção, resultando em uma reação de hipersensibilidade, com indução de apoptose e da resistência sistêmica adquirida (RSA) (Scandalios, 1993). Mehdy (1994) relata que, em suspensão de células de Phaseolus vulgaris tratadas com $\mathrm{H}_{2} \mathrm{O}_{2}$, ocorre indução e acúmulo de mRNAs codificando enzimas envolvidas na biossíntese de fitoalexinas e de endoquitinases, de maneira similar à aplicação de elicitores derivados da parede celular fúngica. $\mathrm{O}$ acúmulo de EAOs em células vegetais pode ser também induzido pelo AS. Tem sido demonstrado que o AS se liga à catalase, inibindo sua atividade e induzindo o acúmulo de $\mathrm{H}_{2} \mathrm{O}_{2}$ nas células (Ryals et al., 1996; Janda et al.,1999), o que resulta em respostas de defesa vegetal.

As catalases (EC 1.11.1.6) são enzimas antioxidantes, presentes em todos os organismos aeróbios, tendo um importante papel na degradação do $\mathrm{H}_{2} \mathrm{O}_{2}$, um intermediário tóxico do metabolismo do oxigênio, que em vegetais é produzido durante a fotorrespiração e a oxidação de ácidos graxos.

A expressão de catalases varia em diferentes condições ambientais. Em brotos de cevada, isoformas de catalases são diferencialmente induzidas na ausência ou presença de luz (Holtman et al., 1997). Em milho, isoformas de catalases apresentam expressão diferencial em resposta a estresse térmico durante o desenvolvimento (Auh \& Scandalios, 1997). 
A ocorrência de isoformas de catalases em organelas e/ou tecido específico tem sido reportada. Em Arabidopsis, foram detectadas seis isoformas em flores e folhas, e duas em sementes e raízes (Frugoli et al., 1996); duas em mamona (Ota et al., 1992); três em tabaco (Havir \& McHale, 1987); doze em cotilédones de mostarda (Drumm \& Schopfer, 1974); e cinco em embriões de milho (Williamson \& Scandalios, 1993). Em raizes de feijoeiros micorrizadas, uma única isoforma de catalase foi observada, a qual pode estar envolvida no controle do crescimento intrarradicular de FMAs em diferentes concentrações de P no solo (Rios-Riuz, 1998).

Em MAs, apesar da extensiva colonização das raízes pelos fungos, não há desenvolvimento de sintomas evidentes de repostas de hipersensibilidade (Gianinazzi, 1991). No entanto, regulação diferencial de genes/proteínas envolvidas na defesa vegetal contra patógenos tem sido observada, sugerindo que o processo de colonização intrarradicular pode ser controlado pelo sistema de defesa vegetal.

Os genes envolvidos na defesa vegetal e modulados durante a formação de MAs, podem ser divididos em quatro grupos (Lambais, 1996):

a) Genes envolvidos na via biossintética de fitoalexinas isoflavonóides: fenilalanina amônia-liase, chalcona sintase, chalcona isomerase e isoflavona redutase.

b) Genes codificando hidrolases com atividades antimicrobianas: quitinases e $\beta$-1,3-glucanases.

c) Genes codificando proteínas envolvidas no aumento da rigidez da parede celular vegetal: peroxidases e proteinas ricas em hidroxiprolina (HRGPs).

d) Genes codificando proteínas relacionadas à patogênese (PRproteínas): PR- $b_{1}$ e PR1.

Dentre esses genes, aqueles codificando quitinases talvez sejam os de maior importância no controle da colonização intrarradicular em MAs (Lambais, 1996).

As quitinases (EC 3.2.1.14) são enzimas hidroliticas que degradam polimeros de $\mathrm{N}$-acetil-glicosamina (quitina), abundantes na parede celular de vários fungos (Ancillo et al., 1999). Em plantas, as isoformas ácidas ocorrem, normalmente, 
nos espaços intercelulares $\mathrm{e}$ as básicas podem ser localizadas nos vacúolos (Pascholati \& Leite, 1995). As atividades de quitinases em plantas podem ser induzidas pela infecção por fungos (Neuhaus et al., 1991), bactérias (Guzzo \& Martins, 1996) e vírus (Bol \& Linthorst, 1990). Podem ser induzidas também por etileno (Mauch \& Staehelin, 1989) e AS (Chen et al., 1993).

Em MAs, quitinases básicas apresentam indução transiente, na fase inicial do processo de colonização das raízes pelos FMAs, seguida de supressão (David et al.,1998; Lambais \& Mehdy, 1993, 1996;Volpin et al., 1994; Spanu et al., 1989).

Lambais \& Mehdy (1995) sugerem que quitinases e $\beta-1,3-$ glucanases podem estar envolvidas no controle da colonização fúngica intrarradicular em MAs. A expressão de quitinases em raízes de soja colonizadas por um isolado mais infectivo de $G$. intrarradices foi atenuada em relação às raízes colonizadas por um isolado menos infectivo (Lambais \& Mehdy, 1996). Adicionalmente, em condições de alto $\mathrm{P}$, a expressão de uma quitinase ácida é induzida em células contendo arbúsculos e/ou sua vizinhança (Lambais \& Mehdy, 1998).

Os FMAs poderiam causar mudanças no balanço hormonal em raízes, modulando a expressão de genes de defesa e genes específicos relacionados à simbiose. Tem sido observado que os níveis de auxinas, citocininas, ácido abscísico e etileno são alterados em raízes micorrizadas, bem como o balanço de fito-hormônios. (Lambais \& Mehdy, 1995).

\subsection{Compostos fenólicos e o desenvolvimento de MAs}

As plantas sintetizam, acumulam e liberam através de exsudações, grande variedade de substâncias orgânicas, dentre as quais destacam-se os flavonóides. Esses representam importante classe de metabólitos secundários das plantas, estando envolvidos no estabelecimento e funcionamento de relações patogênicas e mutualisticas, atuando nos mecanismos de defesa contra invasores ou 
como sinais moleculares. Os compostos fenólicos podem afetar o metabolismo, funções, crescimento e desenvolvimento vegetal. Além disso, exibem atividade antimicrobiana contra patógenos de plantas e uma variedade de outros microrganismos do solo, afetando a germinação de esporos e crescimento micelial (Siqueira et al., 1991).

Rao et al. (1997) investigaram o envolvimento do AS na indução das reações de defesa da planta e a sua relação com o aumento da concentração de $\mathrm{H}_{2} \mathrm{O}_{2}$. Os autores observaram a redução das atividades de catalases e ascorbato peroxidase, elém do desenvolvimento de uma resposta de hipersensibilidade. Com o aumento dos níveis de AS no tecido vegetal ocorrem concomitantes aumentos das concentrações de EAOs, as quais podem alterar o estado de oxidação dos fatores de transcrição e ativar vários genes de defesa (Agrios, 1997; Mehdy, 1994).

$O$ efeito do AS no desenvolvimento das MAs não é conhecido. No entanto, se o AS está envolvido na indução das atividades de quitinases, e se essas enzimas estão envolvidas no controle do crescimento fúngico intrarradicular, é provável que o AS iniba a formação de MAs, similarmente à inibição que se observa em plantas com altas concentrações de $P$.

Costa et al. (2000) descreveram em seus trabalhos que o AS inibiu a colonização micorrízica intrarradicular, de forma semelhante a condições de alta concentração de $\mathrm{P}$, mas sugeriram que os mecanismos de regulação de quitinases pelo AS e pela disponibilidade de $P$ não são os mesmos.

Diversos estudos demonstraram a influência de vários flavonóides sobre a germinação dos esporos, crescimento do tubo germinativo e estabelecimento da simbiose endomicorrízica (Gianinazzi-Pearson et al., 1989; Tsai \& Phillips, 1991; Lambais, 1996). Entre os compostos estudados, destaca-se o isoflavonóide formononetina (FOR), identificado como fator estimulante dos FMAs. Esse composto pode ser obtido de exsudatos radiculares de plantas de trevo branco, cultivadas sob condições de deficiência de fósforo, cuja aplicação estimula a colonização micorrízica em diversas culturas (Nair et al., 1991; Siqueira et al., 1991). 


\section{METODOLOGIA}

\subsection{Instalação dos experimentos}

Os experimentos foram conduzidos em vasos, em condições de casa-de-vegetação, nas dependências do Departamento de Solos e Nutrição de Plantas da Escola Superior de Agricultura "Luiz de Queiroz"/USP.

Foram realizados experimentos para se avaliar o efeito de dois compostos fenólicos (AS e FOR) no desenvolvimento de MAs e na expressão de quitinases e catalases em raízes de feijoeiro, sob condições de baixa e alta concentração de $\mathrm{P}$ no substrato de cultivo.

As plantas foram cultivadas em uma mistura de areia lavada e vermiculita, na proporção de $3: 1(\mathrm{~V} / \mathrm{V})$, esterilizada a $121^{\circ} \mathrm{C}$ (a $1 \mathrm{~atm}$ de pressão) por 2 horas. Sementes de feijão (Phaseolus vulgaris L. var. Carioca 80-SH), cedidas pelo Instituto Agronômico de Campinas, foram desinfestadas superficialmente com solução comercial de hipoclorito de sódio $2 \%$, por $10 \mathrm{~min}$, e lavadas com $\mathrm{H}_{2} \mathrm{O}$ destilada esterilizada. A semeadura foi feita diretamente nos vasos contendo $1,5 \mathrm{Kg}$ de substrato. Dois dias antes do plantio, foram adicionados, por kg de substrato, 20 mg ou $150 \mathrm{mg}$ de $\mathrm{P}$, na forma de $\mathrm{KH}_{2} \mathrm{PO}_{4} ; 27 \mathrm{mg}$ de $\mathrm{N}$, na forma de $\mathrm{NH}_{4} \mathrm{NO}_{3} ; 150$ $\mathrm{mg}$ de $\mathrm{K}$, na forma de $\mathrm{KCl} ; 50 \mathrm{mg}$ de $\mathrm{Ca}$, na forma de $\mathrm{CaCl}_{2} ; 35 \mathrm{mg}$ de $\mathrm{Mg}$, na forma de $\mathrm{MgSO}_{4} .7 \mathrm{H}_{2} \mathrm{O}$. Os micronutrientes foram fornecidos na dose de $0,5 \mathrm{~mL}$ de FeEDTA e $0,5 \mathrm{~mL}$ da solução de micronutrientes de Hoagland por vaso. Aos 15 e 30 dias após o plantio, foram feitas adubações complementares com $27 \mathrm{mg}$ de $\mathrm{N}$ por $\mathrm{kg}$ de substrato, na forma de $\mathrm{NH}_{4} \mathrm{NO}_{3}$. 
No momento do plantio, foram adicionados $10 \mathrm{~g}$ de inóculo do FMA Glomus clarum por vaso. O inóculo foi obtido de vasos de multiplicação com Brachiaria decumbens, e consistia de uma mistura de solo, esporos e fragmentos de raizes colonizadas. $O$ tratamento controle sem FMA recebeu a mesma quantidade de amostras de solo proveniente de vasos com Brachiaria decumbens não-micorrizada.

O AS (orto-hidroxibenzóico) foi aplicado no substrato de cultivo na forma de solução ( $5 \mathrm{~mL}$ por vaso de uma solução $1 \mathrm{~g}$ de $\mathrm{AS} \mathrm{L}^{-1}, \mathrm{pH} \mathrm{7,0)} \mathrm{em} \mathrm{dias}$ alternados, a partir da segunda semana após o plantio (SAP). As plantas receberam: $25,34 \mu \mathrm{mol} \mathrm{de} \mathrm{AS} \mathrm{kg}^{-1}$ de substrato, até a primeira amostragem (4 SAP); 50,68 $\mu \mathrm{mol}$ de AS $\mathrm{kg}^{-1}$ de substrato, até a segunda amostragem (6 SAP); e 76,02 $\mu$ mol de $\mathrm{AS} \mathrm{kg}^{-1}$ de substrato, até a terceira amostragem (8 SAP). A concentração de AS utilizada foi definida com base no trabalho de Costa et al. (2000).

A FOR (4'-metoxi, 7-hidroxi isoflavona) foi aplicada diretamente nas sementes, na forma de emulsão comercial (Mycoform, $120 \mathrm{mg}$ de formononetina $\mathrm{mL}^{-1}$ ), utilizando-se $7 \mathrm{~mL}$ da emulsão para 200 sementes.

Com 4, 6 e $8 \mathrm{SAP}$, as plantas foram colhidas e as raizes lavadas com $\mathrm{H}_{2} \mathrm{O}$ destilada. $\mathrm{O}$ terço médio do sistema radicular foi amostrado para a avaliação do nível de colonização micorrizica intrarradicular. $\mathrm{O}$ restante do sistema radicular foi congelado em nitrogênio líquido e armazenado $\mathrm{a}-80^{\circ} \mathrm{C}$.

$\mathrm{O}$ delineamento experimental foi inteiramente casualizado, em esquema fatorial $2 \times 2 \times 2$, sendo 2 níveis do fator "doses de fósforo" (baixo P, 20 $\mathrm{mg} \mathrm{P} \mathrm{kg}{ }^{-1}$ e alto $\mathrm{P}, 150 \mathrm{mg} \mathrm{P} \mathrm{kg}^{-1}$ ), 2 níveis do fator "fungo" (controle não-inoculado e Glomus clarum), 2 níveis do fator "modulador" (controle sem fenólico e com modulador, AS ou FOR). O experimento foi avaliado em 3 épocas (4, 6 e 8 SAP), analisadas separadamente e não consideradas como fatores experimentais. Foram utilizadas 4 repetições por tratamento, perfazendo 96 vasos por experimento. 


\subsection{Análises laboratoriais}

\subsubsection{Matéria seca da parte aérea e sistema radicular}

Em cada época de colheita, separou-se a parte aérea do sistema radicular das plantas. $\mathrm{O}$ sistema radicular foi lavado com $\mathrm{H}_{2} \mathrm{O}$ destilada. Uma subamostra de aproximadamente $10 \mathrm{~g}$ foi removida para determinação da matéria seca, $\mathrm{e}$ o restante foi rapidamente congelado em nitrogênio líquido e armazenado a $-80^{\circ} \mathrm{C}$. As raízes e a parte aérea das plantas foram embaladas em sacos de papel e secas à $65^{\circ} \mathrm{C}$ até massa constante.

\subsubsection{Colonização micorrízica}

Após a determinação da massa de matéria seca do sistema radicular (MSSR), as raizes foram re-hidratadas com $\mathrm{H}_{2} \mathrm{O}$ destilada por $24 \mathrm{~h}$ e coloridas segundo Phillips \& Hayman (1970). As raízes foram tratadas com solução de KOH $10 \%$ em banho-maria a $90^{\circ} \mathrm{C}$ por 50 min, lavadas em $\mathrm{H}_{2} \mathrm{O}$ corrente, clarificadas com solução de $\mathrm{HCl} 1 \%$ por alguns segundos e coloridas com solução de azul de tripano em lactoglicerol por 5 a 10 min em banho-maria a $90^{\circ} \mathrm{C}$.

A determinação da porcentagem de colonização intrarradicular foi feita por microscopia óptica, utilizando-se uma placa reticulada, conforme descrito por Giovannetti \& Mosse (1980).

\subsubsection{Extração de proteínas}

Das raizes preservadas a $-80^{\circ} \mathrm{C}, 2 \mathrm{~g}$ foram macerados em nitrogênio líquido e homogeneizados em $6 \mathrm{~mL}$ de tampão de extração contendo citrato de sódio 0,1 
M (pH 5,0); EDTA 5 mM; PMSF (parametilsulfonilfluoreto) $1 \mathrm{mM}$ e $\beta$-mercaptoetanol 0,01 $\mathrm{mM}$ por $2 \mathrm{~min}$, utilizando-se um homogeneizador MA 102 (Marconi), em média rotação. Em seguida, o homogeneizado foi centrifugado a $20.000 \mathrm{~g}$, por $20 \min$ a $4{ }^{\circ} \mathrm{C}$. O sobrenadante recuperado foi mantido a $-20{ }^{\circ} \mathrm{C}$ para determinação das atividades de quitinases e catalases em solução.

Para determinação das atividades de quitinases e catalases em géis de poliacrilamida e análise do perfil de proteínas, as raízes $(1 \mathrm{~g})$ foram maceradas em nitrogênio líquido e homogeneizadas em tampão Tris- $\mathrm{HCl} 0,1 \mathrm{M}(\mathrm{pH} 8,0)$. $\mathrm{O}$ homogeneizado foi centrifugado e o sobrenadante armazenado a $-80^{\circ} \mathrm{C}$.

A determinação da concentração de proteínas nos extratos foi feita pelo método de Bradford (1976), utilizando-se microplacas. Para essa determinação, diluiram-se $300 \mu \mathrm{L}$ do extrato bruto em $300 \mu \mathrm{L}$ de tampão de extração. Distribuiram-se $200 \mu \mathrm{L}$ do diluído em microplaca, adicionaram-se $50 \mu \mathrm{L}$ de reagente de Bradford concentrado (BioRad), e em seguida a absorbância a $595 \mathrm{~nm}$ foi determinada em espectrofotômetro de microplacas (BioRad). A concentração de proteínas no extrato bruto foi determinada utilizando-se curva padrão com albumina de soro bovino (ASB). Foram utilizadas 3 repetições para cada determinação. A concentração de proteínas foi expressa em equivalentes $\mu \mathrm{g}$ de ASB por $\mathrm{mL}$ de extrato ( $\mu \mathrm{g}$ proteína $\mathrm{mL}^{-1}$ ).

\subsubsection{Atividades de quitinases}

As atividades de quitinases foram determinadas colorimetricamente, conforme descrito por Wirth \& Wolf (1990). O método baseia-se na liberação de fragmentos solúveis de quitina marcada com remazol violeta brilhante (CM-chitin RBV).

O conteúdo protéico de cada amostra foi ajustado para $5 \mu \mathrm{g}$ proteína $\mathrm{mL}^{-1}$ com citrato de sódio $0,1 \mathrm{M}(\mathrm{pH} 5,0)$. Para cada amostra, adicionaram-se $150 \mu \mathrm{L}$ do substrato CM-chitin RBV (LOWE Biochemica, Munique, Alemanha). Incubou-se por 
30 minutos em banho-maria à $37^{\circ} \mathrm{C}$. A reação foi interrompida com a adição de $150 \mu \mathrm{L}$ de $\mathrm{HCl} 1 \mathrm{~N}$. As amostras foram centrifugadas a $5000 \mathrm{~g} \mathrm{a} 4{ }^{\circ} \mathrm{C}$ por $5 \mathrm{~min}$. O sobrenadante foi utilizado para determinação da absorbância a $550 \mathrm{~nm}$. Como prova em branco foi utilizado o tampão de extração misturado ao substrato. Os resultados das atividades específicas foram expressos em unidades de absorbância a $550 \mathrm{~nm}$ por mg de proteína por minuto $\left(\mathrm{UA}_{550} \mathrm{mg}^{-1}\right.$ proteína $\min ^{-1}$ ). Foram utilizadas 4 repetições por amostra.

\subsubsection{Caracterização isoenzimática de quitinases em géis de poliacrilamida}

A caracterização isoenzimática de quitinases foi feita por eletroforese em géis de poliacrilamida $12 \%$, não-desnaturante, contendo $0,01 \%$ de quitina glicol (Trudel \& Asselin, 1989). A eletroforese foi realizada a $30 \mathrm{~mA}$ por gel constante, por 3 horas, utilizando-se tampão de corrida Tris-glicina (Tris-HCl - 123,8 mM; glicina 959,1 mM; pH 8,3). Foram utilizadas quantidades iguais de proteína total $(20 \mu \mathrm{g})$. A deteç̧ão das bandas com atividade de quitinases foi feita por coloração com Calcofluor branco M2R (Sigma), em Tris-HCl $500 \mathrm{mM}(\mathrm{pH}$ 8,9) e visualização sob luz UV (Trudel \& Asselin, 1989).

\subsubsection{Atividades de catalases}

As atividades de catalases foram determinadas segundo Aebi (1984), em $10 \mathrm{~mL}$ de tampão fosfato $100 \mathrm{mM}(\mathrm{pH} 7,5)$, contendo $25 \mu \mathrm{L}$ de $\mathrm{H}_{2} \mathrm{O}_{2}$ e $20 \mu \mathrm{g}$ de proteínas totais. A decomposição do $\mathrm{H}_{2} \mathrm{O}_{2}$ foi avaliada pela variação da absorbância a $240 \mathrm{~nm}$ durante $2 \mathrm{~min}$. $\mathrm{O}$ branco consistiu de extrato de proteína $(20 \mu \mathrm{g})$ e $1 \mathrm{~mL}$ de tampão fosfato. As atividades foram expressas em $-\Delta \mathrm{A}_{240} \mathrm{mg}^{-1}$ proteína $\mathrm{min}^{-1}$. 


\subsubsection{Caracterização isoenzimática de catalases em géis de poliacrilamida}

As proteínas com atividade de catalase foram identificadas por eletroforese em géis de poliacrilamida $12 \%$, não-desnaturante. Como tampão de corrida foi utilizado Tris-glicina (Tris- $\mathrm{HCl}-123,8 \mathrm{mM}$; glicina - 959,1 mM; $\mathrm{pH} \mathrm{8,3).} \mathrm{A}$ eletroforese foi realizada a $30 \mathrm{~mA}$ constante, por 6 horas, a $4^{\circ} \mathrm{C}$, utilizando-se $30 \mu \mathrm{g}$ de proteínas por amostra.

A deteç̧ão das atividades de catalase nos géis foi feita conforme descrito por Woodbury (1971), e baseia-se na redução do ferrocianeto de potássio III a ferrocianeto de potássio II. Primeiramente, o gel foi lavado com água destilada gelada, por $45 \mathrm{~min}$ (com troca a cada $15 \mathrm{~min}$, sob refrigeração) e imerso em $\mathrm{H}_{2} \mathrm{O}_{2} 0,005 \%(\mathrm{v} / \mathrm{v})$ por $10 \mathrm{~min}$. Em seguida, o gel foi tratado com uma solução contendo volumes iguais de $\mathrm{FeCl}_{3} .6 \mathrm{H}_{2} \mathrm{O} 1 \%(\mathrm{~m} / \mathrm{v})$ e $\mathrm{K}_{3} \mathrm{Fe}(\mathrm{CN})_{6} 1 \%(\mathrm{~m} / \mathrm{v})$, por $10 \mathrm{~min}$. As bandas com atividade de catalase (sem coloração) foram detectadas contra uma coloração de fundo azul escuro.

\subsubsection{Caracterização do perfil protéico em géis de poliacrilamida}

As proteínas $(5 \mu \mathrm{g})$ foram separadas em géis de poliacrilamida (12\%)SDS, utilizando Tris-glicina-SDS (Tris- $\mathrm{HCl}$ - 123,8 mM; glicina - 959,1 mM; SDS 17,3 mM; pH 8,3) como tampão. A eletroforese foi feita a $30 \mathrm{~mA}$ constante, por 2 horas. As proteínas foram visualizadas através de coloração com prata, utilizando-se o "Silver Staining Kit" (Pharmacia), conforme especificação do fabricante.

A análise dos perfis de proteínas das amostras foi feita por densitometria (Personal Densitometer, Molecular Dynamics), utilizando-se o programa FragmeNT Analysis (Molecular Dynamics). 


\subsection{Análise estatística}

Os dados foram submetidos à análise de variância e aplicação do teste F para todos os fatores e suas interações. Quando o resultado do teste $\mathrm{F}$ foi significativo, aplicou-se o teste de comparações múltiplas (teste $t$ de Student) a $p<0,05$ por meio do programa SAS (Statistical Analysis System) (SAS Institute, 1988). 


\section{RESULTADOS E DISCUSSÃO}

\subsection{Crescimento vegetal na presença de ácido salicílico}

\subsubsection{Parte aérea}

A produção de biomassa aérea (matéria seca da parte aérea - MSPA), independente da presença de AS e da inoculação com G. clarum, foi significativamente afetada pelo nível de $\mathrm{P}$ no substrato de cultivo (Figura 1). No início do desenvolvimento, 4 SAP, as plantas cultivadas sob condições de alto P apresentaram MSPA $40 \%$ menor do que sob condições de baixo $\mathrm{P}(\mathrm{p}<0,05)$. À medida que as plantas se desenvolveram, as que receberam a maior dose de $\mathrm{P}$ superaram as cultivadas sob baixa disponibilidade de P. Com $6 \mathrm{SAP}$, a produção de biomassa foi semelhante nas duas doses, ao passo que com 8 SAP, a MSPA das plantas cultivadas sob condições de alto $P$ foi $20 \%$ maior do que sob condições de baixo $\mathrm{P}(\mathrm{p}<0,05)$. $\mathrm{O}$ efeito depressivo do $\mathrm{P}$ no início do desenvolvimento das plantas sob condições de alto $\mathrm{P}$ pode ter ocorrido devido à indução de deficiência de algum outro nutriente, pela formação de complexos de baixa solubilidade com o fosfato, ou mesmo por inibição competitiva. Além disso, a maior concentração de $\mathrm{P}$ no substrato pode ter estimulado o desenvolvimento da microbiota. Sendo o P importante para os microrganismos, pois participa de processos de transferência de energia, como componente de moléculas de ATP e ADP (Tsai \& Rosseto, 1992), esta pode ter imobilizado momentaneamente os nutrientes essenciais para o crescimento vegetal.

O AS afetou a produção de biomassa aérea somente com 4 SAP (Figura 2), independente da concentração de $\mathrm{P}$ no substrato e do tratamento de 
inoculação. Nessa época de colheita, a aplicação de AS resultou em aumento de $70 \%$ na MSPA $(p<0,05)$. Não foram observadas diferenças significativas entre os tratamentos com e sem AS nas demais épocas de colheita. Ao contrário do que foi demonstrado neste experimento, Costa et al. (2000) observaram que plantas tratadas com AS apresentaram menor produção de biomassa aérea, possivelmente pelo fato de a dose utilizada pelos autores ter sido mais elevada. Esse efeito foi mais evidente na última época analisada, o que pode ter sido resultado de fitotoxicidade às plantas, visto que as aplicações do produto também foram feitas a cada dois dias.

A inoculação com $G$. clarum não causou alterações na MSPA com 4 SAP (Figura 3). Esse comportamento já era esperado, pois, nas fases iniciais do estabelecimento da simbiose, a planta não teve tempo hábil para se beneficiar da interação. Com $6 \mathrm{SAP}$ as plantas micorrizadas apresentaram biomassa aérea $13 \%$ menor do que as não-micorrizadas $(\mathrm{p}<0,05)$. Essa diminuição de crescimento do hospedeiro nas fases iniciais do estabelecimento da simbiose têm sido observada com relativa frequêencia e é atribuída ao dreno de carbono que o fungo impõe à planta para o seu estabelecimento e manutenção, numa fase em que a mesma ainda não se beneficiou da simbiose (Jakobsen, 1995; Bethlenfalvay et al., 1982). Na última época, com 8 SAP, as plantas micorrizadas produziram aproximadamente duas vezes mais MSPA do que as não-micorrizadas $(\mathrm{p}<0,05)$, o que indica efeito positivo da simbiose, resultado da provável melhoria do estado nutricional das plantas, além de outros benefícios propiciados pela simbiose (Siqueira \& Franco, 1988). Essa depressão de crescimento nas fases iniciais e posterior aumento de biomassa das plantas micorrizadas também foi observada por Nogueira \& Cardoso (2000) em soja.

Ao se desdobrar a interação significativa entre os fatores "Fungo" e "Nível de P", com 6 e 8 SAP, pode-se melhor observar os efeitos das doses de P sobre o crescimento das plantas micorrizadas e não-micorrizadas (Figura 4). Com $6 \mathrm{SAP}$, as plantas não-micorrizadas e cultivadas em condições de baixo $\mathrm{P}$ produziram aproximadamente $15 \%$ mais biomassa aérea do que as plantas não-micorrizadas e cultivadas em condições de alto $\mathrm{P}(\mathrm{p}<0,05)$. Por outro lado, na presença do fungo micorrízico, não houve efeito significativo das doses de $\mathrm{P}$ sobre a produção de biomassa 
das plantas, mas, nos dois níveis de $\mathrm{P}$, o crescimento foi menor que no controle nãomicorrizado sob baixo nível de P. Pelo desdobramento dessa interação, torna-se claro que na ausência de micorrização a maior dose de $\mathrm{P}$ foi desfavorável ao crescimento das plantas, possivelmente pelas razões expostas anteriormente, e que na presença do $G$. clarum houve redução de crescimento da planta nas duas condições de fornecimento de $\mathrm{P}$ em relação ao tratamento não-micorrizado sob baixo $\mathrm{P}$.

Já com 8 SAP, a MSPA de plantas não-micorrizadas, em condições de baixo e alto $P$, não diferiu estatisticamente $(p<0,05)$, enquanto que plantas micorrizadas em condições de alto $\mathrm{P}$ produziram mais biomassa $(30 \%)$ comparadas àquelas observadas em condições de baixa concentração de $\mathrm{P}(\mathrm{p}<0,05)$. Nota-se grande incremento no crescimento das plantas micorrizadas em relação a época anterior, principalmente no tratamento com alto P. Esse comportamento pode ser atribuído ao fato de que com o crescimento das plantas, o $\mathrm{P}$ disponível no substrato vai se exaurindo, tornando-se mais limitante no tratamento que recebeu a menor dose, daí o menor crescimento das plantas micorrizadas sob baixo $\mathrm{P}$ quando comparadas às plantas micorrizadas sob alto P. Esses dados demonstraram que, com 8 SAP, houve um efeito sinergístico entre a inoculação com G. clarum e a aplicação de alta concentração de P, resultando em maiores quantidades de biomassa aérea. É importante salientar que, mesmo em condições de baixa disponibilidade de $\mathrm{P}$, as plantas micorrizadas tiveram crescimento significativamente maior que as plantas não-micorrizadas, mesmo sob alta disponibilidade de $\mathrm{P}$, indicando $\mathrm{o}$ papel fundamental do fungo micorrízico no crescimento das plantas de feijoeiro nessas condições. 


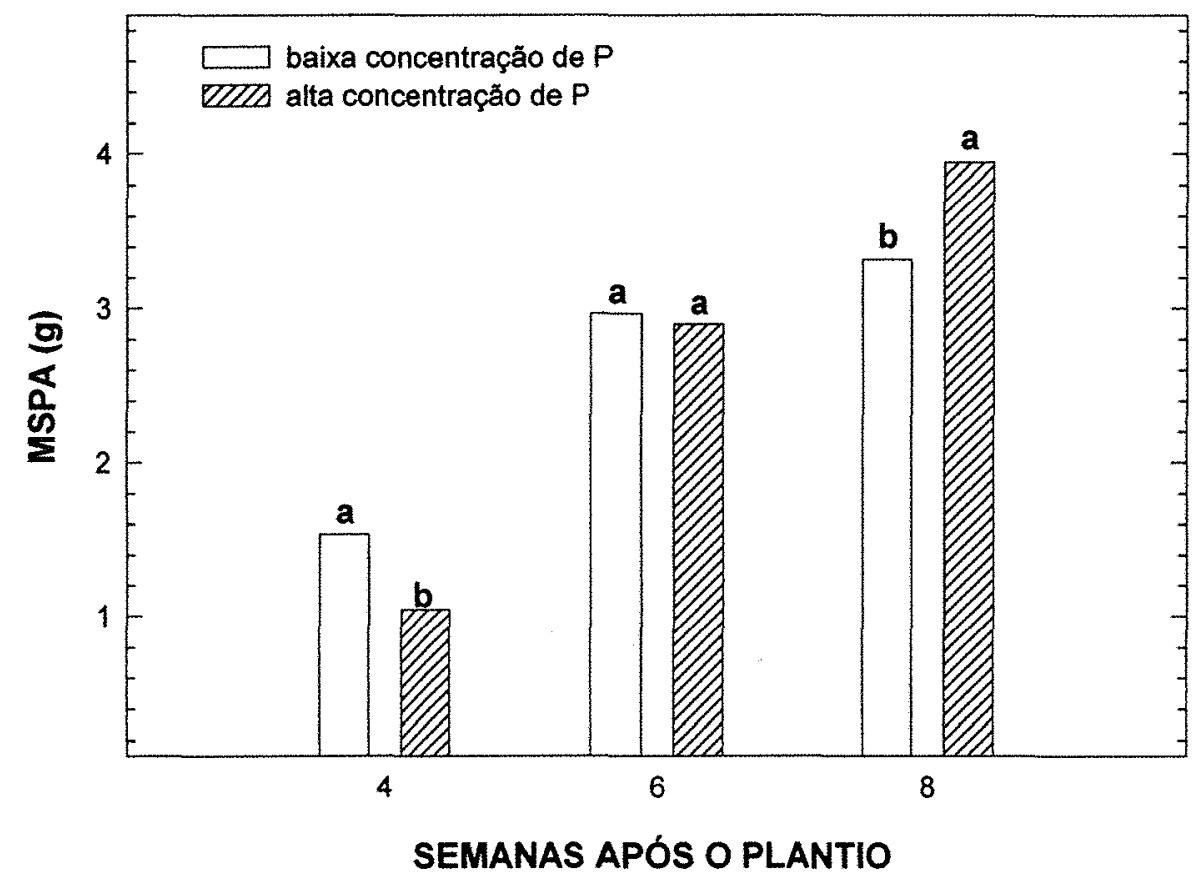

Figura 1. Produção de biomassa aérea (MSPA) por feijoeiros em condições de baixa ou alta concentração de $\mathrm{P}$ no substrato (20 ou $150 \mathrm{mg} \mathrm{P} \mathrm{kg}^{-1}$ de substrato). As colheitas foram realizadas 4,6 e 8 semanas após o plantio. As letras são usadas para comparar as médias entre os tratamentos em cada época de colheita. Médias seguidas da mesma letra não diferem estatisticamente (teste $t$, $\mathrm{p}<0,05)$. 


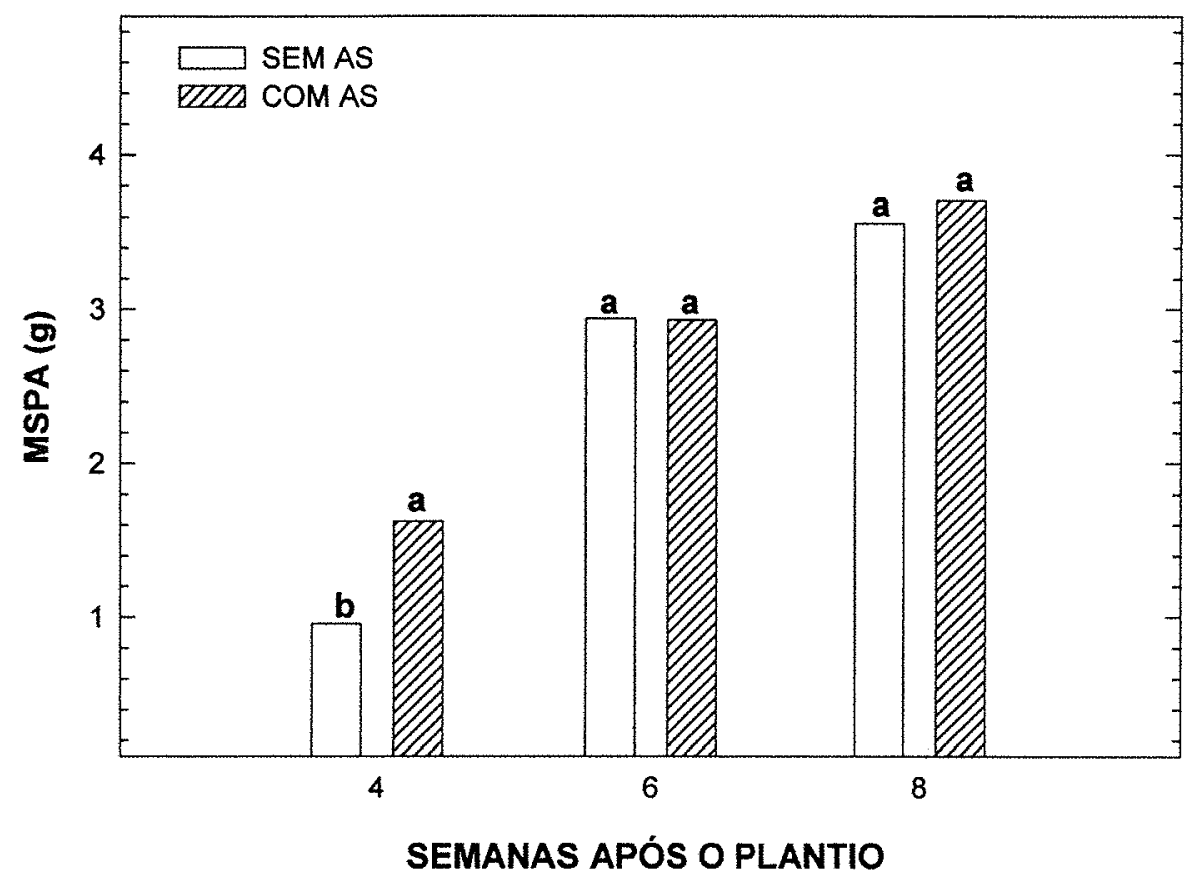

Figura 2. Produção de biomassa aérea (MSPA) por feijoeiros com ou sem aplicação de ácido salicílico (AS). As colheitas foram realizadas 4, 6 e 8 semanas após o plantio. As letras são usadas para comparar as médias entre os tratamentos em cada época de colheita. Médias seguidas da mesma letra não diferem estatisticamente (teste $t, \mathrm{p}<0,05$ ). 


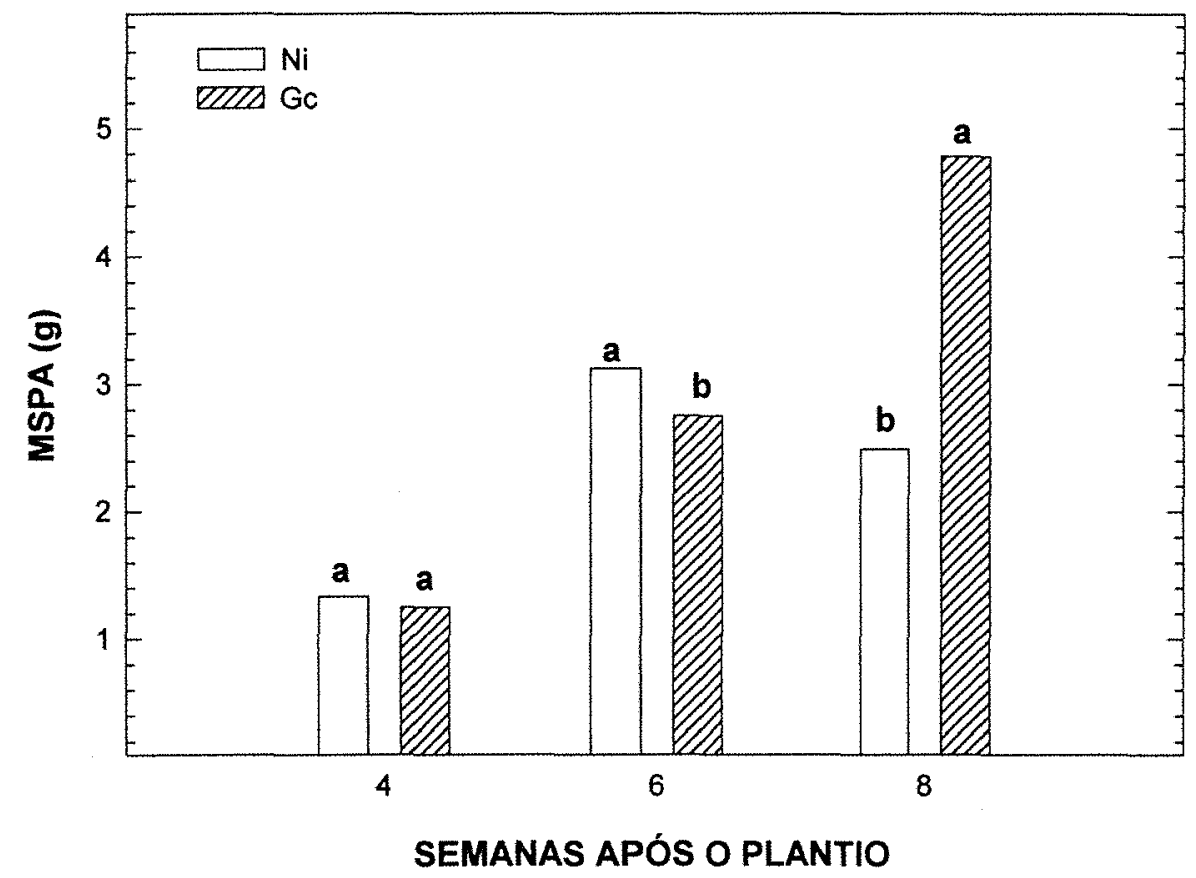

Figura 3. Produção de biomassa aérea (MSPA) por feijoeiros não-inoculados (Ni) ou inoculados com G. clarum $(\mathrm{Gc})$. As colheitas foram realizadas 4,6 e 8 semanas após o plantio. As letras são usadas para comparar as médias entre os tratamentos em cada época de colheita. Médias seguidas da mesma letra não diferem estatisticamente (teste $t, \mathrm{p}<0,05$ ). 


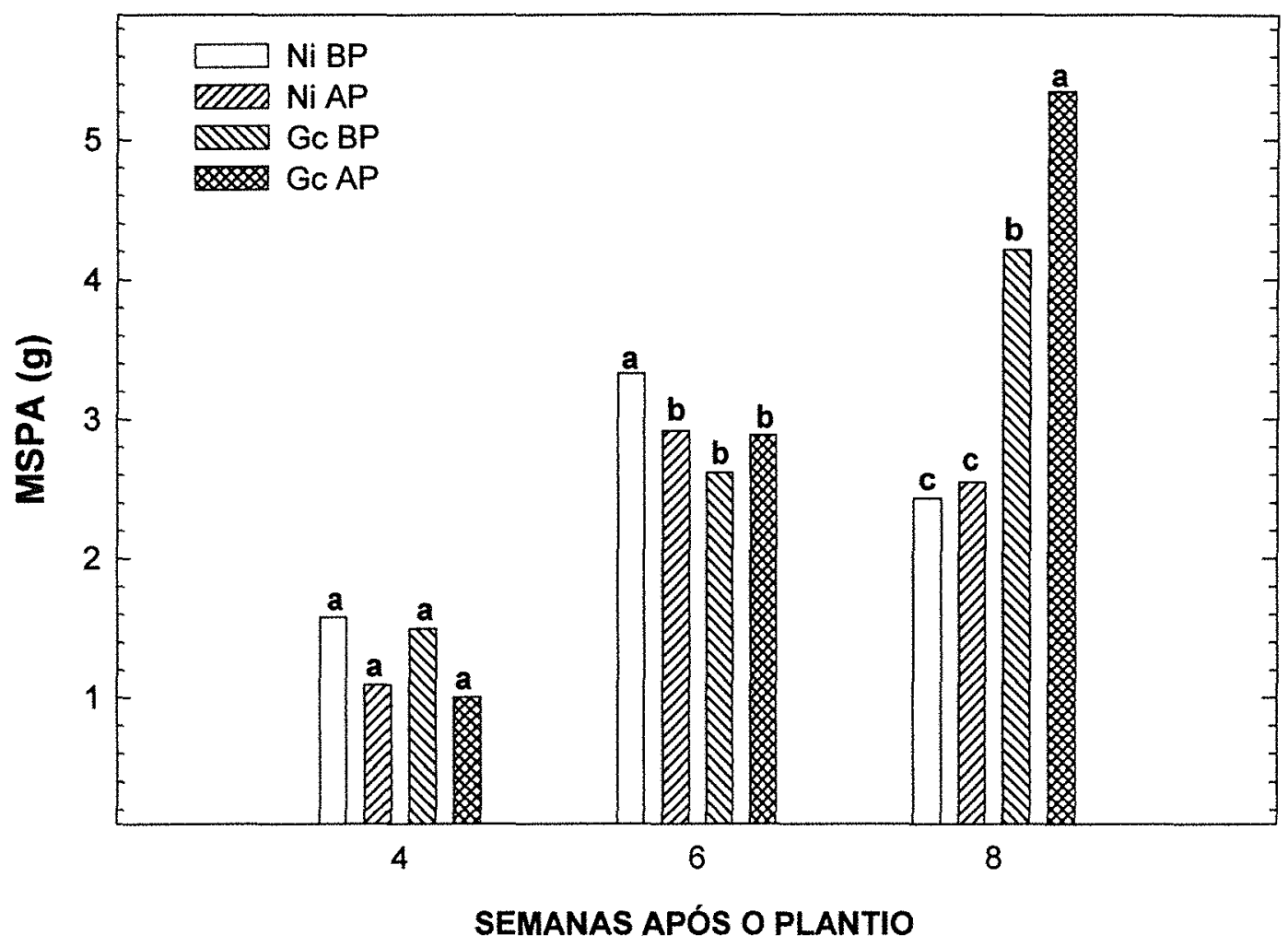

Figura 4. Produção de biomassa aérea (MSPA) por feijoeiros não-inoculados (Ni) ou inoculados com G. clarum $(\mathrm{Gc})$ em condições de baixa ou alta concentração de fósforo no substrato (BP, $20 \mathrm{ou} \mathrm{AP,} 150 \mathrm{mg} \mathrm{P} \mathrm{kg}^{-1}$ ). As colheitas foram realizadas 4, 6 e 8 semanas após o plantio. As letras são usadas para comparar as médias entre os tratamentos em cada época de colheita. Médias seguidas da mesma letra não diferem estatisticamente (teste $t, \mathrm{p}<0,05$ ). 


\subsubsection{Sistema radicular}

A produção de biomassa radicular (matéria seca do sistema radicular MSSR), independente da presença de AS e da inoculação com fungo micorrízico, foi significativamente afetada pelo nível de P no substrato de cultivo (Figura 5), de forma semelhante ao que ocorreu para a biomassa da parte aérea. Inicialmente, 4 SAP, a MSSR foi significativamente $30 \%$ maior nos tratamentos com baixa concentração de $\mathrm{P}$, em relação aos tratamentos com alta concentração de $\mathrm{P}(\mathrm{p}<0,05)$. Posteriormente, 6 e $8 \mathrm{SAP}$, as plantas cultivadas em condições de alta concentração de $\mathrm{P}$ produziram significativamente, $30 \%$ e $65 \%$ respectivamente, mais biomassa radicular do que as cultivadas em baixa concentração de $P(p<0,05)$. Esses dados mostram que o $P$ afetou de maneira diferente a produção de biomassa aérea e radicular $6 \mathrm{SAP}$, sendo que, nesse caso, a produção de biomassa radicular foi favorecida pela maior disponibilidade de $\mathrm{P}$ em relação à produção de biomassa aérea. Com $8 \mathrm{SAP}$, a resposta de produção de biomassa à adição de $\mathrm{P}$ foi maior para o sistema radicular (65\% de aumento), comparada com a resposta de crescimento da parte aérea ( $30 \%$ de aumento).

A inoculação com $G$. clarum não causou alterações significativas na MSSR 4 SAP (Figura 6). Já, 6 SAP, as plantas inoculadas apresentaram uma biomassa radicular aproximadamente $25 \%$ menor do que as não-micorrizadas $(p<0,05)$. Com o desenvolvimento das plantas, $8 \mathrm{SAP}$, aquelas inoculadas com G. clarum produziram aproximadamente $60 \%$ mais biomassa radicular do que as não-micorrizadas $(\mathrm{p}<0,05)$. Esses dados são semelhantes aos observados por Costa et al.(2000), e sugerem que a inoculação com fungos micorrízicos pode induzir uma depressão transiente da produção de biomassa radicular, que, nesse caso, ocorreu de forma semelhante para a parte aérea. É de se esperar que, os mecanismos pelos quais isso ocorreu, atua de forma semelhante nas duas partes avaliadas da planta.

Interações significativas entre os fatores "fungo" e "nível de P" foram observadas nas épocas de avaliação 6 e 8 SAP (Figura 7). Com 4 SAP, as plantas nãomicorrizadas sob baixo $\mathrm{P}$ apresentaram tendência de maior biomassa em relação às plantas sob alto $P$, embora as diferenças não tenham sido estatisticamente distintas. Com 
$6 \mathrm{SAP}$, na ausência de micorrização, o comportamento foi invertido. As plantas nãomicorrizadas e cultivadas em condições de alta concentração de $\mathrm{P}$ produziram aproximadamente $50 \%$ mais biomassa radicular do que as plantas não-micorrizadas, cultivadas em condições de baixa concentração de $\mathrm{P}(\mathrm{p}<0,05)$. Já a produção de MSSR por plantas inoculadas com $G$. clarum não foi afetada significativamente pela concentração de $P$, resultando em valores estatisticamente iguais ao do tratamento nãomicorrizado sob baixo $\mathrm{P}$. Ao contrário, com $8 \mathrm{SAP}$, as plantas micorrizadas e em condições de alto $\mathrm{P}$ produziram aproximadamente $90 \%$ mais biomassa radicular do que plantas micorrizadas sob condições de baixo P. Considerando-se as condições de alta disponibilidade de $\mathrm{P}$, a micorrização também resultou em aumento da produção da biomassa radicular em cerca de $90 \%(\mathrm{p}<0,05)$, destacando o importante envolvimento do fungo micorrízico em favorecer a planta na sua produção de biomassa quando a simbiose está totalmente estabelecida. Esses dados sugerem que a depressão transiente de produção de MSSR observada com $6 \mathrm{SAP}$, ocorre sob condições de alto $\mathrm{P}$, e é relativa, já que diferenças significativas na MSSR das plantas inoculadas e sob condições de baixo e alto $P$ não foram observadas nessa época de colheita.

Interação significativa entre os fatores "fungo" e "AS" foi observada apenas com 6 SAP $(\mathrm{p}<0,05)$ (Figura 8). Nesse caso, a presença do AS estimulou a produção de biomassa radicular apenas nos tratamentos não-micorrizados, enquanto nos micorrizados não houve efeito do AS. Embora existam vários estudos sobre o papel do AS nos mecanismos de defesa da planta, que também pode estar envolvido no mecanismo de controle da colonização micorrízica, pouco se sabe sobre seu efeito direto no crescimento das plantas e de que forma esse efeito pode ser alterado na condição de micorrização. 


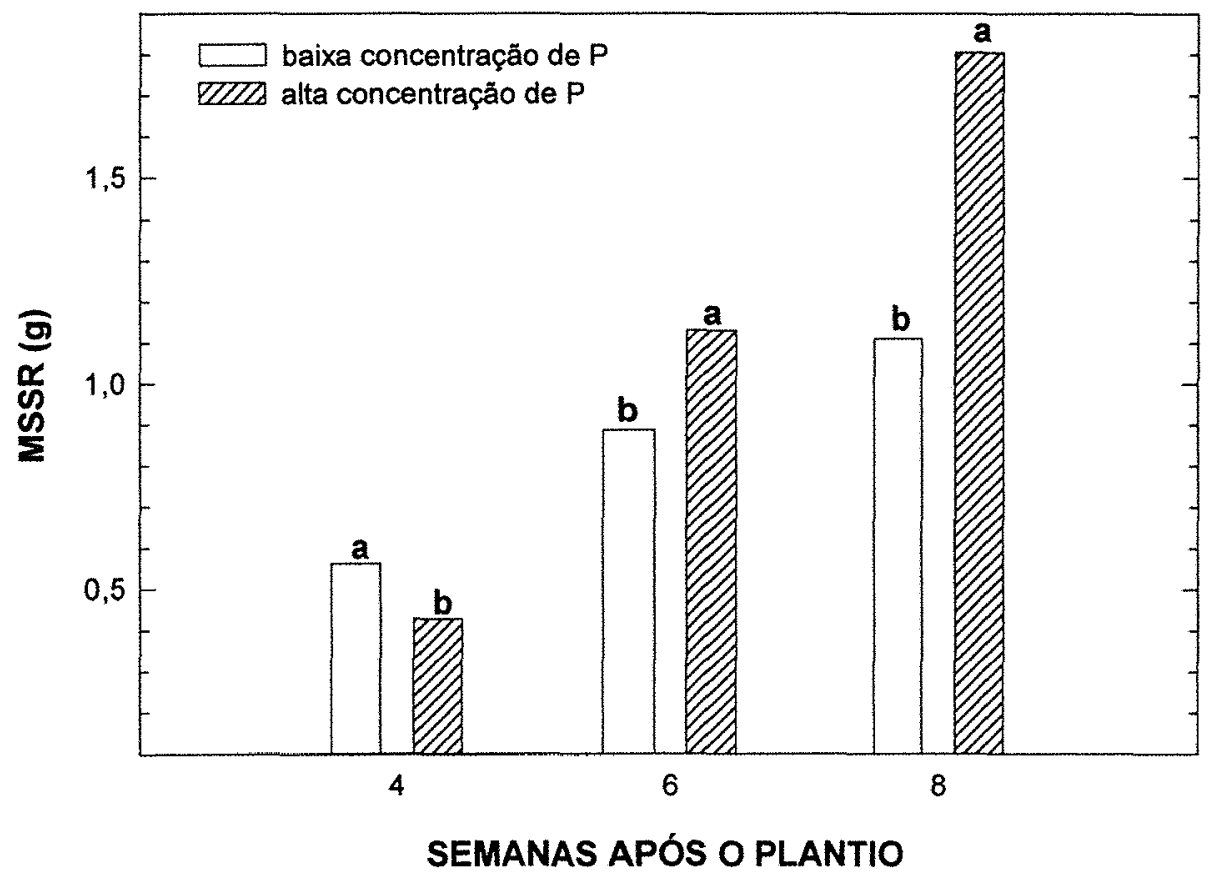

Figura 5. Produção de matéria seca do sistema radicular (MSSR) por feijoeiros em condições de baixa ou alta concentração de fósforo no substrato ( 20 ou 150 $\mathrm{mg} \mathrm{P} \mathrm{kg}{ }^{-1}$ de substrato). As colheitas foram realizadas 4, 6 e 8 semanas após o plantio. As letras são usadas para comparar as médias entre os tratamentos, em cada época de colheita. Médias seguidas da mesma letra não diferem estatisticamente (teste $t, \mathrm{p}<0,05$ ). 


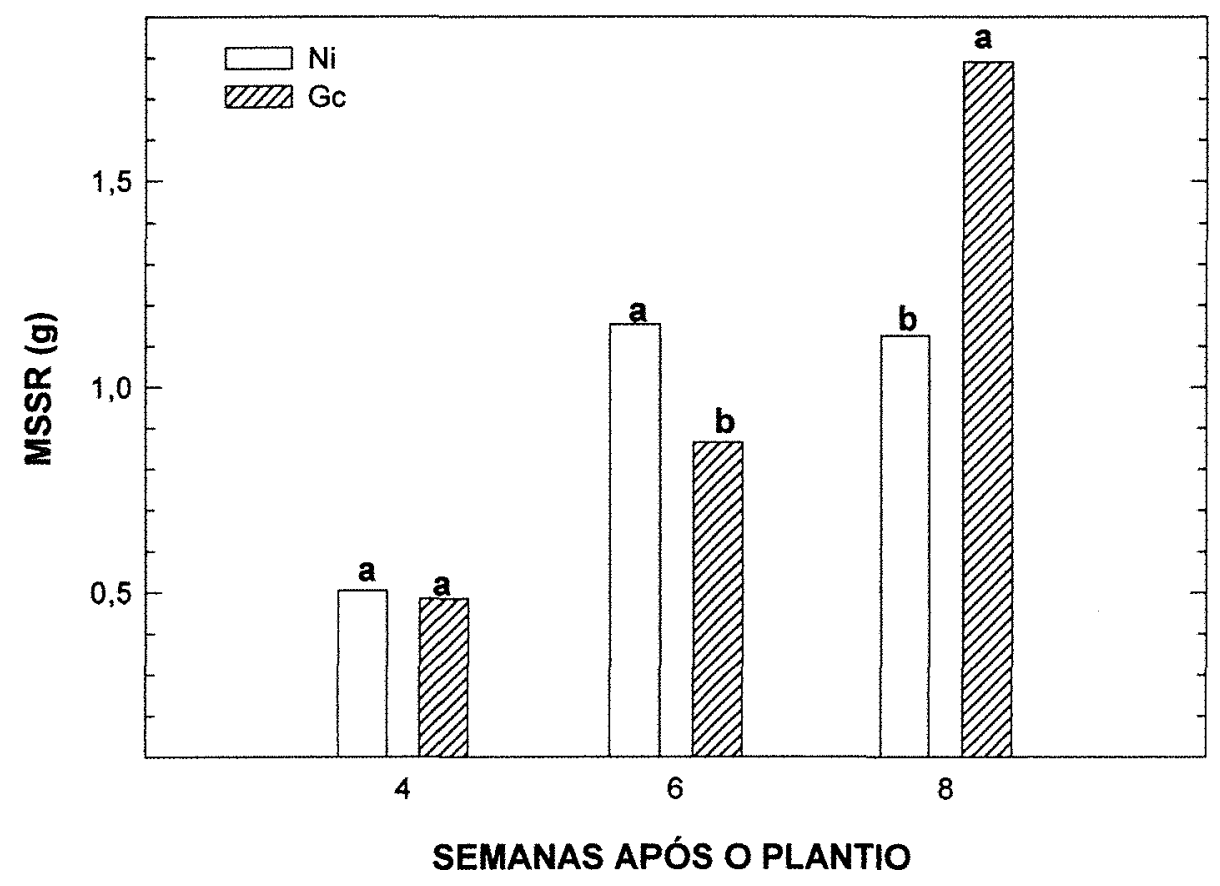

Figura 6. Produção de matéria seca do sistema radicular (MSSR) por feijoeiros nãoinoculados ou inoculados com G. clarum. As colheitas foram realizadas 4, $6 \mathrm{e}$ 8 semanas após o plantio. As letras são usadas para comparar as médias entre os tratamentos em cada época de colheita. Médias seguidas da mesma letra não diferem estatisticamente (teste $t, \mathrm{p}<0,05$ ). 


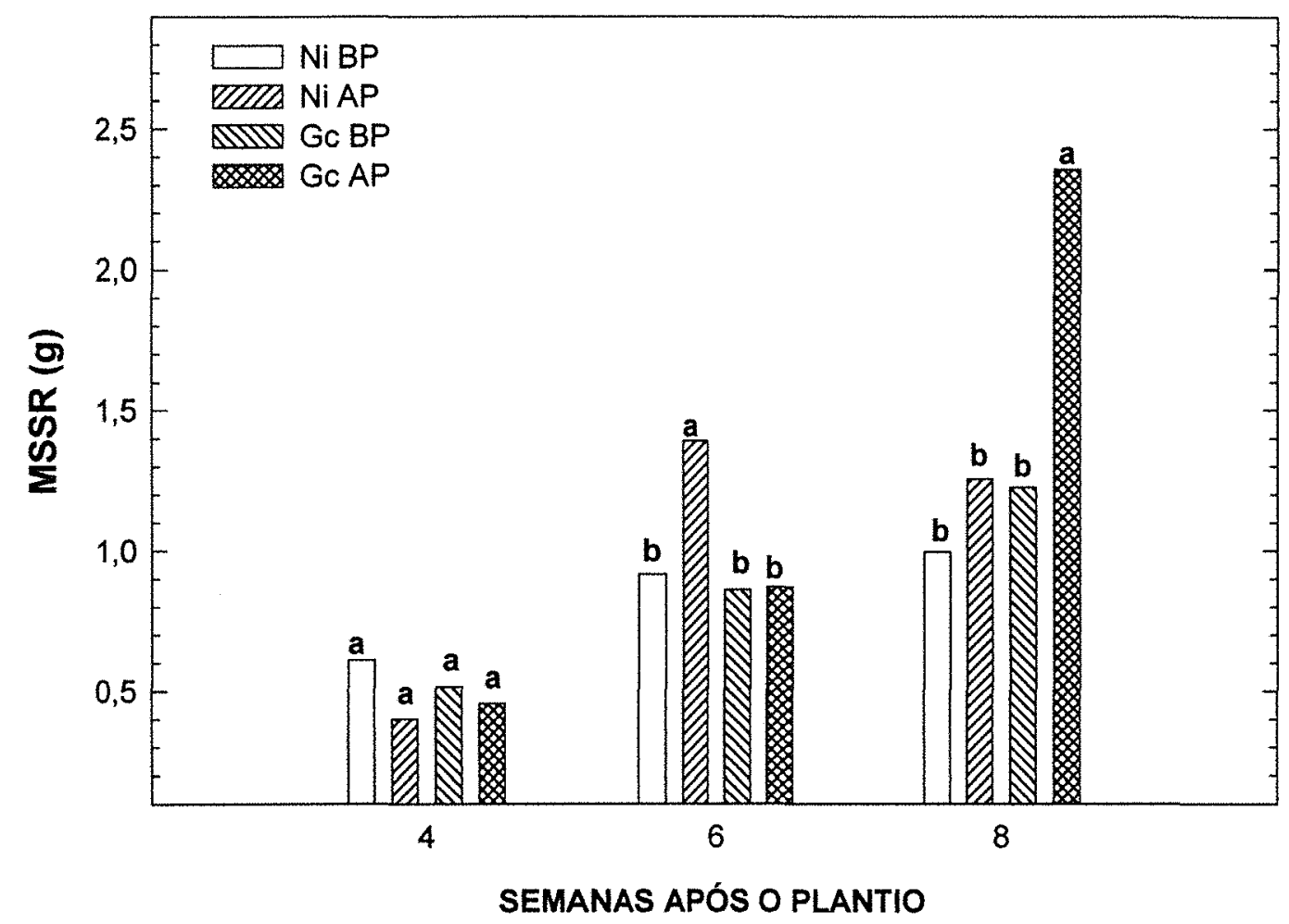

Figura 7. Produção de matéria seca do sistema radicular (MSSR) por feijoeiros nãoinoculados ou inoculados com $G$. clarum em condições de baixa ou alta concentração de $\mathrm{P}$ no substrato (BP, $20 \mathrm{ou} \mathrm{AP,} 150 \mathrm{mg} \mathrm{P} \mathrm{kg}^{-1}$ de substrato). As colheitas foram realizadas 4,6 e 8 semanas após plantio. As letras são usadas para comparar as médias entre os tratamentos, em cada época de colheita. Médias seguidas da mesma letra não diferem estatisticamente (teste $t$, $\mathrm{p}<0,05)$. 


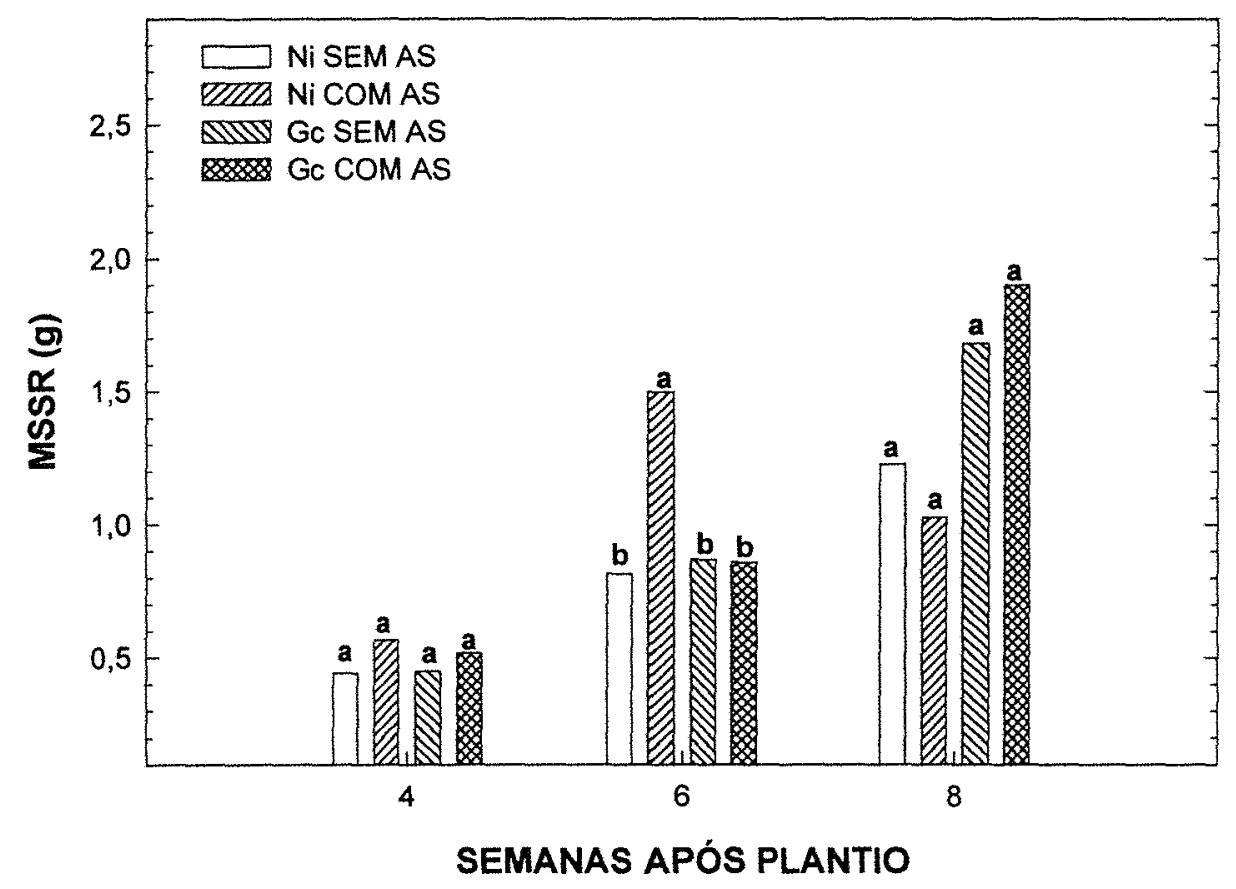

Figura 8. Produção de matéria seca do sistema radicular (MSSR) por feijoeiros nãoinoculados ou inoculados com $G$. clarum e aplicação ou não de AS. As colheitas foram realizadas 4,6 e 8 semanas após plantio. As letras são usadas para comparar as médias entre os tratamentos, em cada época de colheita. Médias seguidas da mesma letra não diferem estatisticamente (teste $t, \mathrm{p}<0,05$ ). 


\subsection{Crescimento vegetal na presença de formononetina}

\subsubsection{Parte aérea}

A MSPA, independente da presença de FOR e inoculação com $G$. clarum, não foi significativamente afetada pelo nível de $\mathrm{P}$ no substrato de cultivo 4 e 6 SAP $(p<0,05)$ (Figura 9). Apenas com 8 SAP, as plantas cultivadas com alto $P$ produziram $20 \%$ mais biomassa aérea do que plantas cultivadas com baixo P. Nesse caso, não houve efeito negativo significativo da maior dose de $\mathrm{P}$ nas fases iniciais de desenvolvimento da planta, como ocorreu na presença do $\mathrm{AS}$, sendo que as plantas que receberam mais $\mathrm{P}$ também apresentaram produção de biomassa significativamente maior na última época de colheita.

A inoculação com $G$. clarum não causou alterações significativas na MSPA, 4 e 6 SAP (Figura 10). No entanto, 8 SAP, as plantas inoculadas apresentaram uma biomassa aérea 2 vezes maior do que as plantas não-micorrizadas $(\mathrm{p}<0,05)$. Assim como foi observado para os tratamentos com AS, as plantas micorrizadas e nãomicorrizadas também não diferiram entre si no início do estabelecimento da simbiose. Posteriormente, com a evolução do processo, embora sem efeito significativo, as plantas micorrizadas apresentaram uma tendência de diminuição de sua biomassa, possivelmente também decorrente do dreno de carbono causado pelo estabelecimento $\mathrm{e}$ manutenção do fungo micorrízico (Jakobsen, 1995; Bethlenfalvay et al., 1992). Finalmente, na última coleta, as plantas micorrizadas apresentaram expressivo aumento de crescimento.

A aplicação de FOR não afetou significativamente a produção de MSPA, nas diferentes épocas de colheita $(p<0,05)$. Da mesma forma, interações significativas entre os diferentes fatores não foram observadas nas diferentes épocas de colheita $(p<0,05)$. Silva Júnior \& Siqueira (1998) também não observaram aumentos no crescimento, nodulação e nutrição de plantas de soja associadas a diferentes espécies de fungos micorrízicos e tratadas com FOR. Romero et al. (1998) observaram que em soja, 
a produção da MSPA também não foi influenciada pela aplicação de FOR na presença de fungo micorrízico, mas que no tratamento sem FMA esse composto estimulou o crescimento da soja. Os autores não encontraram uma explicação plausível para o ocorrido. O mesmo fenômeno foi observado por Fries et al. (1998) em plantas de milho. Um fator importante a ser considerado é que esses experimentos foram conduzidos em vasos, o que pode determinar resultados diferentes daquelas obtidas em condições de campo, como os efeitos positivos decorrentes da aplicação de FOR em milho observados por Siqueira et al. (1992).

Apesar das potencialidades do uso desse composto fenólico visando estímulo à micorrização e conseqüente aumento do crescimento das plantas, pelo benefício da simbiose micorrízica, seu mecanismo de ação ainda parece controverso, havendo necessidade de futuras pesquisas visando sua elucidação. 


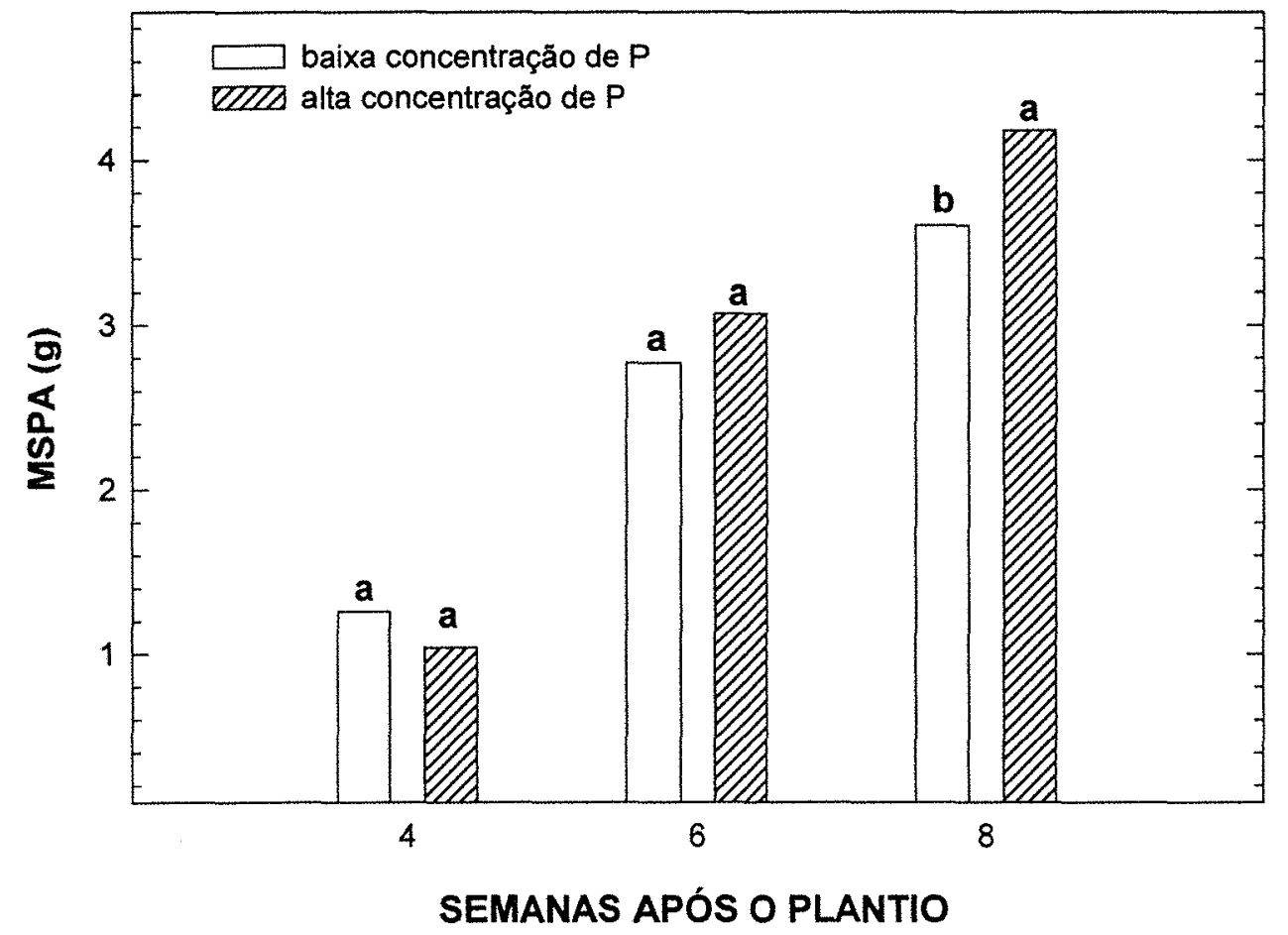

Figura 9. Produção de biomassa aérea (MSPA) por feijoeiros em condições de baixa e alta concentração de $\mathrm{P}$ no substrato (20 ou $150 \mathrm{mg} \mathrm{P} \mathrm{kg}^{-1}$ de substrato). As colheitas foram realizadas 4,6 e 8 semanas após o plantio. As letras são usadas para comparar as médias entre os tratamentos, em cada época de colheita. Médias seguidas da mesma letra não diferem estatisticamente (teste $t$, $\mathrm{p}<0,05)$. 


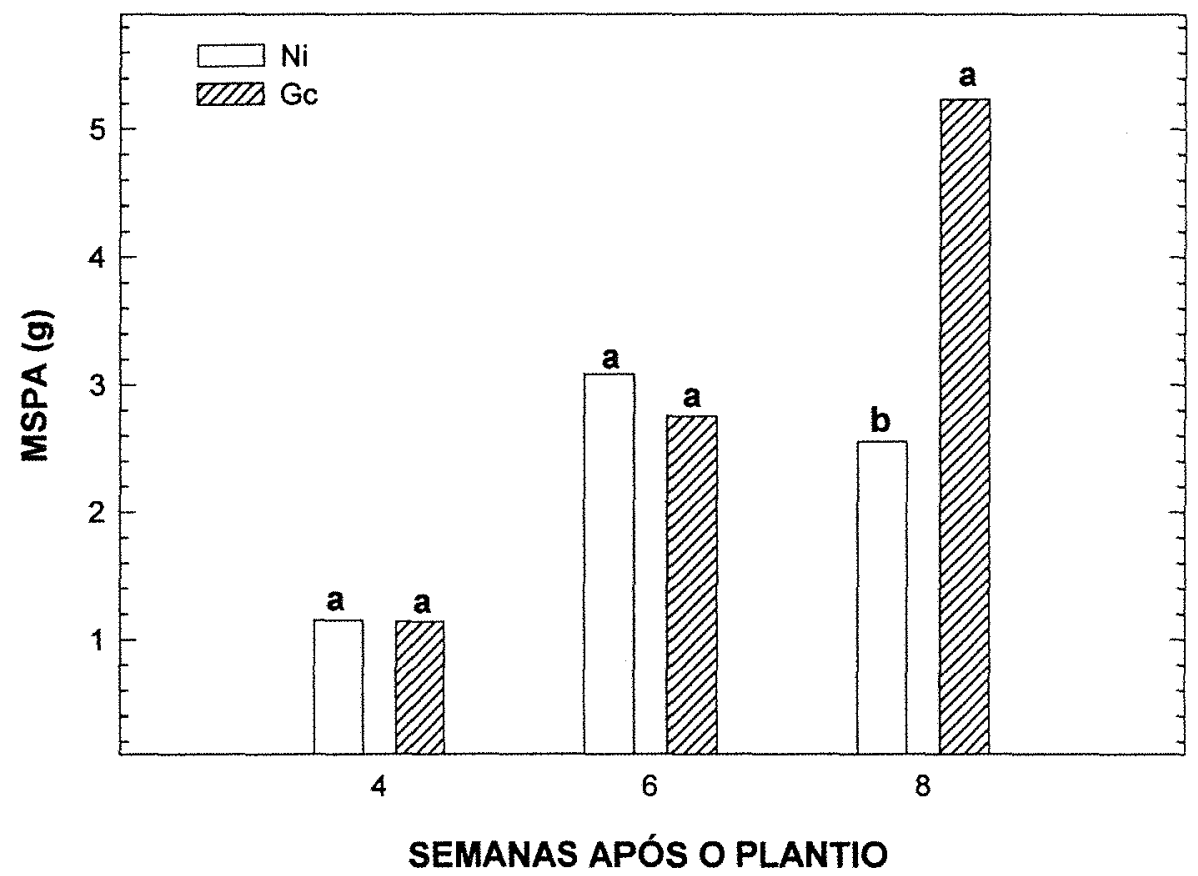

Figura 10. Produção de biomassa aérea (MSPA) por feijoeiros não-inoculados ou inoculados com G. clarum. As colheitas foram realizadas 4, 6 e 8 semanas após o plantio. As letras são usadas para comparar as médias entre os tratamentos, em cada época de colheita. Médias seguidas da mesma letra não diferem estatisticamente (teste $t, \mathrm{p}<0,05$ ). 


\subsubsection{Sistema radicular}

A produção de MSSR, não foi significativamente afetada pela concentração de $\mathrm{P}$ no substrato de cultivo, pela presença do fungo micorrízico ou aplicação de FOR, com e 4 e 6 SAP. Com 8 SAP, houve efeito significativo da interação entre os fatores "P", "fungo" e "FOR" ( $<0,05)$ (Figura 11). Os resultados demonstraram que não houve efeito significativo da micorrização sobre a MSSR nas condições de baixo nível de $\mathrm{P}$ na ausência de FOR, $(\mathrm{p}<0,05)$. Porém, a produção da MSSR foi 1,7 vezes maior no tratamento inoculado com $G$. clarum em condições de alto $\mathrm{P}$ e na ausência de FOR. Na presença de FOR, os tratamentos inoculados com G. clarum em condições de baixo $\mathrm{P}$, apresentaram produção da MSSR $45 \%$ maior que o tratamento não-inoculado, ao passo que, nas condições de alto $P$, não houve efeito da micorrização sobre essa variável. É importante notar que a FOR causou inversão das respostas da planta quanto à micorrização, sob os dois regimes de fornecimento de P. Nesse caso, a FOR estimulou a produção de biomassa de raizes nas plantas micorrizadas sob regime de baixo $P$, enquanto que no regime de alto $P$ houve inibição do efeito da micorrização. Romero et al. (1998) observaram que a produção da MSSR de soja foi aumentada pela FOR apenas nas plantas não-micorrizadas.

Fries et al. (1998) verificaram em seu trabalho que a MSSR da soja foi pouco influenciada pela presença de FOR em tratamentos com e sem micorrização. Apenas no tratamento com a segunda maior dose de $\mathrm{P}$, o fornecimento de FOR na ausência de micorrização resultou em maior biomassa radicular comparada ao tratamento micorrizado, que não recebeu FOR. Os autores atribuíram esse comportamento ao estímulo da FOR ao crescimento das raízes não-micorrizadas e uma diminuição de crescimento das raízes micorrizadas resultante do dreno de carbono imposto pelo FMA sob condições de alta disponibilidade de $P$. 


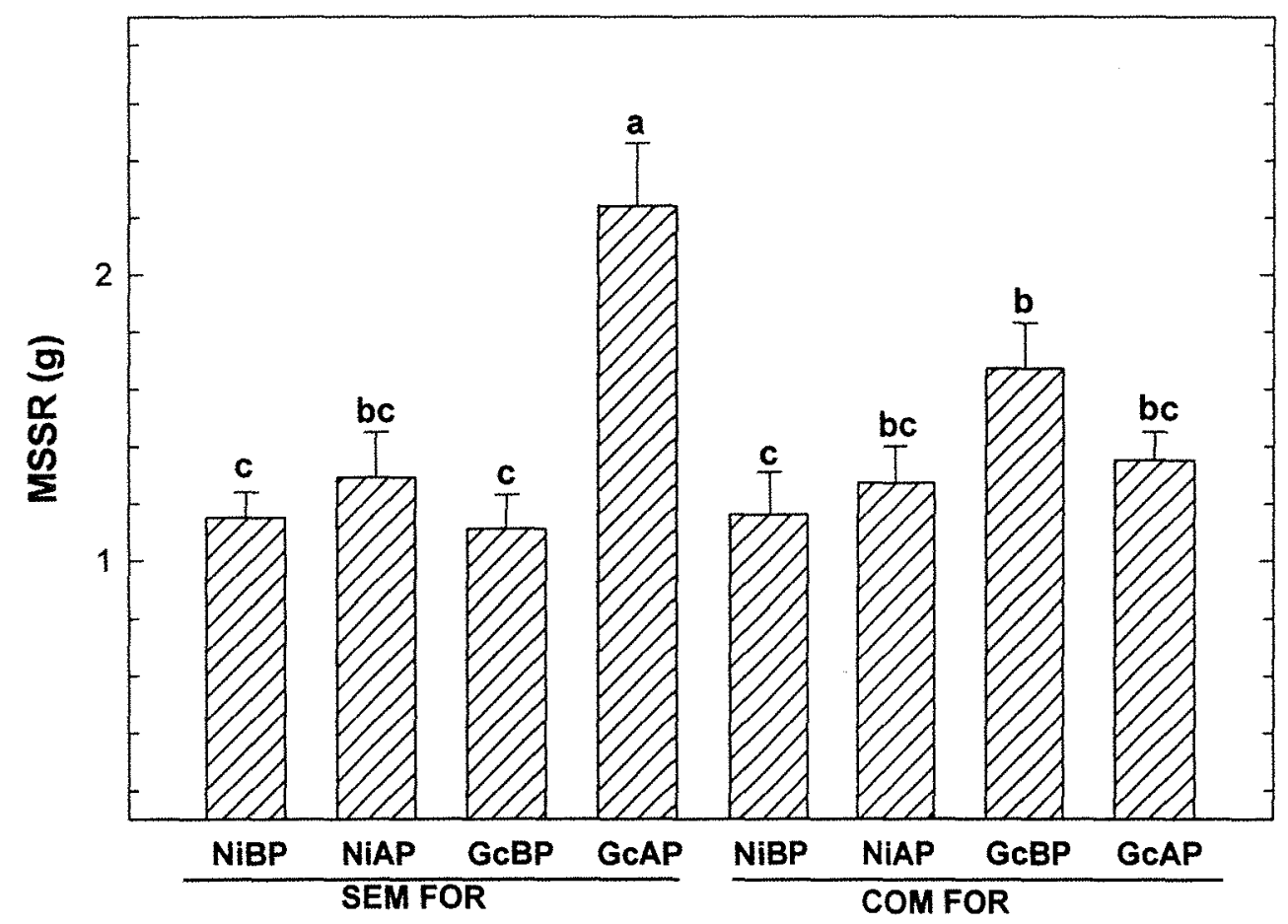

Figura 11. Produção de matéria seca do sistema radicular (MSSR) por feijoeiros nãoinoculados (Ni) ou inoculados com G. clarum $(\mathrm{Gc})$ em condições de baixo $\mathrm{P}$ (BP, $20 \mathrm{mg} \mathrm{P} \mathrm{kg}^{-1}$ ) e alto $\mathrm{P}$ (AP, $150 \mathrm{mg} \mathrm{P} \mathrm{kg}^{-1}$ ) 8 semanas após plantio. As letras são usadas para comparar as médias entre os tratamentos. Médias seguidas da mesma letra não diferem estatisticamente (teste $t ; \mathrm{p}<0,05$ ). 


\subsection{Colonização intrarradicular}

\subsubsection{Efeito do ácido salicílico na colonização intrarradicular.}

A colonização intrarradicular, independentemente da presença de AS, foi significativamente afetada pelo nível de $\mathrm{P}$ no substrato de cultivo $(\mathrm{p}<0,05)$ (Figura 12A), sendo menor nos tratamentos com alto $P$, em relação aos tratamentos com baixo $P$. Nota-se que a evolução da colonização intrarradicular foi mais rápida nas condições de baixo $\mathrm{P}$, havendo grande evolução de $4 \mathrm{SAP}$ para $6 \mathrm{SAP}$, enquanto que nas condições de alto $P$ essa variável somente apresentou um incremento mais tardiamente, de 6 SAP para 8 SAP. Essa diferença na taxa de ocupação interna das raízes pode ser atribuída ao fato de que, à medida que a planta se desenvolve, o P é consumido do substrato, tendo sua concentração diminuída, o que pode tornar as condições para a evolução da colonização micorrízica mais favoráveis. $\mathrm{O}$ efeito inibitório do $\mathrm{P}$ sobre a colonização das raízes por FMAs é conhecido de longa data (Abbott et al., 1984). No entanto, o mecanismo bioquímico que determina o menor crescimento fúngico intrarradicular é desconhecido (Koide \& Li, 1990). Tem sido sugerido que o sistema de defesa vegetal pode ser ativado em condições de alto $\mathrm{P}$ e estaria envolvido no controle do desenvolvimento de MAs (Lambais \& Mehdy, 1995).

A colonização radicular foi significativamente afetada pelo AS apenas com $6 \mathrm{SAP}$, sendo que na média das duas doses de $\mathrm{P}$, a colonização das plantas que receberam AS foi mais de duas vezes superior às não tratadas com AS. Ao contrário do que se esperava, a aplicação de AS não inibiu a colonização intrarradicular por $G$. clarum. Costa et al. (2000) observaram que a aplicação de $150 \mu \mathrm{mol}$ de AS às raízes de feijoeiro inibiu a colonização intrarradicular por $G$. clarum. A não inibição da colonização intrarradicular neste experimento pode ter sido resultado da menor concentração de AS utilizada, comparada com a dose utilizada por Costa et al. (2000). Desses resultados contrastantes, pode-se inferir que são vários os fatores que podem 
estar relacionados com as respostas de colonização radicular na presença e ausência de AS. É possivel que, não apenas as diferentes doses de AS, mas também as condições em que os experimentos foram conduzidos, tenham contribuído para essa resposta diferenciada.

\subsubsection{Efeito da Formononetina na colonização intrarradicular.}

A colonização intrarradicular, independentemente da presença da FOR, foi significativamente afetada pelo nível de P no substrato de cultivo, sendo menor nos tratamentos com alto P $(\mathrm{p}<0,05)$ (Figura 12B). Nogueira \& Cardoso (2000) observaram que, nos tratamentos com baixa concentração de $\mathrm{P}$, o nível de colonização radicular aumentou com a idade da planta, ao passo que nas maiores doses de $\mathrm{P}$, os niveis de colonização permaneceram baixos. Tendências de supressão da colonização intrarradicular com o aumento das doses de $\mathrm{P}$, sugerindo inibição do processo, também foram verificadas por Lambais \& Cardoso (1988), Antunes \& Cardoso (1991), ColozziFilho \& Siqueira (1986).

Não foi observado efeito significativo da aplicação de FOR sobre a colonização intrarradicular (figura 12B). Apenas na última época, embora a interação entre P e FOR não tenha sido significativa ao nível considerado (Apêndice 2), houve uma tendência de, o tratamento com FOR, causar um estímulo à colonização no tratamento com alto $P$. Neste caso, a colonização intrarradicular foi $50 \%$ maior no tratamento com FOR do que no tratamento sem FOR. Os resultados sugerem que a FOR estimulou a colonização intrarradicular somente em condições de alto $\mathrm{P}$ e tardiamente. Essa tendência de aumento da colonização interna na última época, na condição de alto $\mathrm{P}$, pode ter contribuído para que não houvesse aumento da biomassa do sistema radicular das plantas (Figura 11), decorrente da possível competição por carboidratos entre os simbiontes.

Fries et al. (1998) observaram que em plantas de milho, 3 semanas após a inoculação com fungos micorrízicos, em condições de baixo $\mathrm{P}$, a colonização 
intrarradicular foi maior nos tratamentos com FOR. Em condições de alto P, a colonização se manteve semelhante aos tratamentos sem o composto fenólico. É possível esperar um resultado semelhante para o feijoeiro pois, com o envelhecimento das plantas, pôde-se verificar tendências semelhantes aos resultados encontrados pelos autores.

Silva Júnior \& Siqueira (1998) utilizando diferentes espécies de FMAs, verificaram que a FOR estimulou a colonização intrarradicular de soja com todas as espécies, dentre as quais G. clarum. Esses resultados foram verificados aos 30 e 50 dias após a inoculação.

Tem-se observado que compostos fenólicos são capazes de estimular diferencialmente a germinação de esporos, o crescimento do tubo germinativo e a colonização das raízes. Porém, Bécard et al. (1995) demonstraram, através do uso de mutantes vegetais deficientes desses compostos, que a colonização das raízes de milho por espécies de FMAs não foi afetada pela ausência de flavonóides. Entretanto, Tsai \& Phillips (1991) observaram que, em raízes de alfafa, a exsudação de formononetina, estimulou significativamente a germinação de espécies de Glomus.

Há necessidade de estudos mais detalhados do processo de sinalização entre os simbiontes por meio dos compostos fenólicos. É possível que ocorra modulação da expressão não somente de um composto, mas de uma combinação de diferentes compostos exsudados de raízes, durante o desenvolvimento de MAs, os quais poderão regular o estabelecimento a simbiose. 


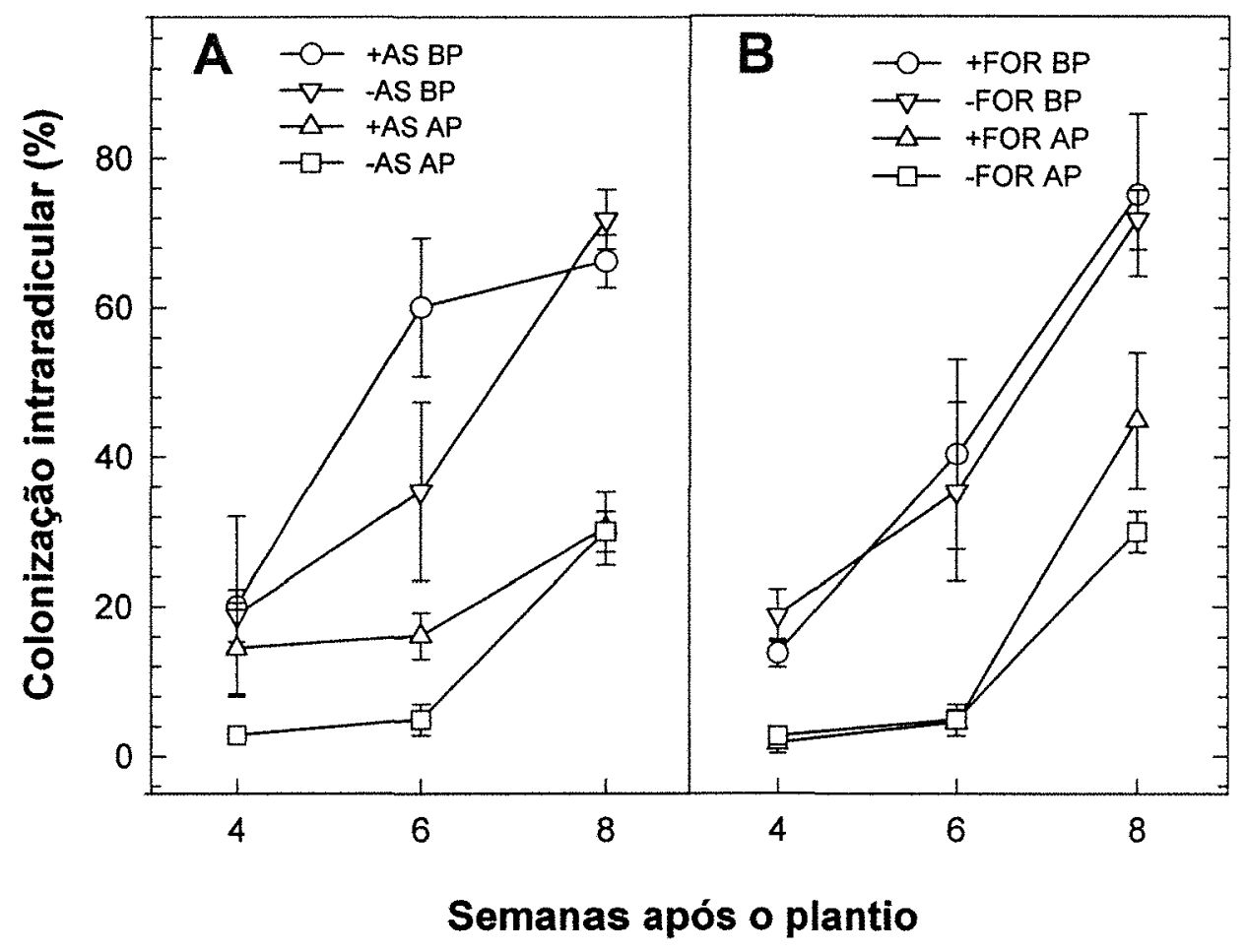

Figura 12. Porcentagem de colonização de raízes de feijoeiro por Glomus clarum, em condições de baixa (BP) e alta concentração de P (AP). A. Com aplicação de ácido salicílico (AS). B. Com aplicação da formononetina (FOR). BP: $20 \mathrm{mg}$ $\mathrm{P} \mathrm{kg}^{-1}$ de substrato; AP: $150 \mathrm{mg} \mathrm{P} \mathrm{kg}^{-1}$ de substrato. 


\subsection{Atividades e padrão isoenzimático de quitinases}

\subsubsection{Efeito do ácido salicílico nas atividades de quitinases}

No inicio do desenvolvimento das MAs, 4 e $6 \mathrm{SAP}$, as atividades específicas de quitinases em raízes colonizadas por G. clarum foram significativamente maiores em relação às não-micorrizadas, sendo $16 \%$ e $10 \%$, respectivamente, independente do nível de $\mathrm{P}$ no substrato de cultivo e da aplicação de $\mathrm{AS}(\mathrm{p}<0,05)$ (Figura 13). A aplicação de AS induziu $7 \%$ as atividades de quitinases, em relação ao controle sem AS apenas com 4 SAP $(\mathrm{p}<0,05)$ (Figura 14), independentemente da colonização micorrízica e dos níveis de $P$. Efeito significativo $(p<0,05)$ da interação entre os fatores "fungo" e "fósforo" foi observado apenas com 8 SAP (Figura 15). Nessa época, a atividade de quitinases nas plantas micorrizadas foi significativamente maior nas condições de alto $\mathrm{P}$, em relação às condições de baixo $\mathrm{P}(\mathrm{p}<0,05)$ (Figura 15). Essa maior atividade de quitinases nas condições de alto $\mathrm{P}$, nas raízes das plantas micorrizadas, pode auxiliar a explicar a menor taxa de colonização radicular nas condições de alto P (Figura 12A), tendo em vista que as quitinases são inibidoras do crescimento fúngico por apresentarem atividade hidrolítica sobre um dos principais constituintes de sua parede celular, a quitina. De modo contrário, também têm-se observado que o aumento da atividade de quitinases nas plantas micorrizadas pode auxiliar no estabelecimento da simbiose por atuar na degradação dos elicitores fúngicos, os quais ativariam os sistemas de defesa da planta. Alguns argumentos que suportam essa hipótese são: em culturas de células de tomate, arroz e alfafa, polimeros de $\mathrm{N}$-acetilglicosamina induzem respostas de defesa vegetal; elicitores relacionados a quitina também são liberados da parede do fungo $G$. intraradices; e tratamentos com elicitores de ectomicorrizas, reduzem a habilidade de indução de resposta de defesa vegetal (Salzer et al. 1997). 
Lambais \& Mehdy (1993) observaram menor taxa de supressão da atividade dessa hidrolase em raízes de plantas de feijoeiro micorrizadas e cultivadas nas condições de alto $\mathrm{P}$, comparadas às plantas cultivadas em condições de baixo $\mathrm{P}$.

A interação entre os fatores "fósforo" e "AS" também foi significativa $(p<0,05)$. A aplicação de AS, $8 \mathrm{SAP}$, induziu as atividades de quitinases somente nos tratamentos com alta concentração de $\mathrm{P}(\mathrm{p}<0,05)$ (Figura 16). Em condições de baixo $\mathrm{P}$ a presença do AS não afetou significativamente $(\mathrm{p}<0,05)$ as atividades de quitinases nas raízes (Figura 16).

Embora tenha sido demonstrado que o AS induz síntese de proteínas relacionadas à patogênese, os mecanismos que controlam essa indução não são totalmente conhecidos (Gaffney et al., 1993). Salzer et al. (2000) verificaram que os genes relacionados com a atividade de quitinases são distintos entre fungos patogênicos, rizóbio e fungos micorrízicos ( $G$. intraradices) em $M$. Truncatula, indicando um reconhecimento específico para o estabelecimento de cada interação.

\subsubsection{Efeito do ácido salicílico no padrão isoenzimático de quitinases}

Com o procedimento experimental utilizado, foi possível detectar somente uma isoforma de quitinase, provavelmente a isoforma básica (Figura 17). Tem sido demonstrado que feijão possui somente uma isoforma básica de quitinase, a qual é induzida por etileno e elicitores fúngicos (Broglie et al., 1986).

Atividades de quitinases foram detectadas em todos os tratamentos e épocas de colheitas. No entanto, o padrão de expressão, com base na análise densitométrica dos géis, foi alterado pela aplicação de $\mathrm{P}$, AS e inoculação com $G$. clarum. Na presença de G. clarum, as atividades de quitinases foram 2 a 3 vezes maiores do que nos demais tratamentos. Nos tratamentos com a aplicação de AS, as atividades de quitinases foram, em média, 1,5 vezes menores que nos tratamentos sem AS, principalmente 8 SAP. Os dados resultantes dessa análise indicam que o AS utilizado nesse experimento suprimiu a atividade dessa enzima. 
Em condições de baixo $P$ de plantas não-micorrizadas, as atividades de quitinases foram em média 1,5 vezes maiores do que em condições de alto $\mathrm{P}, 4$ e $6 \mathrm{SAP}$. Já, $8 \mathrm{SAP}$, as atividades de quitinases foram maiores na presença de alto $\mathrm{P}$. Em raizes colonizadas por G. clarum em condições de alto $\mathrm{P}$, as atividades de quitinases foram 1,2 vezes maiores do que os tratamentos com baixo P, 8 SAP. Já com a presença do AS, na mesma época de colheita, as atividades de quitinases foram 1,5 vezes maiores do que os tratamentos com baixo P. No geral, observa-se que ocorreu aumento da atividade de quitinases na maioria dos tratamentos com o desenvolvimento da planta, mas esse aumento foi mais intenso nas plantas micorrizadas em condições de alto $\mathrm{P}$. $\mathrm{O}$ fato pode ser referente ao aumento dos propágulos fúngicos e concomitante maior colonização micorrízica, de forma que a planta pode estar tentando controlar o nível de colonização intrarradicular.

Tem sido demonstrado que o gene da atividade de quitinase básica é expressado em altos níveis em raízes de tabaco e com efeito cumulativo com a idade das plantas. (Neale et al., 1990). David et al. (1998) também demonstraram que, a atividade de quitinase básica em tabaco, aumentou com a idade das plantas.

Embora o papel das quitinases no controle do desenvolvimento de MAs seja desconhecido, é provável que a indução de isoformas específicas iniba o crescimento fúngico intrarradicular, especialmente nas condições de alto P (Lambais \& Mehdy, 1995; 1998). Normalmente, a indução de atividades de quitinases está relacionada ao aumento da resistência à infecção por fungos patogênicos (Dassi et al., 1996; Guzzo \& Martins, 1996; Mauch \& Staehelin, 1989) e mecanismos semelhantes poderiam atuar em MAs nas condições de alta disponibilidade de $P$. 


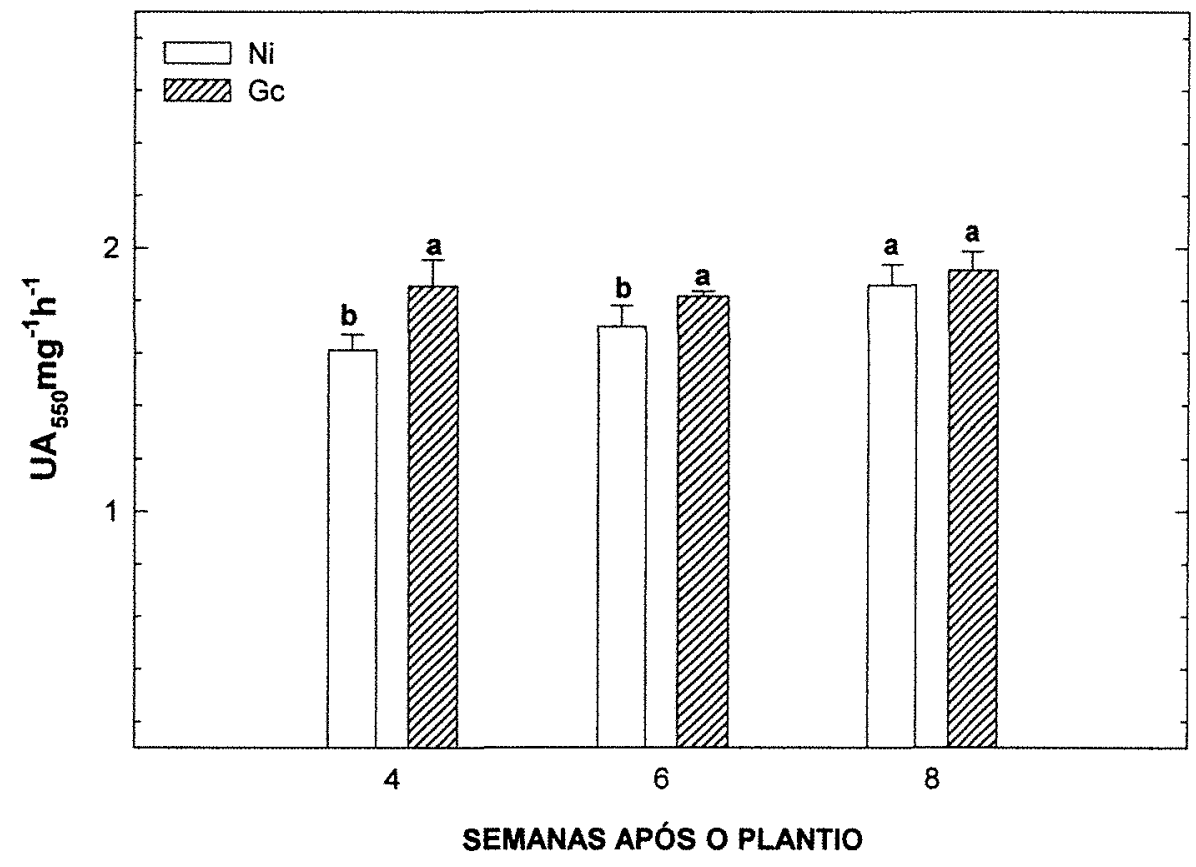

Figura 13 Atividade específica de quitinases em raizes de feijoeiro não-inoculadas (Ni) ou inoculadas com $G$. clarum $(\mathrm{Gc})$. As colheitas foram realizadas 4,6 e 8 semanas após plantio. Os dados são médias de 4 repetições \pm desvio padrão da média, e são expressos em Unidades de Absorbância à 550 nm (UA $\left.{ }_{550}\right)$ por mg de proteína por hora. As letras são usadas para comparar as médias entre os tratamentos em cada época de colheita. Médias seguidas da mesma letra não diferem estatisticamente (teste $t, \mathrm{p}<0,05$ ). 


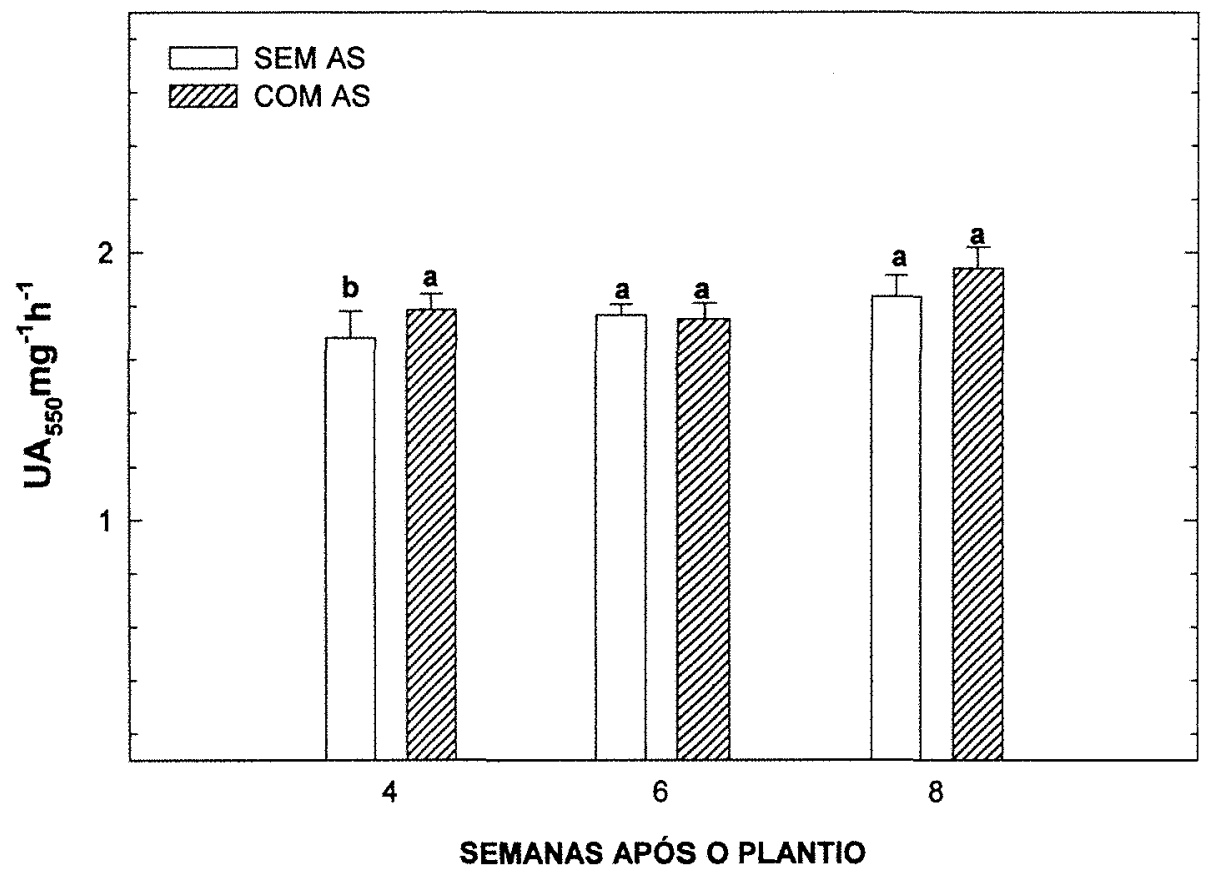

Figura 14 Atividade específica de quitinases em raízes de feijoeiro com ou sem aplicação de ácido salicílico (AS). As colheitas foram realizadas com 4, 6 e 8 semanas após plantio. Os dados são médias de 4 repetições \pm desvio padrão da média, e são expressos em Unidades de Absorbância à $550 \mathrm{~nm}\left(\mathrm{UA}_{550}\right)$ por mg de proteína por hora. As letras são usadas para comparar as médias entre os tratamentos em cada época de colheita. Médias seguidas da mesma letra não deferem estatisticamente (teste $t, \mathrm{p}<0,05$ ). 


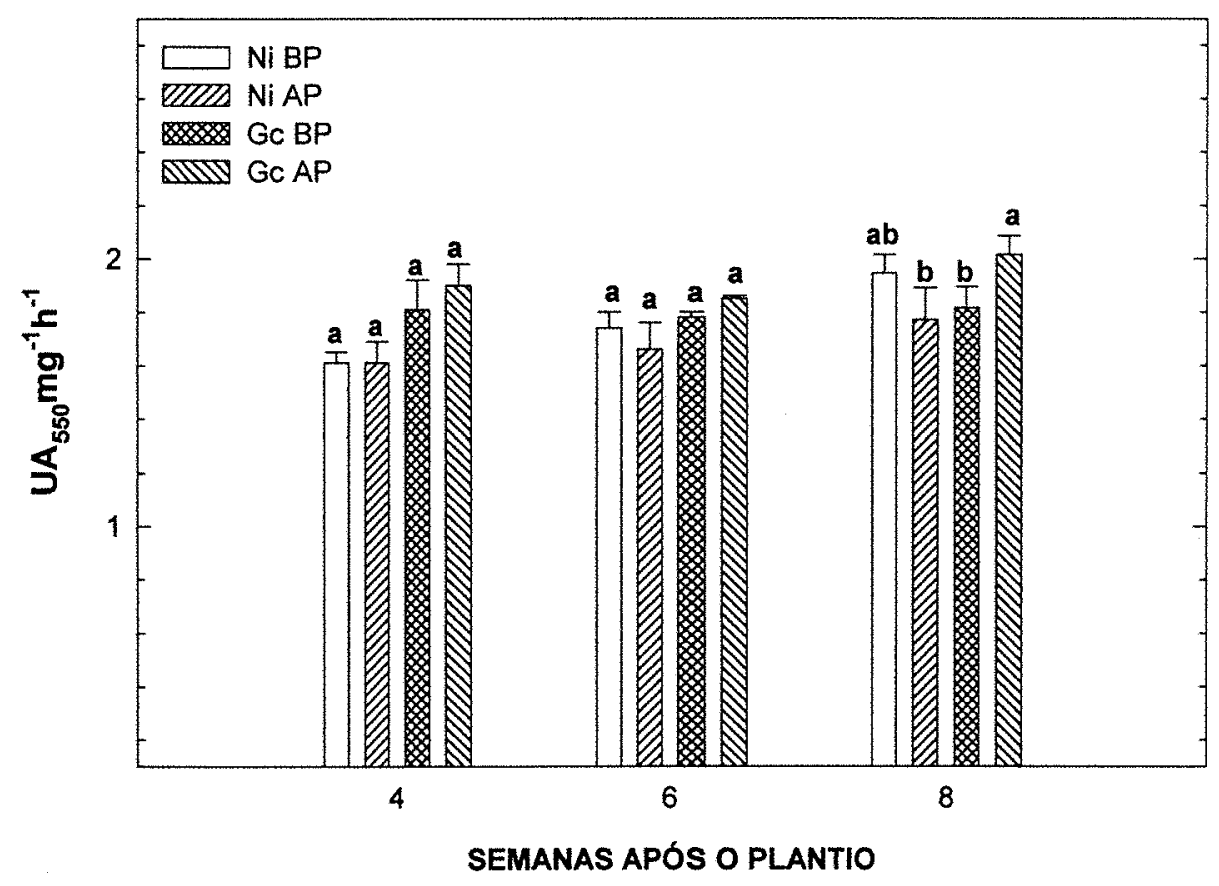

Figura 15 Atividade especifica de quitinases em raizes de feijoeiro não-inoculadas (Ni) ou inoculadas com G. clarum (Gc), em condições de baixo e alto P (BP, 20 ou AP, $150 \mathrm{mg} \mathrm{P} \mathrm{kg}^{-1}$ respectivamente). As colheitas foram realizadas $4,6 \mathrm{e}$ 8 semanas após plantio. Os dados são médias de 4 repetições \pm desvio padrão da média, e são expressos em Unidades de Absorbância à $550 \mathrm{~nm}$ $\left(\mathrm{UA}_{550}\right)$ por mg de proteína por hora. As letras são usadas para comparar as médias entre os tratamentos em cada época de colheita. Médias seguidas da mesma letra não deferem estatisticamente (teste $t, \mathrm{p}<0,05$ ). 


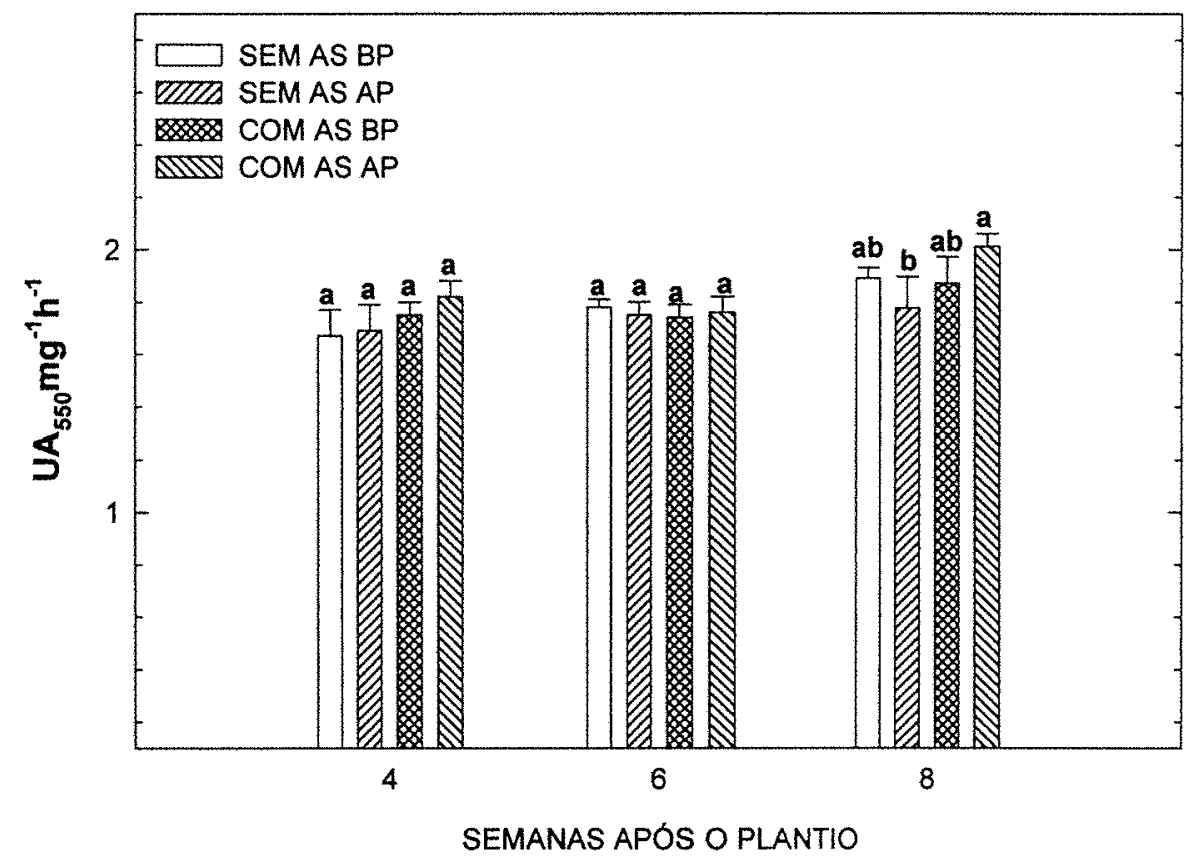

Figura 16 Atividade específica de quitinases em raizes de feijoeiro com ou sem aplicação de ácido salićlico (AS) em condições de baixo e alto P (BP, 20 ou $\mathrm{AP}, 150 \mathrm{mg} \mathrm{P} \mathrm{kg}^{-1}$ respectivamente). As colheitas foram realizadas com 4, 6 e 8 semanas após plantio. Os dados são médias de 4 repetições \pm desvio padrão da média, e são expressas em Unidades de Absorbância à $550 \mathrm{~nm}$ $\left(\mathrm{UA}_{550}\right)$ por mg de proteína por hora. As letras são usadas para comparar as médias entre os tratamentos em cada época de colheita. Médias seguidas da mesma letra não deferem estatisticamente (teste $t, \mathrm{p}<0,05$ ). 


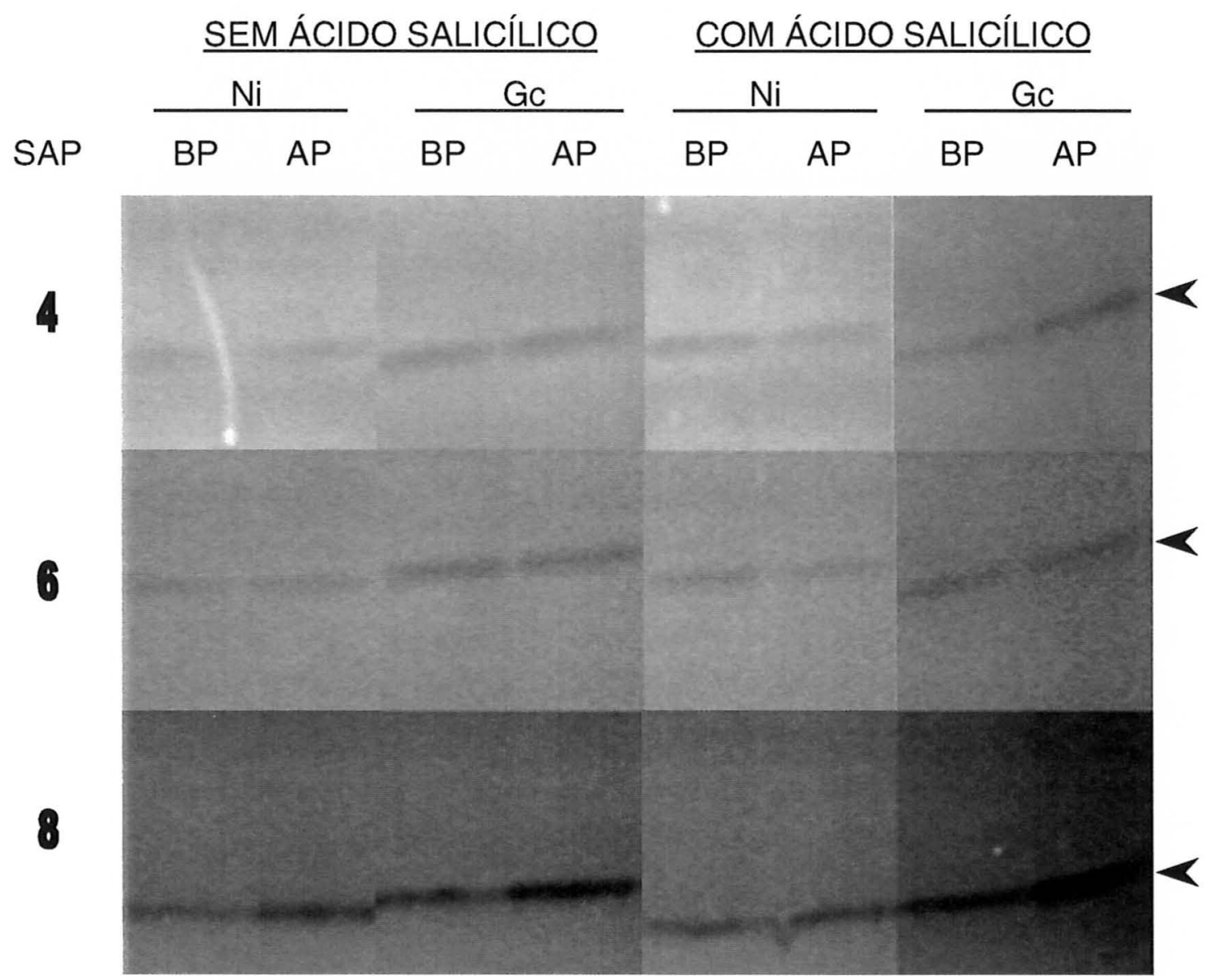

Figura 17. Caracterização isoenzimática de quitinases em gel de poliacrilamida nãodesnaturante. A eletroforese foi realizada com quantidades iguais de proteínas $(20 \mu \mathrm{g})$ de raízes de feijoeiro não-inoculadas (Ni) ou inoculadas com Glomus clarum $(\mathrm{Gc})$. As plantas foram cultivadas em condições de baixo ou alto $\mathrm{P}$ (BP, 20 ou AP, $150 \mathrm{mg} \mathrm{P} \mathrm{kg}^{-1}$ ). As foram colhidas 4, 6 e 8 semanas após o plantio (SAP). 


\subsubsection{Efeito da formononetina nas atividades de quitinases}

Atividades específicas de quitinases foram significativamente afetadas pela inoculação com G. clarum, pela aplicação da FOR e P. As atividades de quitinases foram $12 \%$ maiores em raízes micorrizadas, em relação aos controles não-inoculados, 4 e 8 SAP $(p<0,05)$ (Figura 18). Com 8 SAP, nos tratamentos sem aplicação de FOR, as atividades de quitinases foram maiores $13 \%$ do que nos tratamentos com a FOR $(p<0,05)$ (Figura 19). É provável que a FOR esteja relacionada com a supressão de quitinases, contribuindo para o aumento do crescimento fúngico intrarradicular, fato observado mais intensamente da 6 para a $8 \mathrm{SAP}$, especialmente sob condições de alto $\mathrm{P}$ (Figura 12B).

Das interações entre os diferentes fatores, somente a interação entre "fungo" e "P" com 8 SAP foi significativa estatisticamente $(p<0,05)$ (Figura 20). Nas plantas não-inoculadas, as atividades de quitinases foram significativamente maiores nas condições de baixo $P$, do que em condições de alto $P$, em cerca de $16 \%$.

Nos tratamentos inoculados com G. clarum não houve diferenças quanto a atividade de quitinases nas duas condições de fornecimento $P$. Era de se esperar que nas condições de alto $\mathrm{P}$ houvesse uma atividade de quitinases mais elevada, em conseqüência da ativação do sistema de defesa vegetal, como têm sido observado em outros experimentos (Neale et al., 1990). No entanto, a possibilidade da ocorrência de indução localizada de isoformas ácidas específicas não podem ser desconsideradas neste experimento, as quais poderiam estar sendo mais intensamente expressas nas condições de alto $P$.

\subsubsection{Efeito da formononetina no padrão isoenzimático de quitinases}

Com o procedimento experimental utilizado, foi possivel detectar somente uma isoforma de quitinase, provavelmente a isoforma básica (Figura 21). 
As atividades de quitinases foram detectadas em todos os tratamentos e épocas. Esse padrão de expressão foi alterado na presença ou ausência de FOR, fungos micorrízicos e doses de P. Nos tratamentos em geral, as atividades de quitinases foram maiores na última semana de colheita, principalmente nas condições de alto P. Os resultados demonstram que, na ausência de FOR e na presença do fungo micorrízico, as atividades foram 1,8 vezes maiores que nos tratamentos não-micorrizados. Nos tratamentos com a aplicação de FOR, as atividades de quitinases foram de 1,7 e 3 vezes maiores que nos tratamentos sem a presença do composto com 4 e 6 SAP, respectivamente. Com $8 \mathrm{SAP}$, não ocorreram diferenças, evidenciando que a dose utilizada pode ter sido suficiente para inibir ou atenuar o sistema de defesa vegetal contra as MAs. Em condição da dose utilizada de $\mathrm{P}$, as atividades de quitinases foram em média 1,4 vezes maiores em condições de baixo $\mathrm{P}$ nas duas primeira épocas de colheita e com $8 \mathrm{SAP}$ as atividades foram maiores na presença de alto $\mathrm{P}$, provavelmente pelo acúmulo de $\mathrm{P}$ na planta, ocasione uma atividade maior dessa enzima. Em raízes colonizadas por G. clarum em alto $\mathrm{P}$ foram maiores 1,2 vezes que o tratamento em condições de baixo P. Já com a presença da FOR em baixo P, a indução foi maior 2,2 vezes que o tratamento em alto $P$, e 1,4 vezes maior em condições de alto $P$ com 8 SAP, provavelmente devido a baixa absorção do $\mathrm{P}$ nas primeiras épocas de colheita. 


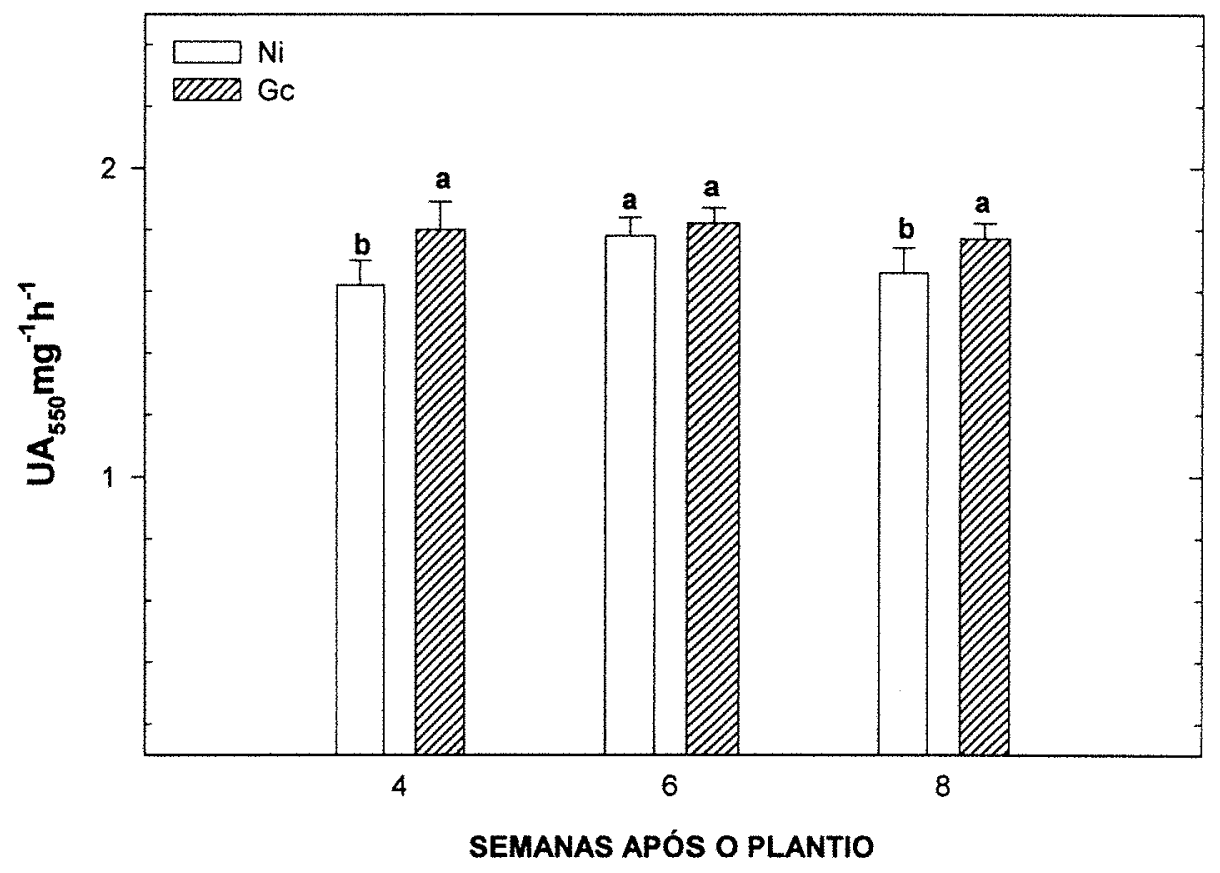

Figura 18. Atividades específicas de quitinases em raízes de feijoeiro não-inoculados (Ni) ou inoculados com G. clarum (GC). As colheitas foram realizadas com 4, 6 e 8 semanas após plantio. Os dados são médias de 4 repetições \pm desvio padrão da média, e são expressas em Unidades de Absorbância à $550 \mathrm{~nm}$ $\left(\mathrm{UA}_{550}\right)$ por mg de proteína por hora. As letras são usadas para comparar as médias entre os tratamentos em cada época de colheita. Médias seguidas de letras iguais são definidas estatisticamente (teste $t, \mathrm{p}<0,05$ ). 


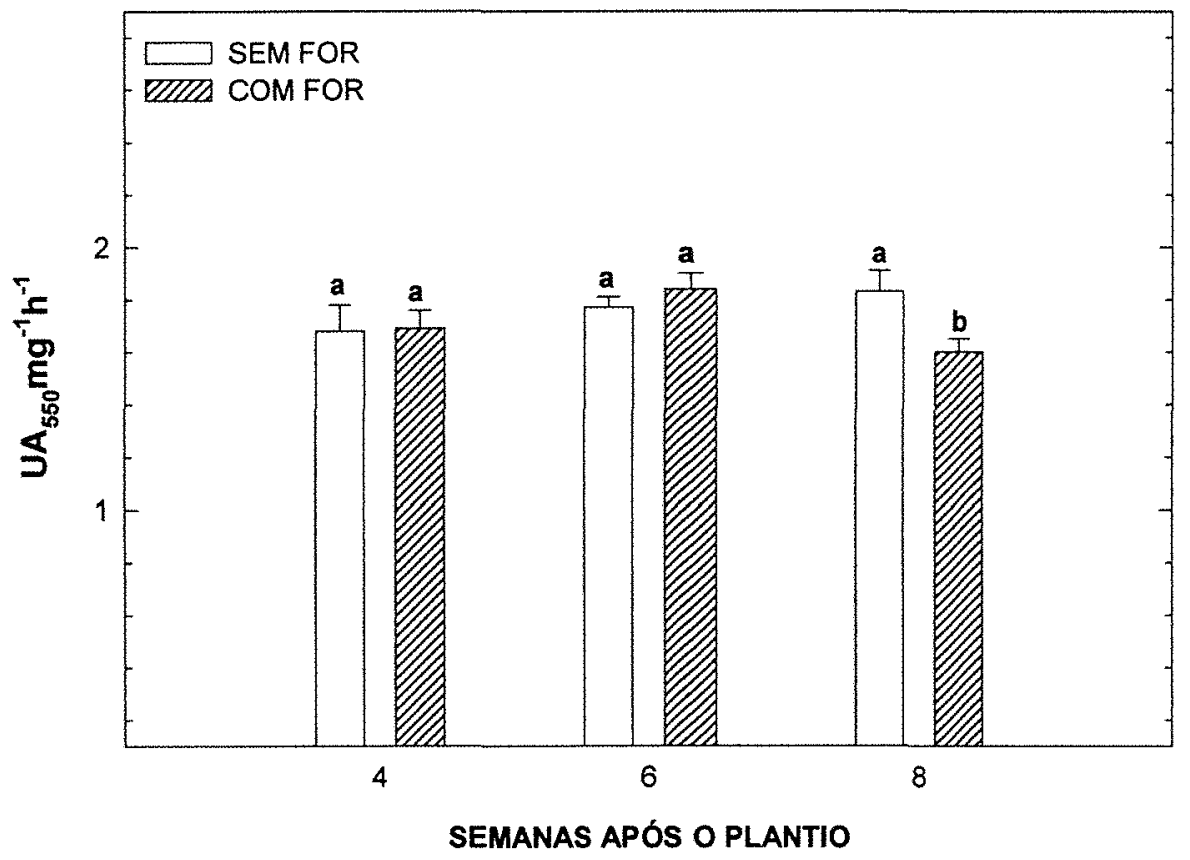

Figura 19. Atividades específicas de quitinase em raízes de feijoeiro com ou sem aplicação do composto fenólico formononetina (Mycoform, $120 \mathrm{mg} / \mathrm{mL}^{-1}$ ). As colheitas foram realizadas com 4, 6 e 8 semanas após plantio. Os dados são médias de 4 repetições \pm desvio padrão da média, e são expressas em Unidades de Absorbância à $550 \mathrm{~nm}\left(\mathrm{UA}_{550}\right)$ por mg de proteína por hora. As letras são usadas para comparar as médias entre os tratamentos em cada época de colheita. Médias seguidas de letras iguais são definidas estatisticamente (teste $t, \mathrm{p}<0,05$ ). 


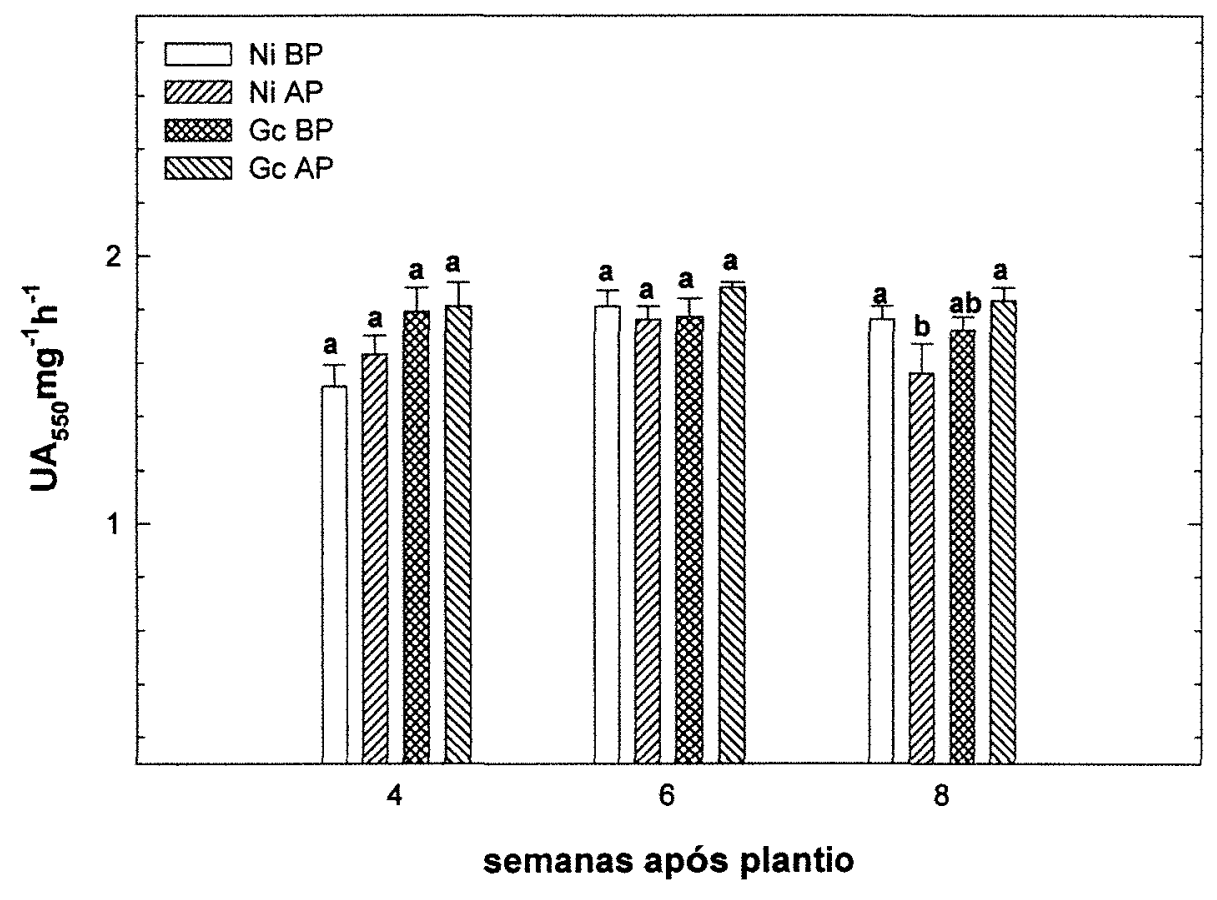

Figura 20. Atividades específicas de quitinase em raizes de feijoeiro colonizadas ou não por $G$ clarum e em condições de baixo ( $20 \mathrm{mg} \mathrm{Kg}^{-1}$ de substrato;) e alto $\mathrm{P}$ (150 $\mathrm{mg} \mathrm{Kg}^{-1}$ de substrato;). As colheitas foram realizadas 4, 6 e 8 semanas após plantio. Os dados são médias de 4 repetições \pm desvio padrão da média, e são expressas em Unidades de Absorbância à $550 \mathrm{~nm}\left(\mathrm{UA}_{550}\right)$ por $\mathrm{mg}$ de proteina por hora. As letras são usadas para comparar as médias entre os tratamentos em cada época de colheita. Médias seguidas de letras iguais são definidas estatisticamente (teste $t, \mathrm{p}<0,05$ ). 


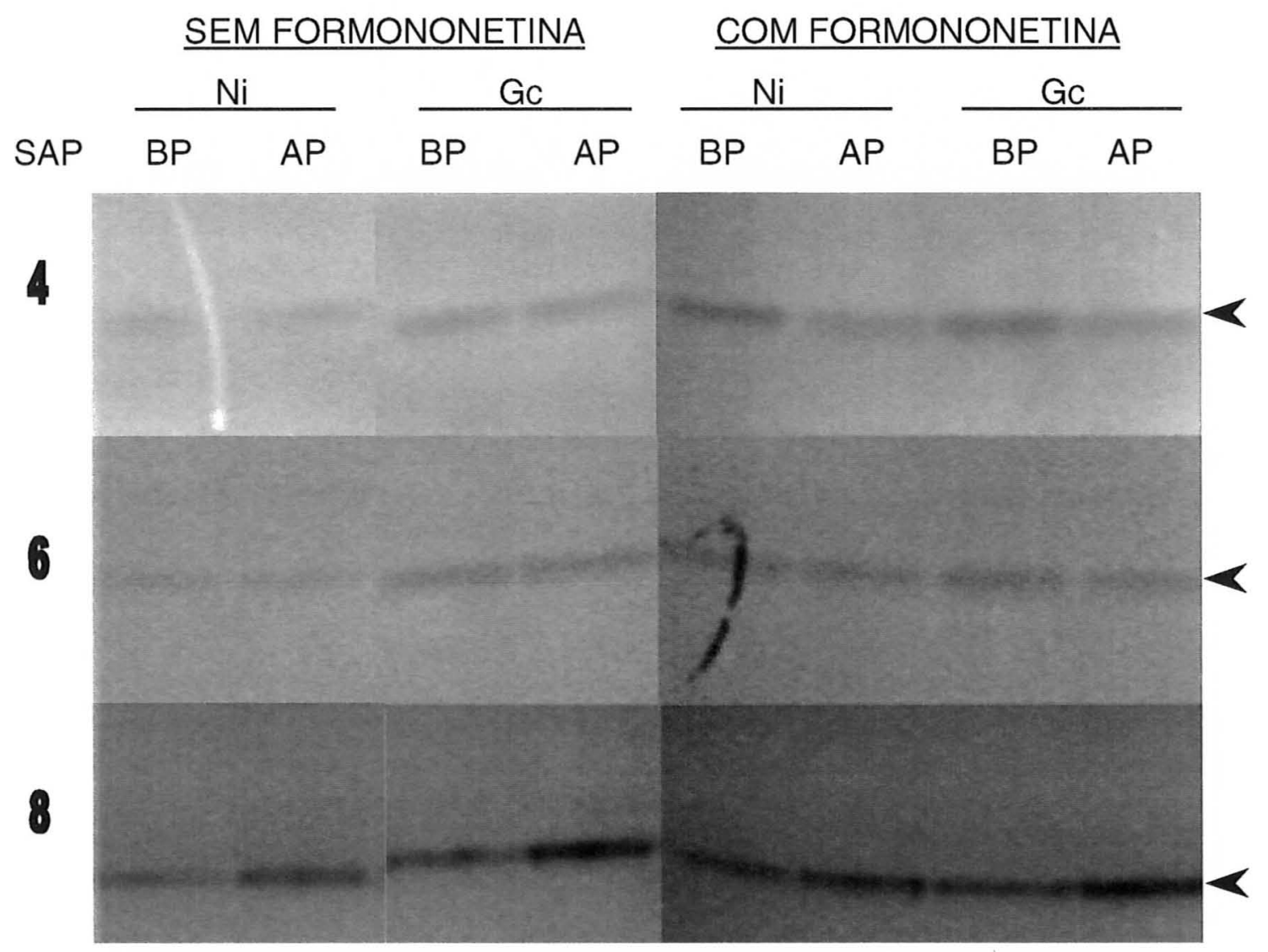

Figura 21. Caracterização isoenzimática de quitinases em gel de poliacrilamida nãodesnaturante. A eletroforese foi realizada com quantidades iguais de proteínas $(20 \mu \mathrm{g})$ de raízes de feijoeiro não-inoculadas (Ni) ou inoculadas com Glomus clarum $(\mathrm{Gc})$. As plantas foram cultivadas em condições de baixo ou alto $\mathrm{P}$ (BP, 20 ou AP, $150 \mathrm{mg} \mathrm{P} \mathrm{kg}^{-1}$ ). As foram colhidas 4, 6 e 8 semanas após o plantio (SAP). 


\subsection{Atividades e padrão isoenzimático de catalases}

\subsubsection{Efeito do ácido salicílico nas atividades de catalases}

$\mathrm{Na}$ ausência de AS, $4 \mathrm{SAP}$, as atividades de catalases nas raízes colonizadas por $G$. clarum, tanto em baixo quanto alto $\mathrm{P}$, foram aproximadamente 2 vezes maiores do que nas raízes não-inoculadas (Figura 22A). Em condições de alto P, 8 SAP, as raízes colonizadas por G. clarum apresentaram atividades de catalases 6 vezes maiores do que os outros tratamentos (Figura 22A). Esse fato pode estar relacionado com o aumento da taxa de colonização micorrízica no período entre 6 e $8 \mathrm{SAP}$, já que a indução de catalase pode estar associada ao mecanismo de controle da colonização das raízes pelo fungo G. clarum, por meio da degradação do $\mathrm{H}_{2} \mathrm{O}_{2}$, o qual poderia suprimir a ativação de genes de defesa da planta (Wu et al., 1997), possibilitando o crescimento fúngico intrarradicular.

$\mathrm{Na}$ presença de $\mathrm{AS}$ e alto $\mathrm{P}$, houve uma indução de aproximadamente 9 e 2 vezes da atividade de catalases nas raízes colonizadas por G. clarum, 4 e 8 SAP, respectivamente (Figura 22B), em relação às plantas não micorrizadas. Esses dados sugerem que AS induziu as atividades de catalases em raízes de feijoeiros micorrizadas, fato possivelmente resultante do processo de colonização micorrízica, visto que, tanto na ausência de micorrização, quanto na ausência de AS, as atividades foram bem menores. Em raízes micorrizadas em condições de alto $\mathrm{P}$, houve, com $6 \mathrm{SAP}$, indução de 7,5 vezes das atividades de catalases, em relação aos demais tratamentos, com posterior diminuição da atividade com 8 SAP. Nas condições de baixo P, as plantas micorrizadas apresentaram menor atividade de catalase em comparação com as plantas em condições de alto $\mathrm{P}$, exceto $4 \mathrm{SAP}$, quando apresentaram atividades semelhantes, porém ambas superiores que as atividades observadas nos tratamentos não inoculados. Essa maior atividade inicial de catalases, nas raízes das plantas micorrizadas, são possivelmente resultantes do processo de colonização radicular e estabelecimento da simbiose. O fato de maior atividade de catalases na presença do AS foi controverso, visto que era de se 
esperar uma diminuição de sua atividade. Segundo Ryals et al. (1996) foi proposto que o AS se liga e inativa a catalase, induzindo o acúmulo de $\mathrm{H}_{2} \mathrm{O}_{2}$ resultando na indução da resistência sistêmica adquirida. $\mathrm{Na}$ última época de colheita, as atividades de catalases foram menores, provavelmente pelo acúmulo do AS na planta, de modo que ocorreu uma supressão da atividade (Figura 22B). Ao passo em que a atividade de catalase diminui, era de se esperar uma redução da colonização intrarradicular, fato esse não ocorrido.

\subsubsection{Efeito do ácido salicílico no padrão isoenzimático de catalases}

A deteç̧ão de atividades de catalases em géis de poliacrilamida nãodesnaturante revelou a existência de uma única isoforma em raízes, independente da colonização pelo FMA (Figura 23). Resultados semelhantes foram observados por RiosRuiz (1998), em raízes de feijoeiro não-micorrizadas ou colonizadas por $G$. intraradices.

No geral, as raízes colonizadas por G. clarum apresentaram maiores atividades de catalases do que as raízes não-micorrizadas, tanto na ausência quanto na presença de AS, as quais diminuíram com o desenvolvimento das plantas (Figura 23). $\mathrm{Na}$ ausência de AS a atividade de catalases foram suprimidas 796 vezes em raízes de plantas não-micorrizadas com $6 \mathrm{SAP}$ em condições de alto $\mathrm{P}$ em relação aos tratamentos com baixo $P$.

Com 8 SAP, raízes colonizadas em condições de baixo $P$, as atividades

de catalases foram 50 vezes maiores do que em condições de alto P. A supressão das atividades de catalases pelo aumento da concentração de $P$ no solo é atenuada em raízes micorrizadas

Ao contrário do observado na ausência de AS, na presença de AS, a supressão de atividades de catalases em raizes não-micorrizadas e em condições de alto $\mathrm{P}$ não foi observada, exceto 4 SAP. Em raízes micorrizadas em condições de alto $\mathrm{P}$, a indução das atividades de 4,3 e 41,4 vezes, 6 e 8 SAP, respectivamente, foi observada. 
Comparando os resultados obtidos entre presença e ausência do AS, no geral, pode-se observar que a atividade de catalase foi maior nos tratamentos inoculados com FMA em condições de alta disponibilidade de $\mathrm{P}$ e na presença do AS. Os resultados demonstram que na última época de colheita, um provável acúmulo de AS nas raízes das plantas, pode ter inativado a atividade da enzima que não suprimiu a colonização intrarradicular. 


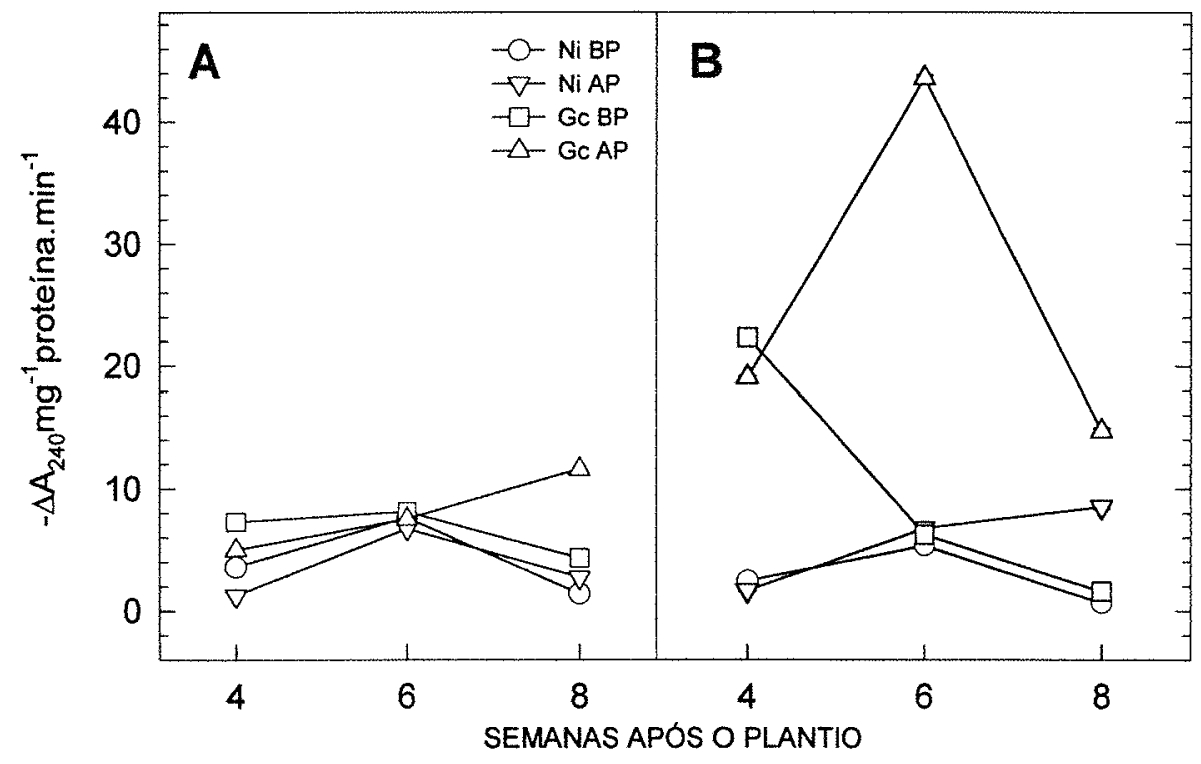

Figura 22. Atividades específicas de catalase em raízes de feijoeiro em condições de baixa (BP) e alta (AP) concentração de $\mathrm{P}$ (20 e $150 \mathrm{mg} \mathrm{P} \mathrm{kg}^{-1}$ de substrato). A: sem aplicação de ácido salicílico. B: com aplicação de ácido salicílico. Os dados são apresentados como variação da absorbância à $240 \mathrm{~nm}\left(\Delta \mathrm{A}_{240}\right)$ por mg de proteína por hora. Os dados representam médias de 4 repetições \pm desvio padrão da média. 


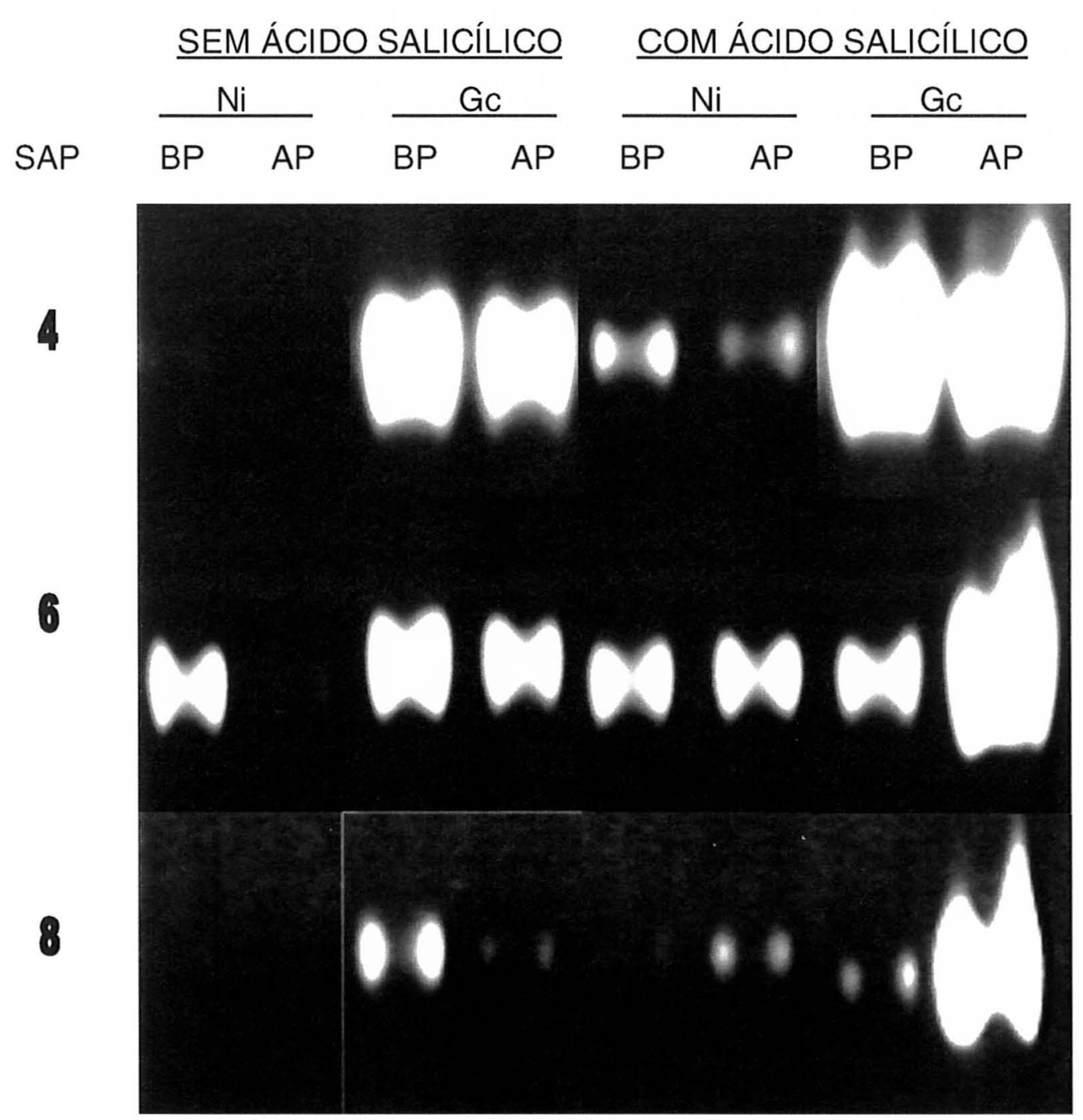

Figura 23. Caracterização isoenzimática de catalases em gel de poliacrilamida nãodesnaturante. A eletroforese foi realizada com quantidades iguais de proteínas $(30 \mu \mathrm{g})$ de raízes de feijoeiro não-inoculadas (Ni) ou inoculadoas por Glomus clarum (Gc). As plantas foram cultivadas em condições de baixo ou alto $\mathrm{P}$ (BP, 20 ou AP, $150 \mathrm{mg} \mathrm{P} \mathrm{kg}^{-1}$ ). As foram colhidas 4, 6 e 8 semanas após o plantio (SAP). 


\subsubsection{Efeito da formononetina nas atividades de catalases}

$\mathrm{Na}$ ausência de FOR, as atividades de catalases apresentam indução transiente durante o desenvolvimento da planta, e no geral, foram induzidas em raizes colonizadas por $G$. clarum, quando comparado com raízes não-inoculadas, tanto em condições de baixo quanto de alto P, 4 e 8 SAP (Figura 24A). Tanto em raizes nãomicorrizadas quanto micorrizadas, em condições de alto P com 4 SAP, as atividades de catalases foram suprimidas, 1,4 e 3,5 vezes, respectivamente, comparado com os controles em condições de baixo P (Figura 24A). Já, 8 SAP, em raízes micorrizadas sob condições de alto $\mathrm{P}$, as atividades específicas de catalases foram induzidas 2,9 vezes em relação ao tratamento sob condições de baixo P (Figura 24A). Raízes de plantas inoculadas com $G$. clarum em condições de alto $\mathrm{P}$, e não tratadas com FOR, 4 SAP, apresentaram atividade de catalases 5 vezes maior do que plantas não-micorrizadas de mesma condição de P (Figura 24A).

$\mathrm{Na}$ presença de FOR, o modelo de expressão de catalases em raízes não-micorrizadas foi comparável àquele obtida na ausência de FOR, isto é, indução transiente da atividade específica durante o desenvolvimento da planta (6 SAP).

Em condições de alto P, 4 SAP, em plantas micorrizadas, foram induzidas a atividade de catalases em 1,3 vezes em condições de baixo $P$, plantas nãomicorrizadas não apresentaram diferenças entre os tratamento (Figura 24B). Já as planta micorrizadas em condições de alto $\mathrm{P}$, as atividades foram 6 vezes menor que o tratamento não-micorrizado em condições de alto $\mathrm{P}$. Ao contrário, $6 \mathrm{SAP}$, raízes colonizadas por $G$. clarum e não-micorrizadas em condições de alto $\mathrm{P}$, apresentaram atividades de catalases, 3,6 e 2,9 vezes maiores, respectivamente, comparado aos tratamento em condições de baixa disponibilidade de P (Figura 24B).

Esses dados sugerem que a maior colonização micorrízica observada em raizes, sob condições de alto $\mathrm{P}$ e com FOR, comparando com alto $\mathrm{P}$ sem FOR, pode ser decorrente de um bloqueio da indução do sistema de defesa vegetal, pela degradação do $\mathrm{H}_{2} \mathrm{O}_{2}$, permitindo um maior crescimento fúngico intrarradicular. 


\subsubsection{Efeito da formononetina no padrão isoenzimático de catalases}

Como nas raizes tratadas com AS, somente uma isoforma de catalase foi detectada nos géis de poliacrilamida não-desnaturante (Figura 25). Os tratamentos sem aplicação de FOR foram idênticos aos tratamentos sem o AS, já que os controles foram comuns aos dois experimentos.

Em raízes não-micorrizadas e tratadas com $\mathrm{FOR}$, as atividades de catalases 5,8 e 200 vezes, 6 e $8 \mathrm{SAP}$, respectivamente, foram induzidas em condições de alto $\mathrm{P}$, comparado com baixo P. Em raízes inoculadas com G. clarum em condições de baixo P, 6 SAP as atividades de catalases, foram 4,3 vezes maiores sob condições de alto P. Já, $8 \mathrm{SAP}$, as atividades de catalases em raízes micorrizadas foram 43,7 vezes maiores sob condições de alto $\mathrm{P}$ comparado ao tratamento com baixo $\mathrm{P}$.

Entre os tratamentos não-micorrizados e micorrizados por G. clarum, 4 SAP, as atividades foram 66,4 vezes sob condições de baixo $P$ e 8,7 vezes sob condições de alto $\mathrm{P}$ maiores nos tratamentos micorrizados. Com 6 e 8 SAP, entre os tratamentos não-micorrizados e micorrizados em condições de baixo $\mathrm{P}$, ocorreu supressão das atividades de catalases em 1,4 vezes no tratamento inoculado com 6 SAP e indução de 2,7 vezes no tratamento inoculado com 8 SAP. Já em condições de alta disponibilidade de P, 6 e 8 SAP, ocorreu menor supressão da atividade de catalases, 1,9 e 1,6 vezes, respectivamente.

Comparando os tratamentos entre aplicação ou não de FOR, observouse que catalase foi induzida nos tratamentos com a presença de FOR não inoculada e principalmente em altas concentrações de $\mathrm{P}$ e todas as épocas. Nos tratamentos micorrizados em condições de alto $\mathrm{P}$, as atividades de catalases foram induzidas 1,1 vezes com 6 SAP e 121,9 vezes com 8 SAP na presença da FOR. Esse fato pode ser atribuído ao composto fenólico, que em condições de alta disponibilidade de $\mathrm{P}$, reduziu o efeito negativo à micorrização. 


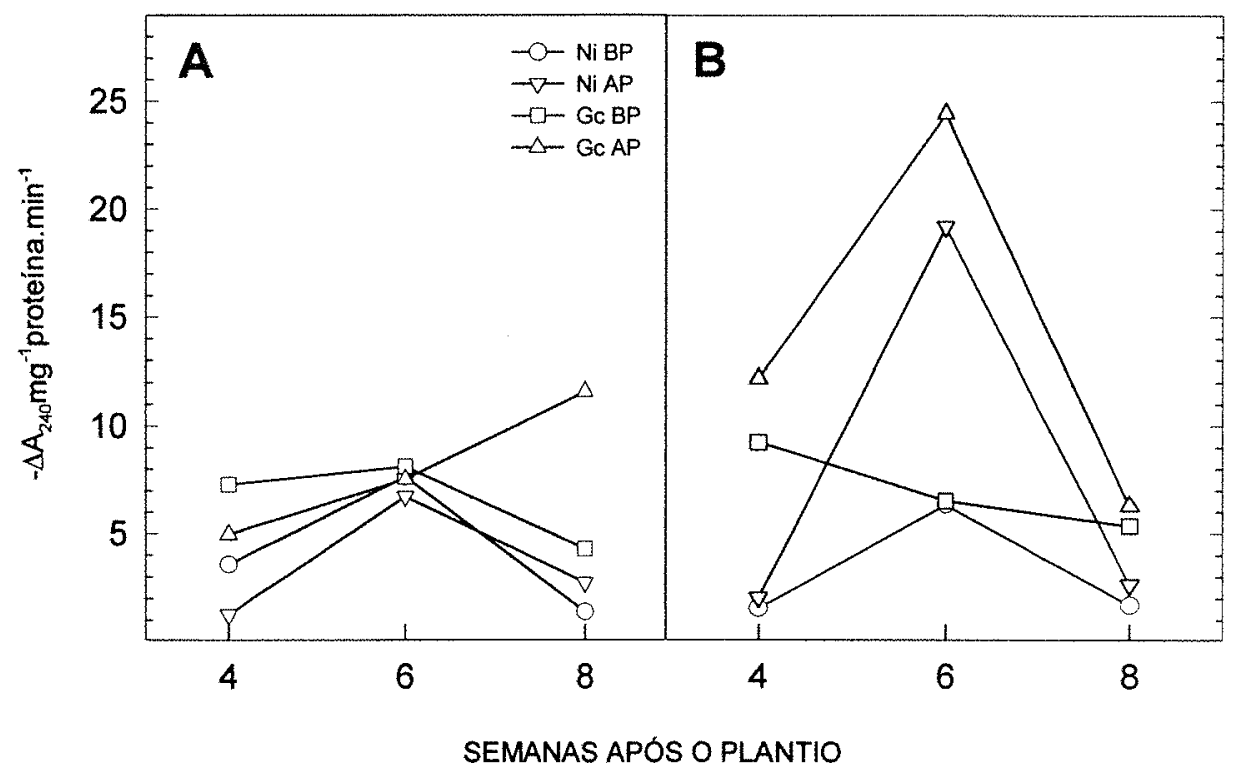

Figura 24. Atividades especificas de catalases em raizes de feijoeiro em condições de baixa (BP) e alta (AP) concentração de $\mathrm{P}$ (20 e $150 \mathrm{mg} \mathrm{P} \mathrm{kg}^{-1}$ de substrato). A: sem aplicação de formononetina e $\mathbf{B}$ : com aplicação da formononetina. Os dados são apresentados como variação da absorbância à $240 \mathrm{~nm}\left(\Delta \mathrm{A}_{240}\right)$ por mg de proteína por hora. Os dados representam médias de 4 repetições \pm desvio padrão da média. 


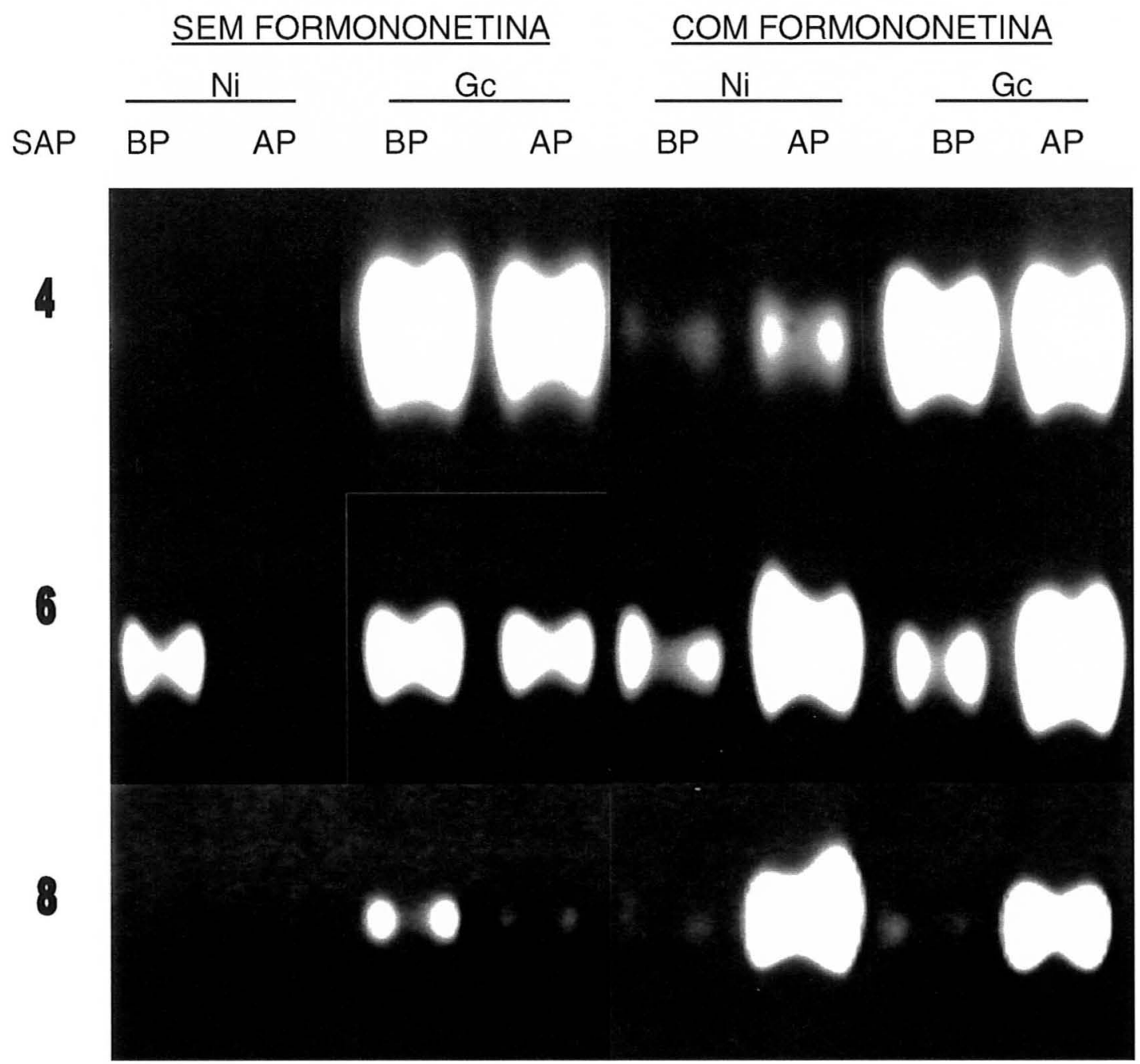

Figura 25. Caracterização isoenzimática de catalases em gel de poliacrilamida nãodesnaturante. A eletroforese foi realizada com quantidades iguais de proteínas $(20 \mu \mathrm{g})$ de raízes de feijoeiro não-inoculadas (Ni) ou inoculadoas por Glomus clarum (Gc). As plantas foram cultivadas em condições de baixo ou alto $\mathrm{P}$ (BP, 20 ou AP, $150 \mathrm{mg} \mathrm{P} \mathrm{kg}^{-1}$ ). As foram colhidas 4, 6 e 8 semanas após o plantio (SAP). 


\subsubsection{Efeito do ácido salicílico no perfil de proteínas totais}

Os perfis de proteinas totais em géis de poliacrilamida desnaturante podem ser vistas na Figura 26. A análise densitométrica dos géis revelou a presença de proteínas com massa molecular aparente (MMA) variando de 20 a $160 \mathrm{kDa}$.

Das proteínas com expressão diferencial em raízes de feijoeiro sob diferentes condições de cultivo, quatro foram selecionadas para análise mais detalhada (Tabela 1). As proteinas P1 (108 kDa), P2 (45 kDa), P3 (37 kDa) e P4 (28 kDa) representam 4,$7 ; 1,3 ; 5,2$ e 10,8 \% do total de proteínas, respectivamente (Tabela 1).

Os resultados demonstram que a proteína P1 foi induzida com 4 SAP no tratamento não-micorrizado em baixa concentração de $\mathrm{P}$ e no tratamento nãomicorrizado na presença do AS em condições de baixo P. Nos demais tratamentos e épocas de colheita, essa proteína foi suprimida.

Já a proteína $\mathrm{P} 2$, os resultados demonstram que ocorreu uma indução nos tratamentos Gc BP e Gc AS BP com $6 \mathrm{SAP}$, provavelmente essa indução pode estar relacionada a presença do fungo micorrízico em condições de baixa disponibilidade de P.

A proteína $\mathrm{P} 3$ demonstrou supressão em vários tratamentos e épocas de colheita, com exceção nos tratamentos Gc AP (8 SAP) e Gc AS BP (4 e 8 SAP), propondo que o fungo micorrizico pode induzir essa proteína, independentemente dos fatores conjugados, como concentração de $\mathrm{P}$ ou presença do AS.

Com a proteína $\mathrm{P} 4$, ocorreu baixa indução em todos os tratamentos não-micorrizados, na $4 \mathrm{SAP}$ e no tratamento $\mathrm{Ni} \mathrm{AS} \mathrm{BP}$ na $6 \mathrm{SAP}$, e supressão nos demais tratamentos e épocas de colheita, evidenciando que a presença do FMA pode suprimir essa proteína, independente aos outros fatore.

Esses dados sugerem que essas proteínas podem ter papel importante no controle do desenvolvimento de MAs, e devem ser melhor estudadas. 
Tabela 1: Alterações do proteoma de raízes de feijoeiros inoculados com G. clarum e tratados com ácido salicílico.

\begin{tabular}{ccccccccccc}
\hline Proteina & MMA & AR & & \multicolumn{7}{c}{ Expressão relativa $(\Delta \%)^{1}$} \\
\cline { 5 - 11 } & (kDa) & $(\%)$ & SAP & Ni AP & Ni AS BP & Ni AS AP & Gc BP & Gc AP & Gc AS BP & Gc AS AP \\
\hline P1 & 108 & 4,7 & 4 & $+4,1$ & $+19,1$ & $-19,1$ & $-21,4$ & $-33,8$ & $-59,6$ & $-52,3$ \\
& & & 6 & -67 & $-63,9$ & $-3,4$ & $-89,5$ & $-5,1$ & $-86,2$ & $-69,6$ \\
& & & 8 & $-91,1$ & $-80,4$ & nd & $-74,9$ & nd & $-89,6$ & $-82,3$ \\
P2 & \multirow{2}{*}{45} & 1,3 & 4 & $-30,8$ & $-31,6$ & $-33,2$ & $-4,4$ & $-8,7$ & $-5,5$ & $-23,2$ \\
& & & 6 & $+66,5$ & $+54,8$ & $-37,2$ & $+149,3$ & $+45,2$ & $+138,9$ & $+59,7$ \\
& & & 8 & $+18,9$ & $-2,2$ & $-24,4$ & $+15,1$ & $+54,5$ & $+63,9$ & $-16,5$ \\
P3 & \multirow{2}{*}{37} & 5,2 & 4 & $-12,8$ & $-4,1$ & $-8,7$ & $-63,5$ & -56 & $+3,9$ & $-76,4$ \\
& & & 6 & $-95,2$ & $-92,8$ & $-71,8$ & $-90,1$ & $-65,9$ & $-52,3$ & $-81,7$ \\
& & & 8 & $-24,9$ & $-44,5$ & $-21,2$ & $-18,1$ & $+2,4$ & $+17,3$ & $-28,5$ \\
P4 & \multirow{2}{*}{28} & 10,8 & 4 & $+10,6$ & $+6,8$ & $+0,3$ & $-56,7$ & $-63,2$ & $-27,7$ & $-76,5$ \\
& & & 6 & -92 & $-82,4$ & $-86,3$ & $-86,3$ & $-85,4$ & $-92,1$ & $-67,3$ \\
& & 8 & $-4,1$ & $+7,7$ & $-5,4$ & $-34,1$ & $-31,7$ & $-0,3$ & $-74,1$ \\
\hline
\end{tabular}

Tariação percentual calculado em relação à abundância de proteína no tratamento $\mathrm{Ni}$ $\mathrm{BP}$ em cada época de amostragem. MMA, massa molecular aparente; AR, abundância relativa; (\%) relativa ao total de proteína; $\mathrm{SAP}$, semanas após o plantio; $\mathrm{Ni}$, nãoinoculado; Gc, inoculado com Glomus clarum; BP, baixa concentração de P (20 mg P $\mathrm{kg}^{-1}$ de substrato); AP, alta concentração de $\mathrm{P}$ (150 $\mathrm{mg} \mathrm{P} \mathrm{kg}^{-1}$ de substrato); AS, com aplicação de ácido salicílico; nd, não-detectado. 


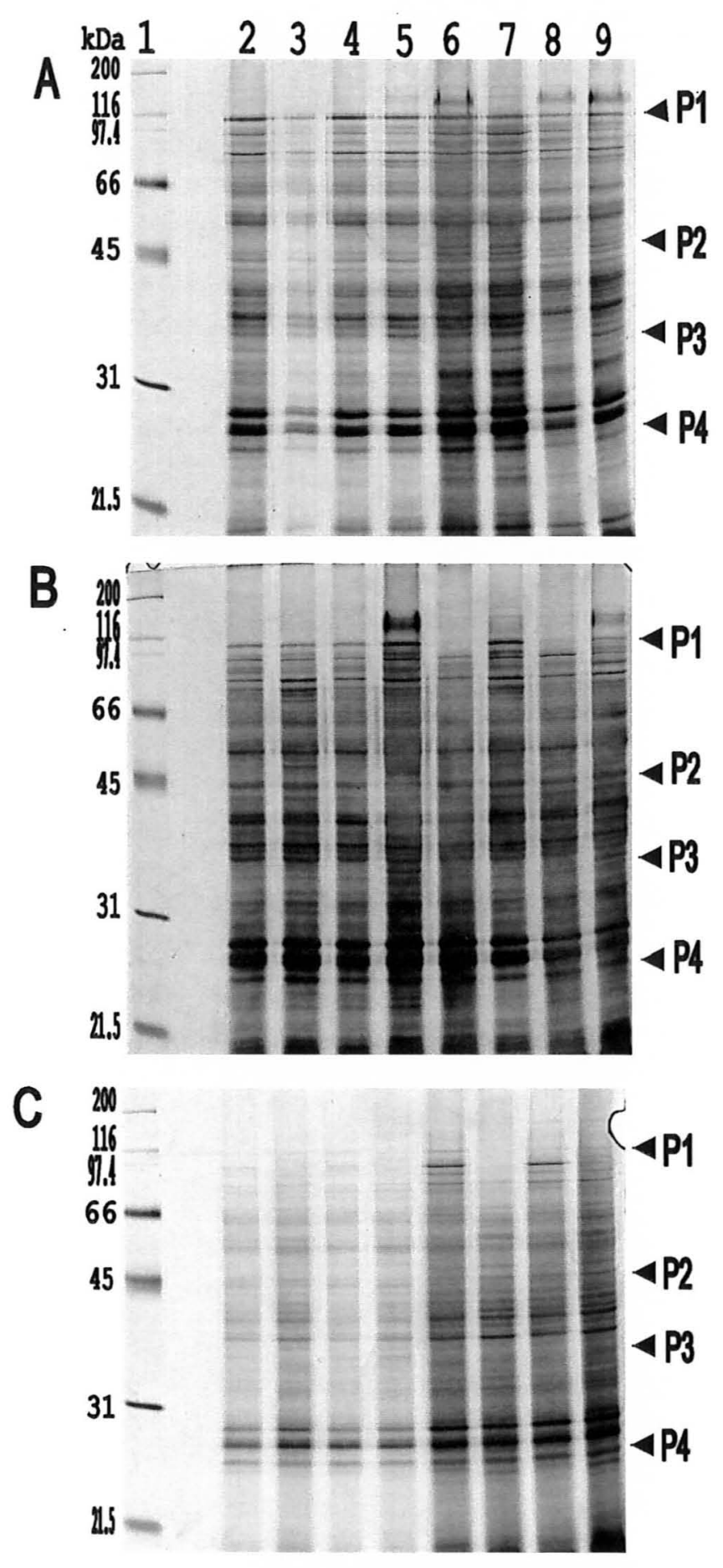

Figura 26 Caracterização de proteínas totais em géis de poliacrilamida desnaturante, aplicação de ácido salicílico e $5 \mu \mathrm{g}$ de proteína total por canaleta, onde $\mathbf{A}, 4$ SAP; B, 6 SAP e C, 8 SAP; 1 marcador de massa molecular; 2 Ni BP; 3 Ni AP; 4 Ni AS BP; 5 Ni AS AP; 6 Gc BP; 7 Gc AP; 8 Gc AS BP e 9 Gc AS AP. SAP, semanas após plantio; Ni, não-inoculado; Gc, Glomus clarum; BP, baixo $\mathrm{P}$ (20 $\mathrm{mg} \mathrm{kg}^{-1}$ de substrato); $\mathrm{AP}$, alto $\mathrm{P}$ (150 $\mathrm{mg} \mathrm{kg}^{-1}$ de substrato); AS, ácido salicílico. 


\subsubsection{Efeito da formononetina no perfil de proteínas totais}

Os perfis de proteínas totais em géis de poliacrilamida desnaturante podem ser vistas na Figura 27. A análise densitométrica dos géis revelou a presença de proteínas com MMA variando de 20 a $160 \mathrm{kDa}$.

Das proteínas com expressão diferencial em raízes de feijoeiro sob diferentes condições de cultivo, quatro foram selecionadas para análise mais detalhada (Tabela 2). As proteínas P1 (108 kDa), P5 (93,5 kDa), P3 (37 kDa) e P6 (25 kDa) representam 4,$5 ; 1,5 ; 4,3$ e $5,1 \%$ do total de proteínas de raízes de feijoeiro nãomicorrizadas e sob condições de baixo $\mathrm{P}$, respectivamente.

Os resultados demonstram que a proteína $\mathrm{P} 1$ demonstrou pouca indução nos tratamentos Gc BP com 4 SAP e no tratamento Gc FOR AP com 4 e 6 SAP. Os resultados diferem dos apresentados na Tabela 2, tal fato pode-se observar um resultado contrário ao descrito anteriormente, sendo a proteína suprimida no tratamento Ni AP. Outra supressão também pode ser observada no tratamento Ni FOR BP, se compararmos com tratamento Ni AS BP, evidenciando que nesse caso o AS induziu e a FOR suprimiu a referida proteína, demonstrando que os compostos fenólicos utilizados nesse experimento, podem modular a expressão diferencial dessas proteínas

A proteína $\mathrm{P} 5$, demonstrou grande indução principalmente no tratamento conjugado entre FMA e FOR em condições de alta concentração de P com 6 SAP. Sob condições de baixo $\mathrm{P}$, o tratamento com o fungo micorrízico e presença da FOR, os dados demonstram uma indução sucessiva no decorrer das coletas, provavelmente pelo fato do aumento da colonização micorrízica intrarradicular, pôde ocasionar essa indução.

Já a proteína $\mathrm{P} 3$ demonstrou indução principalmente em condições de baixa disponibilidade de $\mathrm{P}$, demonstrando que o $\mathrm{P}$ pode estar envolvido nessa indução/supressão.

Os resultados demonstram que a P6 foi suprimida na maioria dos tratamentos e épocas de colheitas e foi induzida principalmente nos tratamentos com a presença da FOR ou na ausência do composto em condições de alto P com 8 SAP. 
Esses dados sugerem que essa proteína pode estar envolvida no controle da colonização de raízes tratadas com FOR e fungos MAs. Outros experimentos serão necessários para determinar a função dessa proteína e seu papel no processo de desenvolvimento de MAs. 
Tabela 2: Alterações do proteoma de raizes de feijoeiros inoculadas com $G$. clarum e tratadas com formononetina.

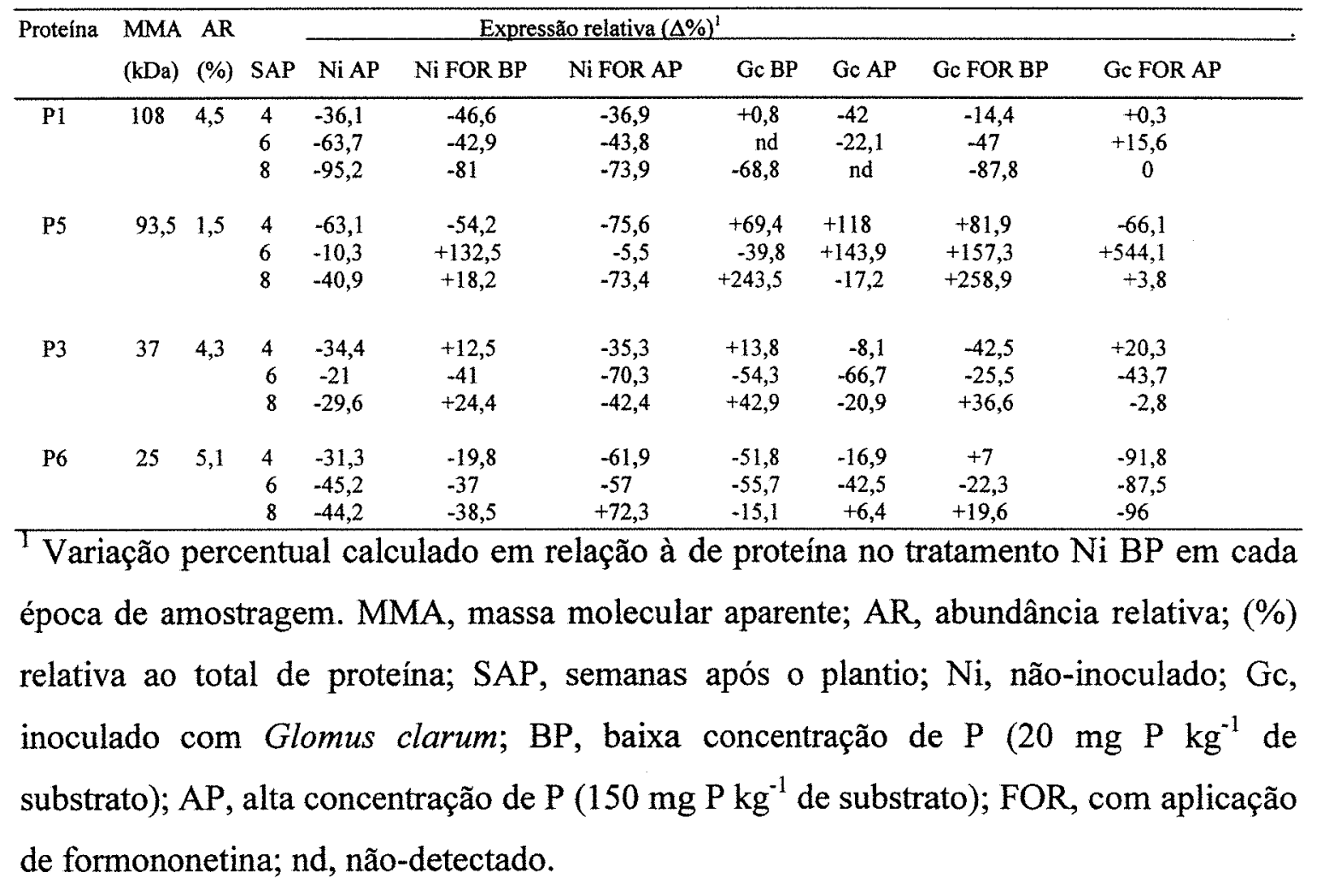



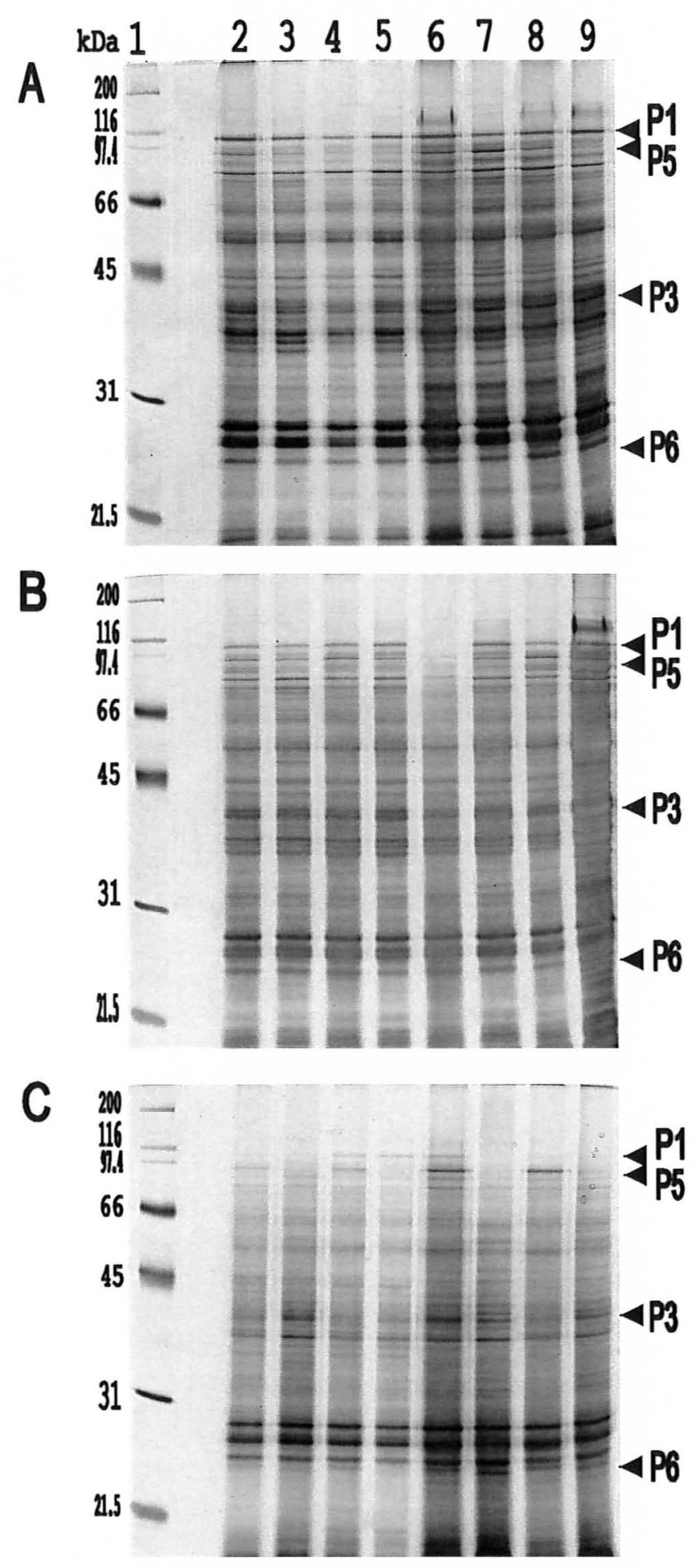

Figura 27 Caracterização de proteínas totais em géis de poliacrilamida desnaturante com aplicação de formononetina e $5 \mu \mathrm{g}$ de proteína total por canaleta, onde A, 4 SAP; B, 6 SAP e C, 8 SAP; 1 marcador de massa molecular; 2, Ni BP; 3, Ni AP; 4, Ni FOR BP; 5, Ni FOR AP; 6, Gc BP; 7, Gc AP; 8, Gc FOR BP e 9, Gc FOR AP. SAP, semanas após plantio; Ni, não-inoculado; Gc, Glomus clarum; BP, baixo P (20 $\mathrm{mg} \mathrm{kg}^{-1}$ de substrato); AP, alto P (150 mg $\mathrm{kg}^{-1}$ de substrato); FOR, formononetina. 


\section{CONCLUSÕES}

Os resultados obtidos demonstram que:

a) Em condições de alto $P$, a colonização intrarradicular foi inibida, e as atividades de quitinases e catalases de modo geral foram induzidas.

b) G. clarum induziu a produção de MSPA e MSSR principalmente na última época de colheita, e as atividades de quitinases e catalases.

c) O AS não interferiu na produção da matéria seca da parte aérea e do sistema radicular, e não inibiu a colonização micorrízica em condições de alta disponibilidade de $P$.

d) No geral, o AS induziu as atividades de catalases.

e) A FOR não interferiu na produção de MSPA e MSSR, e induziu a colonização intrarradicular em condições de alto $P$.

f) No geral, a FOR induziu as atividades de catalases, principalmente em condições de alto $P$.

g) Os proteomas de raízes de feijoeiros colonizados por G. clarum apresentaram expressão diferencial de proteínas específicas. Essa expressão foi afetada pela adição de P, AS ou FOR, e também pelo estágio de desenvolvimento da simbiose. 


\title{
REFERÊNCIAS BIBLIOGRÁFICAS
}

\begin{abstract}
ABBOTT, L.K.; ROBSON, A.D.; BOER, G. The effect of phosphorus on the formation of hyphae in soil by the vesicular-arbuscular mycorrhizal fungus, Glomus fasciculatum. The New Phytologist, v.97, n.3, p.437-446, 1984.
\end{abstract}

AEBI, H. Catalase in vitro. Methods in Enzymology, v.105, p.121-126, 1984.

AUH, C.; SCANDALIOS, J.G. Spatial and temporal responses of the maize catalases to low temperature. Physiologia Plantarum, v.101, p.149-156, 1997.

AGRIOS, G.N. Plant pathology. London: Academic Press, 1997. cap.5, p.93-112: How plants defend themselves against pathogens.

ANCILLO, G.; WITTE, B.; SCHMELZER, E.; KOMBRINK, E. A distinct member of the basic (class I) chitinase gene family in potato is specifically expresse in epidermal cells. Plant Molecular Biology, v.39, p.1137-1151, 1999.

ANTUNES, V.; CARDOSO, E.J.B.N. Growth and nutrient status of citrus plants as influenced by mycorrhiza and phosphorus application. Plant and Soil, v.131, p.11$19,1991$.

BÉCARD, G.; TAYLOR, L.P.; DOUDS JR, D.D; PFEFFER, P.E.; DONER, L.W. Flavonoids are not necessary plant signal compounds in arbuscular mycorrhizal symbioses. Molecular Plant-Microbe Interactions, v.8, n.2, p.252-258, 1995. 
BETHLENFALVAY, G.J.; BROWN, M.S.; PACOVSKY, R.S. Parasitic and mutualistic association between a mycorrhizal fungus and soybean: development of the host plant Phytopathology, v.72, p.894-897, 1982.

BOL, J.F.; LINTHORST, H.J.M. Plant pathogenesis-related proteins induced by virus infection. Annual Review of Phytopathology, v.28, p.113-138, 1990.

BRADFORD, M.M. A rapid and sensitive method for the quantitation of microgram quantities of protein utilizing the principle of protein-dye binding. Analytical Biochemistry, v.72, n.1/2, p.248-254, 1976.

BROGLIE, K.E, GAYNOR, J.J, BROGLIE, R.M. Ethylene-regulated gene expression: molecular cloning of the genes encoding an endochitinase from Phaseolus vulgaris. Proceedings of the National Academy of Sciences of the United States of America, v.83, p.6820-6824, 1986.

BURGGRAAF, A.J.P.; AND BERINGER, J.E. Absence of nuclear DNA synthesis in vesicular-arbuscular mycorrhizal fungi during in vitro development. The New Phytologist, v.111, p.25-33, 1989.

CHEN, Z.; SILVA, H.; KLESSIG, D.F. Active oxygen species in the induction of plant systemic acquired resistance by salicylic acid. Science, v.262, p.1883-1886, 1993.

COSTA, H.S.; RIOS-RUIZ, W.F.; LAMBAIS, M.R. Ácido salicílico inibe a formação de micorrizas arbusculares e modifica a expressão de quitinases e $\beta-1,3$ glucanases em raízes de feijoeiro. Scientia Agrícola, v.57,n.1,p.19-25, 2000.

COLOZZI-FILHO, A.; SIQUEIRA, J.O. Micorrizas vesículo-arbusculares em mudas de cafeeiro. I Efeitos de Gigaspora margarita e adubação fosfatada no crescimento e nutrição. Revista Brasileira de Ciência do Solo, v.10, p.199-205, 1986. 
DASSI, B.; DUMAS GAUDOT, E.; ASSELIN, A.; RICHARD, C.; GIANINAZZI, S. Chitinase and $\beta-1,3$-glucanase isoforms expressed in pea roots inoculated with arbuscular mycorrhizal or pathogenic fungi. European Journal of Plant Pathology, v.102, n.1, p.105-108, 1996.

DAVID, R.; ITZHAKI, H.; GINZBERG, I.; GAFNI, Y.; GALILI, G.; KAPULNIK, Y. Suppression of tobacco basic chitinase gene expression in response to colonization by the arbuscular mycorrhizal fungus Glomus intrarradices. Molecular PlantMicrobe Interactions, v. 11, n.6 p.489-497, 1998.

DRUMM, H.; SCHOPFER, P. Effect of phytochrome on development of catalase activity and isoenzyme pattern in mustard (Sinapis alba L.) seedling. A reinvestigation. Planta, v.120, p.13-30, 1974.

FRIES, L.L.M.; PACOVSKY, R.S.; SAFIR, G.R.; KAMINSKI, J. Phosphorus effect on phosphatase activity in endomycorrhizal maize. Physiologia Plantarum, v.103, p.162-171, 1998.

FRUGOLI, J.A.; ZHONG, H.H.; NUCCIO, M.L.; McCOURT, P.; McPEEK, M.A.; THOMAS, T.L.; McCLUNG, C.R. Catalase is encoded by a multigene family in Arabidopsis thaliana (L.) Heynh. Plant Physiology, v.112, p.327-336, 1996.

GAFFNEY, T.; FRIEDRICH, L.; VERNOOIJ, B. Requirement of salicylic acid for the induction of systemic acquired resistance. Science, v.261, p.754-756, 1993.

GIANINAZZI, S. Vesicular-arbuscular (endo-) mycorrhizas: cellular, biochemical and genetic aspects. Agriculture Ecosystems Environment, v.35, n.2-3, p.105-119, 1991. 
GIANINAZZI-PEARSON， V.; BRANZANTI， B.; GIANINAZZI， S. "In vitro" enhancement of spore germination in early hyphal growth of a vesicular-arbuscular mycorrhizal fungus by host root exudates plants and flavonoids. Symbiosis, v.7, p.243-255, 1989.

GIOVANNETTI, M.; MOSSE, B. An evaluation of techniques for measuring vesicular arbuscular mycorrhizal infection in roots. The New Phytologist, v.84, p.489-500, 1980.

GUZZO, S.D.; MARTINS, E.M.F. Local and systemic induction of $\beta-1,3$-glucanase and chitinase in coffee leaves protected against Hemileia vastatrix by Bacillus thuringiensis. Journal of Phytopathology, v.144, p.449-454, 1996.

HAVIR, E.A.; McHALE, N.A. Biochemical and developmental characterization of multiple forms of catalase in tobacco leaves. Plant Physiology, v.84, p.450-455, 1987.

HOLTMAN, W.L.; GRAAFF, A.M.; LEA, P.J.; KIJNE, J.W. Light-dependent expression of two catalase subunits in leaves of barley seedlings. Journal of Experimental Botany, v.49, nº 325, p.1303-1306, 1997.

INGOLD, C.T.; HUDSON, H.J. The biology of fungi. (Sixth edition):Chapman \& Hall, 1993, cap.11, p.183-196.

INVAM. htpp://invam.caf.wvu.edu, 2000.

JAKOBSEN, I. Transport of phosphorus and carbon in VA mycorrhizas. In: VARMA, A. \& HOCK, B. (eds.) Mycorrhiza: structure, function, molecular biology and biotechnology. Berlin, Springer-Verlag, 1995. p.297-324. 
JANDA, T.; SZALAI, G.; TARI, I.; PÁLDI, E. Hydroponic treatment with salicylic acid decreases the effects of chilling injury in maize (Zea mays L.) plants. Planta, v.208, p.175-180, 1999.

KOIDE, R.T.; LI, M. On host regulation of the vesicular-arbuscular mycorrhizal symbiosis. The New Phytologist, v.114, p.59-74, 1990.

LAMBAIS, M.R. Aspectos bioquímicos e moleculares da relação fungo-planta em micorrizas arbusculares. In: SIQUEIRA, J.O. Avanços em fundamentos e aplicação de micorrizas. Lavras - MG: UFLA - DCS e DCF, 1996. cap.2, p.5-38.

LAMBAIS, M.R.; CARDOSO, E.J.B.N. Avaliação da germinação de esporos de fungos micorrízicos vesículo-arbusculares e da colonização micorrízica de Stylosanthes guianensis em solo ácido e distrófico. Revista Brasileira de Ciência do Solo, v.12, p.249-255, 1988.

LAMBAIS, M.R.; CARDOSO, E.J.B.N. Germinação de esporos e crescimento do tubo germinativo de fungos micorrízicos vesículo-arbusculares em diferentes concentrações de alumínio. Revista Brasileira de Ciência do Solo, v.13, p.151$154,1989$.

LAMBAIS, M.R.; MEHDY, M.C. Supression of endochitinase, $\beta-1,3$-endoglucanase, and chalcone isomerase expression in bean vesicular-arbuscular mycorrizal roots under different soil phosphate conditions. Molecular Plant-Microbe Interactions, v.6, p.75-83, 1993.

LAMBAIS, M.R.; MEHDY, M.C. Differential expression of defense-related genes in arbuscular mycorrhiza. Canadian Journal of Botany, v.73, supl.1, p.533-540, 1995. 
LAMBAIS, M.R.; MEHDY, M.C. Soybean roots infected by Glomus intraradices strains differing in infectivity exhibit differential chitinase and $\beta-1,3$ glucanase expression. The New Phytologist, v.134, n.3, p.531-538, 1996.

LAMBAIS, M.R.; MEHDY, M.C. Spatial distribuition of chitinases and $\beta-1,3$-glucanase transcripts in bean arbuscular mycorrhizal roots under low and high soil phosphate conditions. The New Phytologist, v.140, n.1, p.33-42, 1998.

LEITE, B.; RONCATO, L.D.B.; PASCHOLATI, S.F.; LAMBAIS, M.R. Reconhecimento e transdução de sinais moleculares em interações planta-fungos patogênicos. Revisão Anual de Patologia de Plantas, v.5, p.235-281, 1997.

MAUCH, F.; STAEHELIN, L.A. Functional implications of the subcellular localization of ethylene-induced chitinase and $\beta$-1,3-glucanase in bean leaves. The Plant Cell, v.1, n.4, p. 447-457, 1989.

MEHDY, M.C. Active oxygen species in plant defense against pathogens. Plant Physiology, v.105, n.2, p.467-472, 1994.

NAIR, M.G.; SAFIR, G.R.; SIQUEIRA, J.O. Isolation and identification of vesicular and arbuscular mycorrhiza-stimulatory compounds from clover (Trifolium repens) roots. Applied and Environmental Microbiology, v.57, p.434-439, 1991.

NEALE, A.D.; WAHLEITHNER, J.A.; LUND, M.; et al. Chitinase, $\beta$-1,3-glucanase, osmotin and extensin are expressed in tobacco explants during flower formation. Plant Cell, v.2, p.673-684, 1990. 
NEUHAUS, J.M.; AHL-GOY, P.; HINZ, U.; FLORES, S.; MEINS, F. High-level expression of tobacco chitinase gene in Nicotiana sylvestris. Susceptiblity of transgenic plants to Cercospora nicotianae infection. Plant Molecular Biology, v.16, n.1, p.141-151, 1991.

NOGUEIRA, A.V. As micorrizas e o excesso de metais. In. SIQUEIRA, J.O. (ed) Avanços em fundamentos e aplicação de micorrizas. Lavras: Universidade Federal de Lavras/DCS e DCF. 1996, p. 135-174.

NOGUEIRA, M.A.; CARDOSO, E.J.B.N. Produção de micélio externo por fungos micorrízicos arbusculares e crescimento da soja em função de doses de fósforo. Revista Brasileira de Ciência do Solo. v.24, p.329-338, 2000.

OTA, Y.; ARIO, T.; HAYASHI, K.; NAKAGAWA, T.; HATTORI, T.; MAESHIMA, M.; ASAHI, T. Tissue-specific isoforms of catalase subunits in castor been seedlings. Plant Cell Physiology, v.33, p.225-232, 1992.

PASCHOLATI, S.F.; LEITE, B. Hospedeiro: mecanismos de resistência. In: BERGAMIN FILHO, A.; KIMATI, H.; AMORIM, L. (Ed.) Manual de fitopatologia: princípios e conceitos. 3. ed. São Paulo: Agronômica Ceres, 1995. v.1, cap.22, p.417-753.

PHILLIPS, J.M.; HAYMAN, D.S. Improved procedures for clearing roots and staining parasitic and vesicular-arbuscular mycorrhizal fungi for rapid assessment of infection. Transactions of the British Mycological Society, v.55, n.1, p.158-162, 1970.

RAO, M.V.; PALIYATH, G.; ORMROD, D.P.; MURR, D.P.; WATKINS, C.B. Influence of salicylic acid on $\mathrm{H}_{2} \mathrm{O}_{2}$-metabolizing enzymes: salicylic acid-mediate damage requires $\mathrm{H}_{2} \mathrm{O}_{2}$. Plant Physiology, v.115, n.1, p.137-149, 1997. 
RATNAYAKE, M.; LEONARD, R.T.; MENGE, J.A. Root exudation in relation to supply of phosphorus and its possible relevance to mycorrhizal infection. The New Phytologist, v.81, p.543-552, 1978.

REMY, W.; TAYLOR, T.N.; HANS, H.; KERP, H. Four hundred-million-year-old vesicular arbuscular mycorrhizae. Proceedings of the National Academy of Sciences of the United States of America, v.91. p.11841-11843, 1994.

RIOS-RUIZ, W.F. Estudo de atividades enzimáticas envolvidas na geração e degradação de espécies ativas de oxigênio durante o desenvolvimento de micorrizas arbusculares. Piracicaba, 1998. 48p. Dissertação (Mestrado) - Escola Superior de Agricultura "Luiz de Queiroz" Universidade de São Paulo.

ROMERO, A.G.F.; SIQUEIRA, J.O. SOUZA, F.M. Isoflavonóide formononetina na colonização micorrízica da soja (Glicine max L. Merril) em solo com doses crescentes de fósforo. In: FERTBIO 98, Caxambú - MG, 1998. 797p.

RYALS, J.A.; NEUENSCHWANDER, U.H.; WILLITS, M.G.; MOLINA, A.; STEINER, H.Y.; HUNTER, M.D. Systemic acquired resistance. The Plant Cell, v.8, n.10, p.1809-1819, 1996.

SALZER, P.; BONANOMI, A.; BEYER, K.; et al. Differential expression of eight chitinase genes in Medicago truncatula roots during mycorrhiza formation, nodulation and pathogen infection. Molecular Plant-Microbe Interactions, v.13, p.763-777, 2000.

SALZER, P; HÜBNER, B.; SIRRENBERG, A.; HAGER, A. Differential effect of purified spruce chitinases and $\beta-1,3$-glucanases on the activity of elicitors from ectomycorrhizal fungi. Plant Physiology, v.114, p. 957-968, 1997. 
SAS INSTITUTE. SAS user's guide: release 6,03. Cary, 1988. 1028p.

SCHACHTMAN, D.P.; REID, R.J.; AYLING, S.M. Phosphorus uptake by plants: from soil to cell. Plant Physiology, v.116, p.447-453, 1998.

SILVA JÚNIOR, J.F; SIQUEIRA, J.O. Colonização micorrizica e crescimento da soja com diferentes fungos e aplicação do isoflavonóide formononetina. Pesquisa Agropecuária Brasileira, v.33, n.6, p.953-959, 1998.

SIMON, L.; BOUSQUET, J.; LEVESQUE, R.C.; LALONDE, M. Origin and diversification of endomycorrhizal fungi and coincidence with vascular land plants. Nature, v.363, p.67-69, 1993.

SIQUEIRA, J.O. Nutritional and edaphic factors affecting spore germination, germ tube growth and root colonization by the vesicular-arbuscular mycorrhizal fungi. $\mathrm{PhD}$ Thesis. University of Florida, Gainesville. 124. 1983.

SIQUEIRA, J.O.; BROWN, D.G.; SAFIR, G.R.; NAIR, M.G. Field application of the VA mycorrhiza stimulating isoflavonoid formononetin (Rhizotropin ${ }^{\mathrm{TM}}$ ) on corn and soybean in Braszil. In: The International Symposium on Management of Mycorrhizas, Perth, 1992. p.132.

SIQUEIRA, J.O.; COLOZZI-FILHO, A. Micorrizas vesículo-arbusculares em muda de cafeeiro. II. Efeito do fósforo no estabelecimento e funcionamento da simbiose. Revista Brasileira de Ciência do Solo. v.10, p.207-211, 1986.

SIQUEIRA, J.O.; FRANCO, A.A. Biotecnologia do solo: fundamentos e perspectivas. Brasília:MEC. ABEAS; Lavras: ESAL, FAEP, p.125-177, 1988. 
SIQUEIRA, J.O.; NAIR, M.G.; HAMMERSCHMIDT, R.; SAFIR, G.R. Significance of phenolic compounds in plant-soil-microbial systems. Critical Reviews in Plant Science, v. 10, p.63-121, 1991.

SIQUEIRA, J.O.; SAFIR, G.R.; NAIR, M.G. Stimulation of vesicular-arbuscular mycorrhiza formation and growth of white clover by flavonoid compounds. The New Phytologist, v.118, p.87-93, 1991.

SMITH, S.E.; READ, D.J. Mycorrhizal symbiosis: Vesicular-arbuscular mycorrhizas. London: Academic Press, 1997. section 1, p.11-160.

SPANU, P.; BOLLER, T.; LUDWIG, A.; WIEMKEN, A.; FACCIO, A.; BONFANTEFASOLO, P. Chitinase in mycorrhizal Allium porrum: regulation and localization. Planta, v.177, p.447-455, 1989.

SUBBA, N.S. Soil microorganisms and plant growth:Science Publishers Inc, 1995, cap.17, p.287-298: Mycorrhiza.

TRUDEL, J.; ASSELIN, A. Detection of chitinase activity after polyacrylamide gel electrophoresis. Analytical Biochemistry, v.178, p.362-366, 1989.

TSAI, S.M.; PHILLIPS, D.A. Flavonoids released naturally from alfafa promote development of symbiotic Glomus spore in vitro. Applied and Environmental Microbiology, v.57, n.5, p.1485-1488, 1991.

TSAI, S.M.; ROSSETO, R. Transformações microbianas do fósforo. In: CARDOSO, J.B.N.; TSAI, S.M.; NEVES, M.C.P. Microbiologia do solo. Campinas - SP, 1992. Sociedade Brasileira de Ciência do Solo. cap.17, p.231-242. 
VIEIRA, A.; AND GLENN, M.G. DNA content of vesicular-arbuscular mycorrhizal fungal spores. Mycologia, v.82, p.263-267, 1990.

VOLPIN, H.; ELKIND, Y.; OKON, Y.; KAPULNIK, Y. A vesicular arbuscular mycorrhizal fungus (Glomus intraradix) induces a defense response in alfafa roots. Plant Physiology, v.104, n.2, p.638-689, 1994.

WILLIAMSON, J.D.; SCANDALIOS, J.G. Response of the maize catalases and superoxide dismutases to cercosporin-containing fungal extracts: the pattern of catalase response in scutella is stage specific. Physiologia Plantarum, v.88, p.159$166,1993$.

WIRTH, A.; WOLF, E.R. Dye-labeled substrates for the assay and detection of chitinase and lysozyme activity. Journal of Microbiological Methods, v.12, p.197-205, 1990.

WOODBURY, W.; SPENCE, A.K.; STAHMANN, M.A. An improved procedure using ferrycianide for detecting catalase isozymes. Analytical Biochemistry, v.44, n.1, p.301-305, 1971 .

WU, G.; SHORTT, B.J.; LAWRENCE, J.L.; FITZSIMMONS, K.C.; LEVINE, E.B.; RASKIN, I.; SHAH, D.M. Activation of host defense mechanisms by elevated production of $\mathrm{H}_{2} \mathrm{O}_{2}$ in transgenic plants. Plant Physiology, v.115, n.2, p.427-435, 1997. 


\section{APÊNDICE 1}

\section{SUGESTÕES}

Após a obtenção da expressão de proteínas totais em géis de poliacrilamida, é possível que se faça:

$>$ Isolamento das proteínas que sofreram modificações conforme os tratamentos e épocas de colheita;

$>$ A reamplificação do cDNA dessa proteína pela reação de PCR;

$>$ A clonagem dos cDNAs e análise das seqüências obtidas para determinação de homologia com outras seqüências armazenadas em banco de dados;

$>$ Desenvolver plantas trangênicas ou mutantes com expressões diferenciais a proteína em questão;

$>$ Após os resultados, poderá avaliar o funcionamento desta proteína em relação aos tratamentos utilizados, como a simbiose, níveis de fosfato, enzimas reguladoras desta simbiose e compostos fenólicos utilizados. 


\section{APÊNDICE 2}

Resultados obtidos com aplicação de ácido salicílico

Análise estatística da matéria seca da parte aérea $(\mathrm{p}<0,05)$.

\begin{tabular}{lcccc|ccc|ccc}
\hline & \multicolumn{4}{c|}{ 4 SAP } & \multicolumn{3}{|c|}{ 6 SAP } & \multicolumn{3}{|c}{ 8 SAP } \\
\hline Trat./interação & GL & QM & F & Pr>f & QM & F & Pr>f & QM & F & Pr $>$ f \\
\hline Fungo & 1 & 0,061 & 0,21 & 0,653 & 1,080 & 6,84 & $\mathbf{0 , 0 1 5}$ & 45,936 & 88,68 & $\mathbf{0 , 0 0 0}$ \\
AS & 1 & 3,524 & 11,90 & $\mathbf{0 , 0 0 2}$ & 0,000 & 0,01 & 0,944 & 0,016 & 0,03 & 0,861 \\
P (fósforo) & 1 & 1,940 & 6,55 & $\mathbf{0 , 0 1 7}$ & 0,042 & 0,27 & $0,611 \mid$ & 4,205 & 8,12 & $\mathbf{0 , 0 0 9}$ \\
Fungo/AS & 1 & 0,036 & 0,12 & 0,729 & 0,101 & 0,64 & 0,431 & 0,255 & 0,49 & 0,489 \\
Fungo/P & 1 & 0,000 & 0,00 & 0,995 & 0,924 & 5,85 & $\mathbf{0 , 0 2 3} \mid$ & 2,989 & 5,77 & $\mathbf{0 , 0 2 4}$ \\
AS/P & 1 & 0,009 & 0,03 & 0,857 & 0,344 & 2,18 & 0,152 & 0,361 & 0,70 & 0,412 \\
Fungo/AS/P & 1 & 0,049 & 0,17 & 0,686 & 0,266 & 1,69 & 0,206 & 0,208 & 0,40 & 0,532
\end{tabular}

Os valores em negrito representam diferenças significativas.

Análise estatística da matéria seca do sistema radicular $(\mathrm{p}<0,05)$.

\begin{tabular}{lcccc|ccc|ccc}
\hline & \multicolumn{5}{c}{ 4 SAP } & \multicolumn{3}{|c|}{ 6 SAP } & \multicolumn{3}{|c}{$8 \mathrm{SAP}$} \\
\hline Trat./interação & GL & QM & F & Pr>F & QM & F & Pr>F & QM & F & Pr>F \\
\hline Fungo & 1 & 0,003 & 0,12 & 0,730 & 0,687 & 18,39 & $\mathbf{0 , 0 0 0}$ & 3,531 & 22,23 & $\mathbf{0 , 0 0 0}$ \\
AS & 1 & 0,075 & 2,69 & 0,114 & 0,907 & 24,29 & $\mathbf{0 , 0 0 0}$ & 0,000 & 0,01 & 0,941 \\
P (fósforo) & 1 & 0,136 & 4,89 & $\mathbf{0 , 0 3 7}$ & 0,468 & 12,52 & $\mathbf{0 , 0 0 1}$ & 3,899 & 24,55 & $\mathbf{0 , 0 0 0}$ \\
Fungo/AS & 1 & 0,006 & 0,23 & 0,638 & 0,969 & 25,94 & $\mathbf{0 , 0 0 0} \mid 0,350$ & 2,21 & 0,150 \\
Fungo/P & 1 & 0,044 & 1,58 & 0,220 & 0,434 & 11,63 & $\mathbf{0 , 0 0 2} \mid 1,509$ & 9,50 & $\mathbf{0 , 0 0 5}$ \\
AS/P & 1 & 0,033 & 1,19 & 0,287 & 0,024 & 0,66 & 0,424 & 0,031 & 0,20 & 0,658 \\
Fungo/AS/P & 1 & 0,004 & 0,15 & 0,699 & 1,076 & 28,80 & $\mathbf{0 , 0 0 0} \mid 0,034$ & 0,22 & 0,646
\end{tabular}

Os valores em negrito representam diferenças significativas. 
Resultados obtidos com aplicação de formononetina

Análise estatística da matéria seca da parte aérea $(\mathrm{p}<0,05)$.

\begin{tabular}{|c|c|c|c|c|c|c|c|c|c|c|}
\hline & \multicolumn{4}{|c|}{4 SAP } & \multicolumn{3}{|c|}{$6 \mathrm{SAP}$} & \multicolumn{3}{|c|}{$8 \mathrm{SAP}$} \\
\hline Trat./interação & GL & QM & $\mathrm{F}$ & $\operatorname{Pr}>\mathrm{f}$ & $\mathrm{QM}$ & $\mathrm{F}$ & $\operatorname{Pr}>\mathrm{f}$ & QM & $\mathrm{F}$ & $\operatorname{Pr}>\mathrm{f}$ \\
\hline Fungo & 1 & 0,000 & 0,00 & 0,962 & 0,861 & 2,25 & 0,147 & 59,268 & 74,20 & 0,000 \\
\hline FOR & 1 & 1,159 & 3,77 & 0,064 & 0,016 & 0,04 & 0,837 & 1,995 & 2,50 & 0,127 \\
\hline$P$ (fósforo) & 1 & 0,411 & 1,34 & 0,259 & 0,687 & 1,79 & 0,193 & 4,255 & 5,33 & 0,030 \\
\hline Fungo/FOR & 1 & 0,169 & 0,55 & 0,465 & 0,184 & 0,48 & 0,495 & 0,172 & 0,22 & 0,646 \\
\hline Fungo/P & 1 & 0,042 & 0,14 & 0,713 & 0,564 & 1,47 & 0,237 & 1,526 & 1,91 & 0,179 \\
\hline FOR/P & 1 & 0,425 & 1,38 & 0,251 & $\mid 0,200$ & 0,52 & 0,477 & 0,346 & 0,43 & 0,516 \\
\hline Fungo/FOR/P & 1 & 0,187 & 0,61 & 0,443 & 0,093 & 0,24 & 0,626 & 0,901 & 1,13 & 0,299 \\
\hline
\end{tabular}

Os valores em negrito representam diferenças significativas.

Análise estatística da matéria seca do sistema radicular $(\mathrm{p}<0,05)$.

\begin{tabular}{|c|c|c|c|c|c|c|c|c|c|c|}
\hline \multirow[b]{2}{*}{ Trat./interação } & \multirow[b]{2}{*}{ GL } & \multicolumn{3}{|c|}{$4 \mathrm{SAP}$} & \multicolumn{3}{|c|}{$6 \mathrm{SAP}$} & \multicolumn{3}{|c|}{$8 \mathrm{SAP}$} \\
\hline & & $\overline{\mathrm{QM}}$ & $F$ & $\mathrm{Pr}>\mathrm{F}$ & $\overline{Q M}$ & $\bar{F}$ & $\operatorname{Pr}>\mathrm{F}$ & QM & $F$ & $\operatorname{Pr}>\mathrm{F}$ \\
\hline Fungo & 1 & 0,239 & 2,38 & 0,136 & 0,017 & 0,04 & 0,845 & 1,121 & 10,63 & 0,003 \\
\hline FOR & 1 & 0,326 & 3,24 & 0,085 & $\mid 0,192$ & 0,44 & 0,513 & $\mid 0,055$ & 0,52 & 0,476 \\
\hline P (fósforo) & 1 & 0,003 & 0,03 & 0,856 & $\mid 0,017$ & 0,04 & 0,845 & | 0,559 & 5,30 & $\mathbf{0 , 0 3 0}$ \\
\hline Fungo/FOR & 1 & 0,261 & 2,59 & 0,120 & $\mid 0,000$ & 0,00 & 0,970 & 0,052 & 0,49 & 0,489 \\
\hline Fungo/P & 1 & 0,020 & 0,20 & 0,656 & 2,142 & 4,91 & $\mathbf{0 , 0 3 6}$ & $\mid 0,161$ & 1,53 & 0,228 \\
\hline FOR/P & 1 & 0,243 & 2,42 & 0,133 & $\mid 0,505$ & 1,16 & 0,293 & | 1,098 & 10,42 & 0,003 \\
\hline Fungo/FOR/P & 1 & 0,175 & 1,74 & 0,199 & $\mid 0,054$ & 0,12 & 0,727 & $\mid 1,026$ & 9,73 & 0,004 \\
\hline
\end{tabular}

Os valores em negrito representam diferenças significativas. 
Análise estatística da colonização intraradicular, com aplicação de AS $(p<0,05)$

\begin{tabular}{lcccc|ccc|ccc}
\hline & \multicolumn{4}{c|}{ 4 SAP } & \multicolumn{3}{|c|}{ 6 SAP } & \multicolumn{3}{|c}{ 8 SAP } \\
\hline Trat./interação & GL & QM & F & Pr $>$ F & QM & F & Pr>F & QM & F & Pr>F \\
\hline AS & 1 & 165,7 & 1,71 & 0,215 & 1284 & 10,89 & $\mathbf{0 , 0 0 6}$ & 16,1 & 0,35 & 0,941 \\
P (fósforo) & 1 & 467,7 & 4,83 & $\mathbf{0 , 0 4 8}$ & 5539 & 46,96 & $\mathbf{0 , 0 0 0}$ & 5895 & 128,4 & $\mathbf{0 , 0 0 0}$ \\
AS/P & 1 & 108,8 & 1,12 & 0,310 & 180,6 & 1,53 & 0,239 & $\mid 24,1$ & 0,53 & 0,482 \\
\hline
\end{tabular}

Os valores em negrito representam diferenças significativas.

Análise estatística da colonização intraradicular, com aplicação de FOR $(p<0,05)$.

\begin{tabular}{lcccc|ccc|cc|c}
\hline & \multicolumn{4}{c}{ 4 SAP } & \multicolumn{3}{|c|}{ 6 SAP } & \multicolumn{3}{c}{8 SAP } \\
\hline Trat/interação & GL & QM & F & Pr>F & QM & F & Pr>F & QM & F & Pr>F \\
\hline FOR & 1 & 16,52 & 1,97 & 0,186 & 37,6 & 0,16 & 0,695 & 70,5 & 0,13 & 0,720 \\
P (fósforo) & 1 & 677,5 & 80,65 & $\mathbf{0 , 0 0 0}$ & 4204 & 17,91 & $\mathbf{0 , 0 0 1}$ & 1321 & 2,51 & 0,139 \\
FOR/P & 1 & 36,36 & 4,33 & 0,059 & 14,8 & 0,06 & 0,805 & 2055 & 3,91 & 0,071 \\
\hline
\end{tabular}

Os valores em negrito representam diferenças significativas. 
Atividade específica de quitinase com aplicação de AS $(p<0,05)$.

\begin{tabular}{lcccc|ccc|ccc}
\hline & \multicolumn{5}{c}{ 4 SAP } & \multicolumn{3}{c|}{ 6 SAP } & \multicolumn{3}{c}{8 SAP } \\
\hline Trat./interação & GL & QM & F & Pr $>$ F & QM & F & Pr $>$ F & QM & F & Pr>F \\
\hline Fungo & 1 & 0,480 & 31,34 & $\mathbf{0 , 0 0 0}$ & 0,102 & 10,05 & $\mathbf{0 , 0 0 4}$ & 0,023 & 0,91 & 0,350 \\
AS & 1 & 0,090 & 5,89 & $\mathbf{0 , 0 2 3}$ & 0,001 & 0,11 & 0,742 & 0,089 & 3,43 & $\mathbf{0 , 0 7 6}$ \\
P (fósforo) & 1 & 0,016 & 1,06 & $0,314 \mid 0,000$ & 0,01 & $0,930 \mid 0,000$ & 0,03 & 0,854 \\
Fungo/AS & 1 & 0,006 & 0,39 & $0,535 \mid 0,000$ & 0,00 & 0,985 & 0,073 & 2,81 & 0,106 \\
Fungo/P & 1 & 0,013 & 0,89 & $0,355 \mid 0,047$ & 4,64 & $\mathbf{0 , 0 4 1}$ & 0,286 & 11,02 & $\mathbf{0 , 0 0 2}$ \\
AS/P & 1 & 0,004 & 0,26 & 0,611 & 0,005 & 0,47 & 0,501 & 0,126 & 4,85 & $\mathbf{0 , 0 3 7}$ \\
Fungo/AS/P & 1 & 0,043 & 2,84 & 0,104 & 0,000 & 0,00 & 0,986 & 0,005 & 0,20 & 0,657
\end{tabular}

Os valores em negrito representam diferenças significativas.

Caracterização isoenzimática de quitinase em géis de poliacrilamida com aplicação de AS.

\begin{tabular}{lccc}
\hline Tratamento & 4 SAP & 6 SAP & 8 SAP \\
\hline Ni BP & 34 & 32 & 38 \\
Ni AP & 25 & 22 & 78 \\
Gc BP & 75 & 62 & 103 \\
Gc AP & 58 & 82 & 127 \\
Ni AS BP & 54 & 57 & 58 \\
Ni AS AP & 13 & 35 & 69 \\
Gc AS BP & 50 & 47 & 77 \\
Gc AS AP & 48 & 45 & 116 \\
\hline
\end{tabular}

Média de 3 análises densitométricas independentes. 
Atividade específica de quitinase com aplicação de FOR $(\mathfrak{p}<0,05)$.

\begin{tabular}{|c|c|c|c|c|c|c|c|c|c|c|}
\hline \multirow[b]{2}{*}{ Trat./interação } & \multirow[b]{2}{*}{ GL } & \multicolumn{3}{|c|}{$4 \mathrm{SAP}$} & \multicolumn{3}{|c|}{$6 \mathrm{SAP}$} & \multicolumn{3}{|c|}{$8 \mathrm{SAP}$} \\
\hline & & $\mathrm{QM}$ & $\mathrm{F}$ & $\operatorname{Pr}>\mathrm{F}$ & $\mathrm{QM}$ & $F$ & $\operatorname{Pr}>F$ & $\mathrm{QM}$ & $\mathrm{F}$ & $\operatorname{Pr}>\mathrm{F}$ \\
\hline Fungo & 1 & 0,180 & 5,04 & 0,034 & 0,012 & 0,76 & 0,392 & 0,104 & 4,55 & 0,043 \\
\hline FOR & 1 & 0,061 & 1,72 & 0,202 & | 0,047 & 2,90 & 0,102 & | 0,458 & 19,93 & 0,001 \\
\hline P (fósforo) & 1 & 0,000 & 0,01 & 0,941 & 0,006 & 0,35 & $0,557 \mid$ & $\mid 0,013$ & 0,57 & 0,456 \\
\hline Fungo/FOR & 1 & 0,061 & 1,72 & 0,202 | & 0,046 & 2,80 & $0,107 \mid$ & $\mid 0,010$ & 0,44 & 0,512 \\
\hline Fungo/P & 1 & 0,135 & 3,79 & 0,063 & | 0,047 & 2,90 & 0,102 & |0,193 & 8,42 & 0,001 \\
\hline FOR/P & 1 & 0,130 & 3,64 & 0,068 & $\mid 0,023$ & 1,45 & $0,240 \mid$ & $\mid 0,044$ & 1,92 & 0,178 \\
\hline Fungo/FOR/P & 1 & 0,064 & 1,82 & 0,190 & $\mid 0,000$ & 0,00 & 0,989 & $\mid 0,028$ & 1,23 & 0,279 \\
\hline
\end{tabular}

Os valores em negrito representam diferenças significativas.

Caracterização isoenzimática de quitinase em géis de poliacrilamida com aplicação de FOR.

\begin{tabular}{lccc}
\hline Tratamento & 4 SAP & 6 SAP & 8 SAP \\
\hline Ni BP & 42 & 38 & 54 \\
Ni AP & 27 & 39 & 112 \\
Gc BP & 54 & 71 & 119 \\
Gc AP & 77 & 88 & 139 \\
Ni FOR BP & 131 & 66 & 88 \\
Ni FOR AP & 75 & 68 & 112 \\
Gc FOR BP & 135 & 71 & 97 \\
Gc FOR AP & 60 & 68 & 138
\end{tabular}

Média de 3 análises densitométricas independentes. 
Atividade específica de catalase com aplicação de AS $(p<0,05)$.

\begin{tabular}{lcccc|ccc|ccc}
\hline & \multicolumn{4}{c}{ 4 SAP } & \multicolumn{3}{|c|}{ 6 SAP } & \multicolumn{3}{c}{ 8 SAP } \\
\hline Trat./interação & GL & QM & F & Pr>F & QM & F & Pr>F & QM & F & Pr>F \\
\hline Fungo & 1 & 0,001 & 13060 & $\mathbf{0 , 0 0 0}$ & 0,000 & 8296 & $\mathbf{0 , 0 0 0}$ & 0,000 & 1183,1 & $\mathbf{0 , 0 0 0}$ \\
AS & 1 & 0,000 & 5297 & $\mathbf{0 , 0 0 0}$ & 0,000 & 5568 & $\mathbf{0 , 0 0 0}$ & 0,000 & 102,7 & $\mathbf{0 , 0 0 0}$ \\
P (fósforo) & 1 & 0,000 & 487 & $\mathbf{0 , 0 0 0}$ & 0,000 & 7568 & $\mathbf{0 , 0 0 0}$ & 0,000 & 2909,1 & $\mathbf{0 , 0 0 0}$ \\
Fungo/AS & 1 & 0,000 & 5830 & $\mathbf{0 , 0 0 0}$ & 0,000 & 7246 & $\mathbf{0 , 0 0 0}$ & 0,000 & 70,7 & $\mathbf{0 , 0 0 0}$ \\
Fungo/P & 1 & 0,000 & 39 & $\mathbf{0 , 0 0 0}$ & 0,000 & 7167 & $\mathbf{0 , 0 0 0}$ & 0,000 & 412,5 & $\mathbf{0 , 0 0 0}$ \\
AS/P & 1 & 0,000 & 2 & 0,138 & 0,000 & 8858 & $\mathbf{0 , 0 0 0}$ & 0,000 & 510,0 & $\mathbf{0 , 0 0 0}$ \\
Fungo/AS/P & 1 & 0,000 & 40 & $\mathbf{0 , 0 0 0}$ & 0,000 & 6912 & $\mathbf{0 , 0 0 0}$ & 0,000 & 1,5 & 0,231 \\
\hline
\end{tabular}

Os valores em negrito representam diferenças significativas.

Caracterização isoenzimática de catalases em géis de poliacrilamida com aplicação de AS.

\begin{tabular}{lcrr}
\hline Tratamento & \multicolumn{1}{c}{ 4 SAP } & \multicolumn{1}{c}{6 SAP } & \multicolumn{1}{c}{8 SAP } \\
\hline Ni BP & nd & 2679265 & nd \\
Ni AP & nd & 3298 & nd \\
Gc BP & 7710094 & 5071019 & 2122868 \\
Gc AP & 5487757 & 3347118 & 46843 \\
Ni AS BP & 1319253 & 2117296 & 3840 \\
Ni AS AP & 686953 & 1552008 & 361822 \\
Gc AS BP & 10520341 & 1354100 & 338823 \\
Gc AS AP & 3641899 & 8314958 & 6985536 \\
\hline
\end{tabular}

Média de 3 análises densitométricas independentes. 
Atividade específica de catalase com aplicação de FOR $(\mathrm{p}<0,05)$.

\begin{tabular}{|c|c|c|c|c|c|c|c|c|c|c|}
\hline \multirow[b]{2}{*}{ Trat./interação } & \multirow[b]{2}{*}{$\mathrm{GL}$} & \multicolumn{3}{|c|}{4 SAP } & \multicolumn{3}{|c|}{$6 \mathrm{SAP}$} & \multicolumn{3}{|c|}{8 SAP } \\
\hline & & QM & $\mathrm{F}$ & $\operatorname{Pr}>F$ & QM & $\mathrm{F}$ & $\operatorname{Pr}>F$ & QM & $\mathrm{F}$ & $\operatorname{Pr}>F$ \\
\hline Fungo & 1 & 0,000 & 4132 & 0,000 & 0,000 & 252 & 0,000 & 0,000 & 1199 & 0,000 \\
\hline FOR & 1 & 0,000 & 407 & 0,000 & 0,000 & 3972 & 0,000 & 0,000 & 52 & 0,000 \\
\hline$P$ (fósforo) & 1 & 0,000 & 9 & 0,006 & 0,000 & 4840 & 0,000 & 0,000 & 365 & 0,000 \\
\hline Fungo/FOR & 1 & 0,000 & 699 & 0,000 & 0,000 & 96 & 0,000 & 0,000 & 65 & 0,000 \\
\hline Fungo/P & 1 & 0,000 & 39 & 0,000 & 0,000 & 163 & 0,000 & 0,000 & 114 & 0,000 \\
\hline FOR/P & 1 & 0,000 & 423 & 0,000 & 0,000 & 5903 & 0,000 & 0,000 & 147 & 0,000 \\
\hline Fungo/FOR/P & 1 & 0,003 & 38 & 0,000 & 0,000 & 126 & 0,000 & 0,000 & 116 & 0,000 \\
\hline
\end{tabular}

Os valores em negrito representam diferenças significativas.

Caracterização isoenzimática de catalases em géis de poliacrilamida com aplicação de FOR.

\begin{tabular}{lcrr}
\hline Tratamento & \multicolumn{1}{c}{ 4 SAP } & \multicolumn{1}{c}{ 6 SAP } & \multicolumn{1}{c}{ 8 SAP } \\
\hline Ni BP & nd & 2894254 & nd \\
Ni AP & nd & 3632 & nd \\
Gc BP & 9263210 & 5562409 & 1168618 \\
Gc AP & 6500151 & 3784418 & 23404 \\
Ni FOR BP & 149587 & 1411113 & 24036 \\
Ni FOR AP & 1047675 & 8218542 & 4828903 \\
Gc FOR BP & 9937765 & 982008 & 65259 \\
Gc FOR AP & 9082744 & 4284531 & 2854647 \\
\hline
\end{tabular}

Média de 3 análises densitométricas independentes. 